\title{
Pre-1.91 Ga deformation and metamorphism in the Palaeo- proterozoic Vammala Migmatite Belt, southern Finland, and implications for Svecofennian tectonics
}

\author{
R. W. Roye Rutland ${ }^{\mathrm{I})^{*}}$, Ian S. Williams ${ }^{\mathrm{I}}$, and Kalevi Korsman ${ }^{2)}$ \\ 1) Research School of Earth Sciences, Australian National University, Canberra, ACT \\ 0200, Australia \\ 2) Pietiläntie 6 A2, 03100 Nummela, Finland
}

\begin{abstract}
A metamorphic event in the Vammala Migmatite Belt (VMB) at $\sim 1.92 \mathrm{Ga}$, revealed by SHRIMP $U-\mathrm{Pb}$ analyses of both zircon overgrowths and monazite, is interpreted as post-depositional and is correlated with the development of the early high-grade schistosity. Neither this Early Svecofennian deformation and metamorphism, nor the associated complex folding, is present in the overlying Tampere Schist Belt (TSB) sequence, consistent with the VMB being part of a pre- I.9I Ga basement complex. The $\sim 1.92$ Ga event provides a maximum deposition age for the TSB, confirming earlier age estimates. Earlier stratigraphic correlations between parts of the VMB and TSB, and associated tectonic interpretations, can no longer be sustained. The crustal thickening seen in the VMB, and previously attributed to arc accretion at $\sim 1.89 \mathrm{Ga}$, is now attributed to accretion of a large Svionian marginal basin during the 'Early Svecofennian' orogenic phase at $\sim 1.92 \mathrm{Ga}$. This is of similar age to the deformation and metamorphism associated with collision in the Lapland-Kola Orogen to the north of the Karelian Province. The well-known post-TSB orogenic phase was also identified in the VMB by a monazite age of I $88 \mid \pm 6 \mathrm{Ma}$. A granitoid intrusion gave an emplacement age of I $888 \pm 5 \mathrm{Ma}$, comparable to the age of granitoid clasts in the upper part of the TSB succession.

The detrital zircon data are interpreted to suggest that deposition of the precursor VMB sediments probably took place soon after an earlier pre-depositional metamorphism at $\sim 1.98 \mathrm{Ga}$, which affected igneous source complexes dated at $\sim 1.99 \mathrm{Ga}$ and $\sim 2.0 \mathrm{I} \mathrm{Ga}$. Mafic rocks in the southern part of the VMB, and probably also the Haveri basalts, represent a renewed episode of extensional magmatism, which might correlate with the 1.96-1.95 Ga Jormua and Outokumpu ophiolites. A pre-1.96 Ga older stage basin has an expression in Sweden and complexes of similar age occur in the concealed Palaeoproterozoic basement south of the Gulf of Finland. Similar rocks, deformed and metamorphosed before $\sim 1.96 \mathrm{Ga}$, might be present beneath the Central Finland granitoid complex and the late Svecofennian granite-migmatite zone, and were possibly more local sources for both the younger stage Svionian basin sediments and the post-1.9I Ga Bothnian Basin sediments.

The TSB and other post-accretionary volcanic sequences, and the associated plutonism, are interpreted to reflect a $\sim 40$ m.y. extensional period, inboard of the contemporaneous active margin, between orogenic phases at $\sim 1.92 \mathrm{Ga}$ and $\sim 1.88 \mathrm{Ga}$. This interpretation provides a more satisfactory explanation of the major heat input to the crust over a very wide area than does the arc accretion hypothesis. The tectonic evolution of the Svecofennian Province has strong similarities to that of the Palaeozoic Lachlan Fold Belt in eastern Australia.
\end{abstract}

Key words: metasedimentary rocks, migmatites, gneisses, deformation, metamorphism, tectonics, Svecofennian Domain, absolute age, U/Th/Pb, zircon, monazite, Palaeoproterozoic, Vammala, Tampere, Finland

* Corresponding author e-mail: roye.rutland@anu.edu.au 


\section{Introduction}

The Svecofennian Province of the Fennoscandian Shield is exposed in an approximately triangular area about $1,000 \mathrm{~km}$ on a side adjacent to the Archaean Karelian Province (Fig. 1). Similar Palaeoproterozoic rocks are also preserved beneath the Phanerozoic cover of the East European Platform (Gorbatschev \& Bogdanova, 1993). East of the post-1.85 Ga igneous complexes on its western margin, the Svecofennian Province proper is dominated by intrusive granitoids associated with more limited volcanic sequences and extensive migmatite complexes of which the Vammala Migmatite Belt (VMB) is one of the best known (Fig. 2; Kilpeläinen, 1998). Most of the volcanic and plutonic rocks were formed between 1.90 and 1.87 Ga (e.g. Huhma, 1986; Patchett \& Arndt, 1986; Gaál \& Gorbatschev, 1987). The volcanic sequences (including those of the Tampere Schist Belt (TSB) adjacent to the VMB, Fig. 2) have been interpreted as having island arc affinities, and models have been developed in which island arcs, formed over a series of subduction zones, have been progressively accreted to the Karelian craton (e.g. Park, 1985; Ekdahl, 1993; Lahtinen, 1994; Nironen, 1997). The province has come to be widely accepted as an example of rapid crustal growth by arc accretion.

Two principal episodes of accretion have been proposed in Finland: at $-1.91-1.90 \mathrm{Ga}$, east of the Central Finland Granitoid Complex, and at $-1.89-1.88 \mathrm{Ga}$, south of that complex (Lahtinen, 1994). The arc-accretionary model is reflected in the terminology of the 1: 1000000 Bedrock map of Finland (Korsman et al., 1997): only the "Primitive arc complex of central Finland (1.93-1.87 Ga)", immediately adjacent to the Archaean of the Karelian Domain (C in Fig. 1; the Savo Belt in Fig. 2), is identified as older than $1.90 \mathrm{Ga}$ (see also Korsman et al., 1999). The VMB occupies a critical position between the "Accretionary arc complex of southern Finland (1.90-1.82 Ga)" and the "Accretionary arc complex of central and western Finland (1.90-
$1.87 \mathrm{Ga}$ )" (A and B in Fig.1), both of which have been considered to contain exotic terranes, mainly on the basis of geochemical and detrital zircon data (e.g. Lahtinen, 1994; Rämö et al., 2001; Lahtinen et al., 2002). The migmatites in the north of the VMB have been interpreted as a fore arc (Lahtinen 1996, p. 43), or accretionary complex (Kähkönen, 1999, pp. 26-27) closely related in time to the TSB, which was inferred to have been formed above a northward dipping subduction zone. Lahtinen (1994, p. 95) and Kähkönen et al. (1994, pp. 44-45, Fig.1) also suggested the presence of a suture in the southern part of the VMB.

Nonetheless the arc-accretion hypothesis does not readily explain the ubiquitous occurrence of plutonic rocks of similar age throughout the Svecofennian Province, nor their extension far into the NW Karelian province. It has been recognised that the Svecofennian province is unusual compared with Phanerozoic arc complexes, and that the evolved nature of the volcanics requires a pre-1.9 Ga history (Kähkönen et al., 1989, p. 40; Nironen \& Kähkönen, 1994). Evidence for a pre-1.9 Ga component in both the volcanic and plutonic $1.90-1.87$ Ga suites has steadily accumulated (e.g. Lahtinen, 1994; Lahtinen \& Huhma, 1997; Vaasjoki \& Huhma, 1999, for Finland; Valbracht et al., 1994; Andersen \& Sundvoll 1995; Claesson \& Lundqvist 1995; Billström \& Weihed, 1996; Lundqvist et al., 1998, for Sweden).

It is also recognised that the pre-Svecofennian ocean opened by $1.95 \mathrm{Ga}$ (preferred by Nironen, 1997) and possibly by $2.1 \mathrm{Ga}$ (Lahtinen, 1994) or even earlier (Rutland et al., 2001b). Studies of detrital zircons in post-1.9 Ga metasediments have revealed that source areas with ages of 2.1-1.9 Ga were available for erosion -1.9 Ga ago (Huhma et al., 1991; Claesson et al., 1993; Welin et al., 1993), although no such areas could be identified. Lundqvist et al. (1998) considered that, in Sweden, sediments were deposited in the Bothnian Basin (Fig. 1) over an 
extended period from before $1.95 \mathrm{Ga}$ to at least $1.87 \mathrm{Ga}$. They recognised several phases of granitic magmatism, but no accompanying deformation or interruptions to sedimentation during that period. Such evidence is not readily reconciled with an arc accretion process.

Lahtinen \& Huhma (1997) argued that the isotopic and geochemical data for the Central Finland Granitoid Complex (CFGC) and TSB (Fig. 2) indicated the presence of an evolved thick crust at $2.0 \mathrm{Ga}$. They proposed a tentative model involving the presence of a continental nucleus under the CFGC, surrounded by more juvenile island arc accretions. They inferred that this older crust formed the basement to the oldest volcanic rocks (the Haveri Formation) in the TSB. Kähkönen (1999, p. 27) remarks that no preserved rocks of the proposed -2.0 Ga crust are known in central Finland. Nevertheless, the VMB remains a potential candidate for an older basement (cf. Kähkönen, 1996).

Early in work on the Tampere area it was suggested that an older Svionian Formation was separated from a younger Bothnian Formation by a great unconformity (Sederholm, 1897; 1931), i.e. the VMB formed basement to the TSB. This basement-cover hypothesis was abandoned by later workers, who posited the stratigraphic equivalence of the TSB and VMB (Kilpeläinen, 1998, p. 7, and references therein). However, the Sederholm hypothesis has never been convincingly refuted (Nironen, 1989, p. 36; section 2.2 below), and the basement-cover hypothesis has recently been revived to explain relations between the migmatite complex of the Swedish Robertsfors Group and the Skellefte volcanic belt (Fig. 2). Rutland et al. (2001a and $2001 \mathrm{~b})$ argued that the early $\left(\mathrm{D}_{1}\right)$ deformation and metamorphism in the Robertsfors Group took place before deposition of the Skellefte sequence (i.e. before $\sim 1.9 \mathrm{Ga}$ ). They also suggested that pre-1.9 Ga complexes, forming basement to the volcanic sequences, are widespread in the Svecofennian Province (see Fig. 2). This led to an alternative plate tectonic model in which it was proposed that the basement com- plexes were initiated as the fill of a large marginal basin, when the contemporaneous active margin lay to the SW of the exposed Svecofennian Province (cf. Hietanen, 1975). Closure of that basin was considered to be responsible for the principal episode of accretion and crustal thickening. It was therefore proposed to restrict the term Bothnian Basin to the sequences deposited after the $\mathrm{D}_{1}$ deformation and to apply Sederholm's term 'Svionian' to the pre- $\mathrm{D}_{1}$ sequences.

Dating the main period of deformation and metamorphism is the key to testing these two models. If the Svecofennian was formed by arc accretion, then the main deformation and metamorphism should have accompanied or followed the deposition of the volcanic sequences (e.g. at $\sim 1.89-1.88 \mathrm{Ga}$ for the VMB, Lahtinen, 1994). If it formed by marginal basin accretion, the main deformation and metamorphism should have preceded deposition of those sequences, i.e. before $\sim 1.90-1.91 \mathrm{Ga}$. The present paper tests these alternative hypotheses for the VMB in the classical Tampere area.

\section{The Tampere Area}

The Tampere area lies on the southern margin of the 'Accretionary arc complex of central and western Finland', as shown on the 1: 1000000 Bedrock map of Finland (Korsman et al., 1997; see Figs. 1 \& 2). The Tampere Schist Belt (TSB) forms an asymmetric, upright, synclinal structure, about $20 \mathrm{~km}$ or less in width (Simonen, 1953; Nironen, 1989a), immediately south of the Central Finland Granitoid Complex (CFGC; see Figs. $2 \& 3$ ), and north of the Vammala Migmatite Belt (VMB). The main belt of volcanic rocks is less than $10 \mathrm{~km}$ wide and about $100 \mathrm{~km}$ long, while the TSB as a whole is about $160 \mathrm{~km}$ long.

The predominant suite of weakly foliated granodiorites, tonalites and quartz diorites in the CFGC has been allocated on the map to the 1.89-1.88 Ga interval, and similar rocks occur in the TSB and VMB. Voluminous unfoliated granites in the CFGC, have been allocated to 


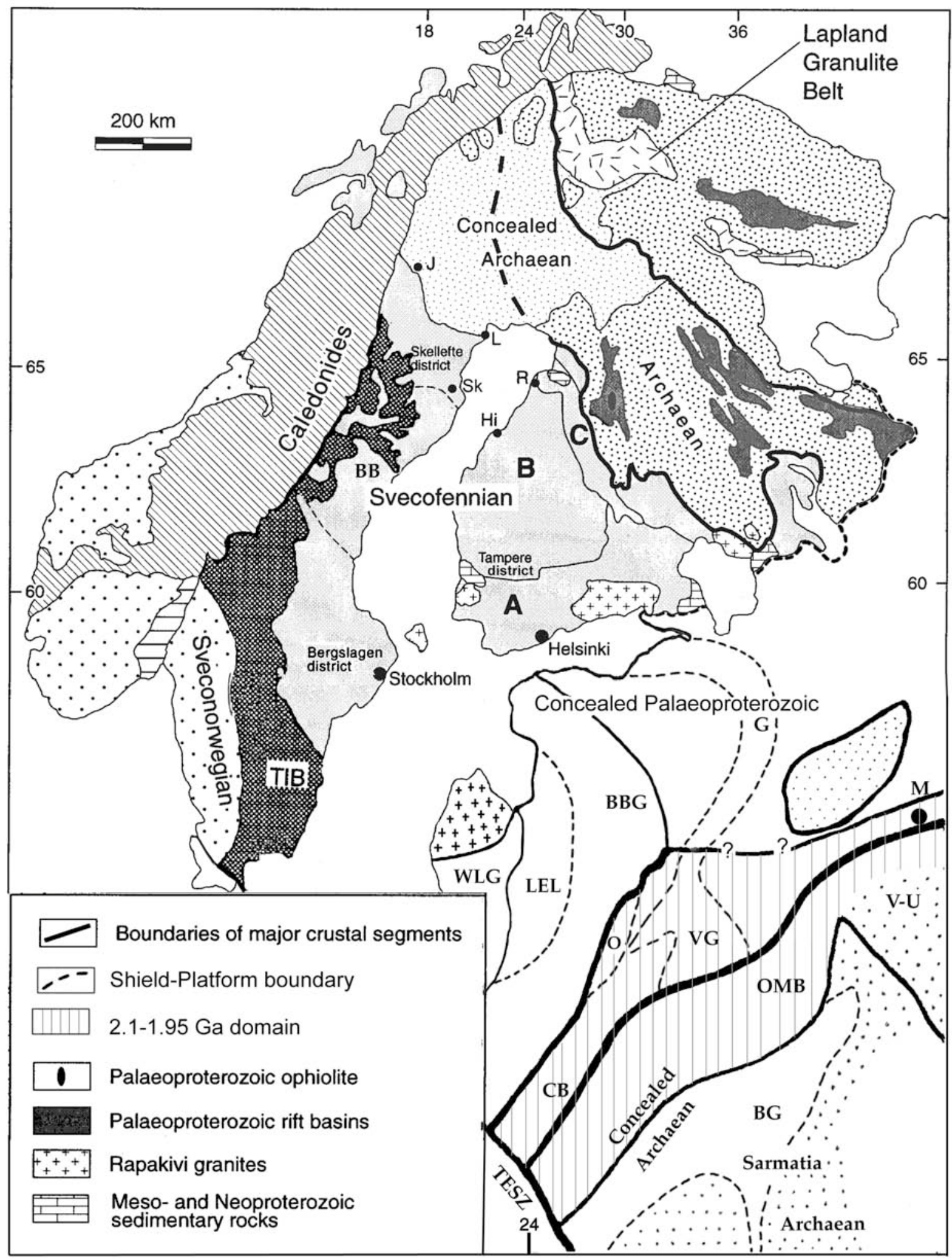


Fig. I. Regional setting and main elements of the Svecofennian orogenic province, and of the concealed Palaeoproterozoic domains in the basement of the East European Craton (modified after Gee and Zeyen, 1996, and Claesson et al., 200I).

In the Svecofennian Province: Areas A, B and C are from Korsman et al., 1997:

$\mathrm{A}$, Accretionary arc complex of southern Finland (I.90-I.87 Ga)

$\mathrm{B}$, Accretionary arc complex of central and western Finland (I.90-I.87 Ga);

C, Primitive arc complex of central Finland (I.93-I.87 Ga).

Note that the Bothnian Basin has usually been considered to extend over most of area B, which is now largely occupied by granitic rocks. TIB, Transscandinavian Igneous Belt ( I.85-I.65 Ga); Hi, Himanka; J, Jokkmokk; L, Luleå; R, Raahe; Sk, Skellefteå.

In the East European Craton, WLG, West Lithuanian Granulite Domain; LEL, Latvian-East Lithuanian Belt; BBG, Belarus-Baltic Granulite Belt; G, granulite belt, possible northward extension of VG, Vitebsk Granulite Domain; CB, Central Belarus Belt; O, Okolovo Volcanic Belt ( 2.0-1.98 Ga); OMB, Osnitsk-Mikashevichi Igneous Belt (2.0-1.95 $\mathrm{Ga})$; BG, Bragin Granulite Domain( 2.3-2.I Ga);V-U,Volgo-Uralia Archaean Province;TESZ, Trans-European Suture Zone; M, Moscow.

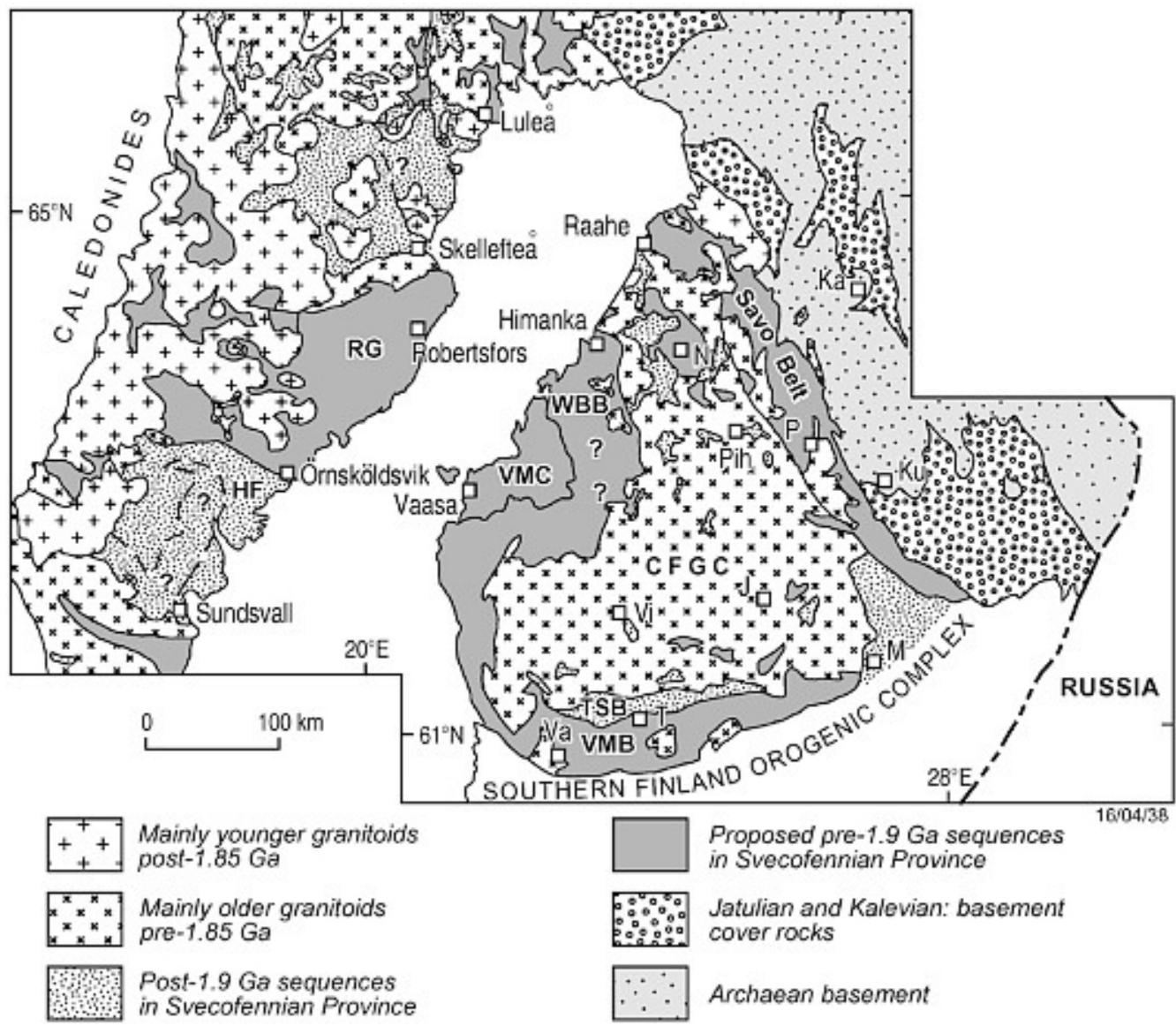

Fig. 2. Geological map showing outcrops of Kalevian rocks on the SW margin of the Karelian Province and their proposed correlatives in the Svecofennian Province (modified after Rutland et al., 200 Ib, Fig. 6). H, Himanka; M, Mikkeli; N, Nivala; Pih, Pihtipudas; P, Pyhajärvi; R, Robertsfors; T, Tampere; HF, Härnö Formation; RG, Robertsfors Group;TSB, Tampere Schist Belt; VMB, Vammala migmatite Belt; VMC, Vaasa Migmatite Complex; WBB, Western Bothnian Belt; CFGC, Central Finland Granitoid Complex. Note that the pre-I.9 Ga metamorphic complexes, other than the Savo Belt, were previously considered to be part of the Bothnian Basin but are here distinguished as the Svionian Basin. 
$-1.88 \mathrm{Ga}$. Some younger, more equidimensional granite plutons, dated at $1.88-1.87 \mathrm{Ga}$, occur immediately north of, and within, the TSB (Fig. 3; see Nironen et al., 2000; Rämö et al., 2001). Both of these granite types occur across the whole width of the CFGC (nearly $300 \mathrm{~km}$ ) but they are not mapped within the VMB.

South of the VMB (Fig. 15), the Hämeenlinna-Somero Volcanic Belt (HSB; Hakkarainen, 1994) has similar characteristics to the TSB. Further south, the late Svecofennian granite-migmatite zone (LSGM, Ehlers et al., 1993; Väisänen \& Hölttä, 1999) is characterised by a distinctly younger $(<1.84 \mathrm{Ga})$ suite of microcline granites and associated deformation and metamorphism, superimposed on the 1.89$1.87 \mathrm{Ga}$ early plutonic rocks and on the KemiöMäntsälä volcanic belt (KMB).

\section{I.The Tampere Schist Belt}

The detailed studies of the TSB outlined below refer mainly to the main syncline on both sides of the lake north of Tampere (Fig. 3). Most of the ages quoted have been measured by IDTIMS zircon U-Pb. The stratigraphic profiles in the syncline (Kähkönen et al., 1989; Kähkönen, 1999) show an upward transition from turbidite-dominated submarine environments to volcanic-dominated, in part subaerial, environments. The turbidites below the volcanics occur mainly in the southern limb of the main syncline, where they are named the Myllyniemi formation (Fig. 3). The youngest detrital zircons from two samples (Huhma et al., 1991; Claesson et al., 1993) indicate maximum deposition ages of "about 1.92-1.91 Ga" (Lahtinen et al., 2002).

The lower volcanics, intercalated in the upper part of the turbidite succession, are mostly felsic. Kähkönen (1994) makes some analogy with Stromboli shoshonitic lavas. Localities in the $\mathrm{N}$ limb of the main syncline give zircon ages of $1904 \pm 4$ and $1898 \pm 4 \mathrm{Ma} ;-1.89 \mathrm{Ga}$ (Kähkönen et al., 1989). A unit considered to represent the lowermost major volcanic unit among the tur- bidites in the southern limb has yielded a SIMS age of $1898 \pm 8 \mathrm{Ma}$, and a high-K rhyolite near the top of this succession has given a TIMS age of $1892 \pm 3 \mathrm{Ma}$ (Kähkönen et al., 2004).

The greywackes of the Tervakivi Formation, above this rhyolite, terminate the previous upward-fining trend in the sediments. One conglomerate (the Veittijärvi conglomerate) contains plutonic clasts dated at $-1.88-1.89 \mathrm{Ga}$ (Nironen, 1989b), and provides evidence of syn-depositional uplift and erosion. The deposition age of this conglomerate must lie between the age of the underlying rhyolite $(1892 \pm 3 \mathrm{Ma})$ and the age of overlying volcanics in the core of the main syncline $(1889 \pm 5 \mathrm{Ma}$, Kähkönen et al., 1989). The latter date also further constrains the age of the intrusion from which the granitoid pebbles originated. Significant, and probably extensional, tectonic activity is also indicated by the change to basalts and andesites in the upper volcanics; and by the substantial thickness of arenites (Kalkku and Mauri arenites) and overlying mudrocks in the upper parts of the succession (Kähkönen, 1999, pp. 24-25). According to Kähkönen (op. cit) the arenites were derived from a source similar to high- $\mathrm{K}$ rhyolites at the top of the lower volcanics, implying that such volcanics were volumetrically more important than now seen, and emphasising the importance of the syn-depositional erosion.

Although the presence of conglomerates with granitoid pebbles indicates tectonic activity during deposition, the main compressional deformation of the TSB by folding appears to postdate the whole stratigraphic succession (Nironen, 1989a). This local $F_{1}$, and associated structures, are identified with the prefix ' $\mathrm{T}$ ' below to distinguish them from deformation episodes in the VMB, which are identified with the prefix ' $\mathrm{V}$ '. The main $\mathrm{TF}_{1}$ folds are upright and somewhat asymmetric with a near vertical axial plane schistosity, $\mathrm{TS}_{1}$. No earlier schistosity is observed, although the migmatites of the VMB to the south do provide evidence of an older deformational-metamorphic event (op. cit. p. 34).

The gross crosscutting relations of the plu- 


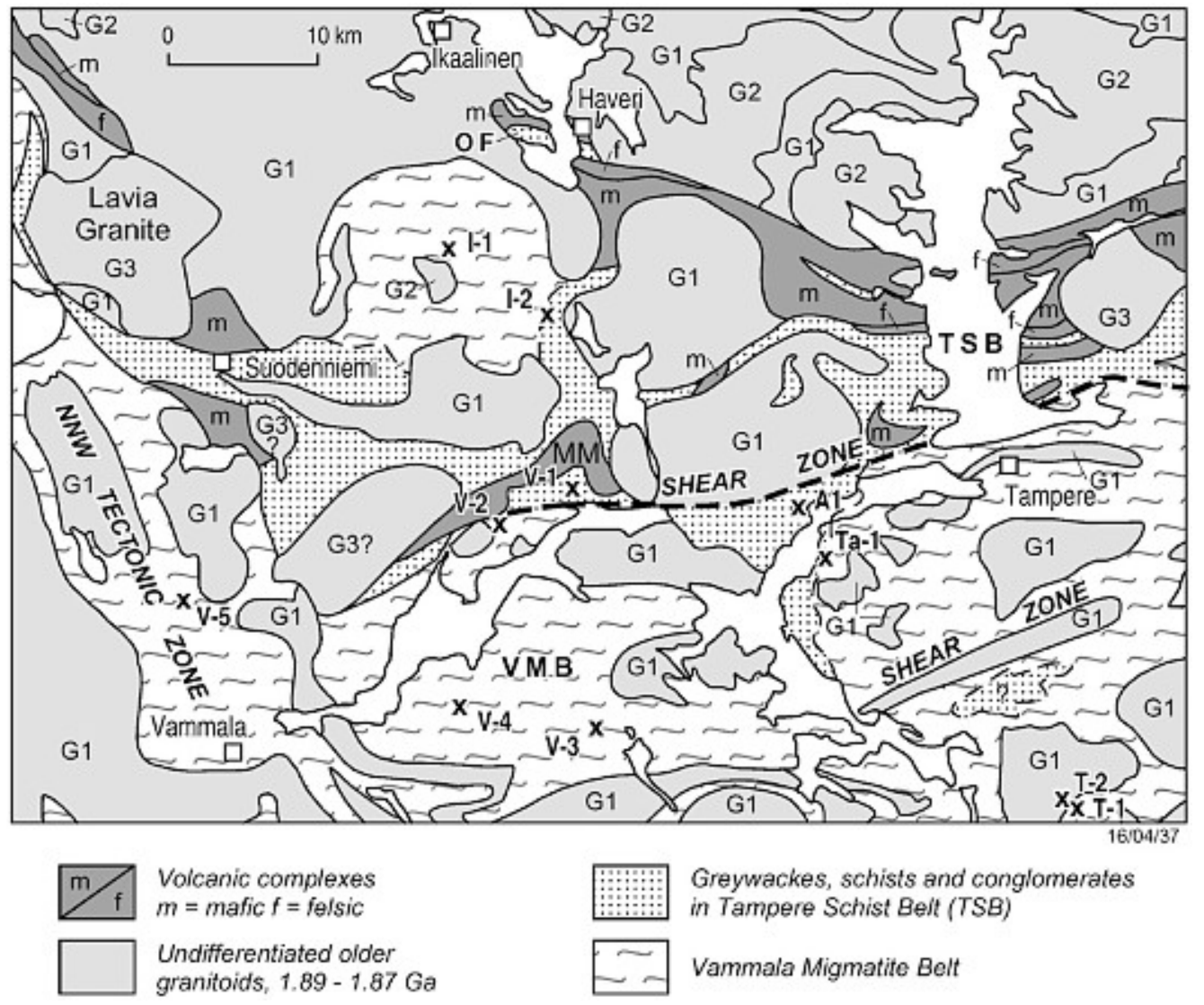

Fig. 3. Geological map of part of the Tampere and Vammala belts (modified after Korsman et al., 1997), also showing key localities (see text). TSB, Tampere Schist Belt; MM, Mauri Meta-arkose;VMB,Vammala Migmatite Belt; OF, Osara Formation; GI, granodiorite, tonalite and quartz diorite (I.89-I.88 Ga); G2, granite ( I.88 Ga); G3, granite (I.88I.87 Ga). Note (I) the inferred post-TSB shear zone in VMB, parallel to southern margin of TSB (cf. Fig. 5) (2) that the Haveri basalts and the overlying Osara formation are shown as part of the TSB in accordance with published views. As discussed in the text, allocation to the VMB is here preferred.

tons in the central TSB suggest that they were emplaced late in the deformation history. However, following detailed study of the structural relationships, Nironen (1989b) concluded that the plutons were syn-tectonic with $\mathrm{TD}_{1}$. The measured ages of these plutons range between $\sim 1.88$ and $1.91 \mathrm{Ga}$, possibly because of the presence of some inherited zircon, and an age of $\sim 1.88$ Ga can be inferred for emplacement and folding. The little-deformed Lavia porphyritic granite (Fig. 3), a granitic body that has been grouped with the post-kinematic suite in the CFGC, has been dated at $1870 \pm 4 \mathrm{Ma}$ (Nironen et al., 2000).

Prograde metamorphism, with the crystallization of staurolite, garnet and andalusite, is closely associated with $\mathrm{TD}_{1}$. Andalusite continued to crystallise after the deformation, when sillimanite also began to crystallise, indicating that progressive metamorphism continued after the deformation. Pressure has been estimated at 3-4 kbar with peak temperatures of $470^{\circ} \mathrm{C}$ in the central parts and $570^{\circ} \mathrm{C}$ in the marginal parts of the Tampere syncline (Kilpeläinen et 
al., 1994). Thus, although the precise relations between them are not clear, the metamorphism, deformation and granitoid intrusion are closely related in time and constrained between $\sim 1.89$ and $1.87 \mathrm{Ga}$.

\subsection{The Vammala Migmatite Belt and relations to the TSB}

The belt of migmatised mica gneisses and schists south of Tampere (Figs. 2 \& 3) trends E$\mathrm{W}$ and is up to $50 \mathrm{~km}$ wide. It is part of a belt extending to east and west that has been given various names in the literature, including Vammala Migmatite Belt (Kähkönen et al., 1994), Pori-Vammala-Mikkeli Migmatite Zone (Kilpeläinen, 1998), Mica gneiss-migmatite Belt (Lahtinen, 1994; 1996), Psammitic migmatite zone (Korsman et al., 1999), Tonalite Migmatite Zone (Koistinen et al., 1996), and Tonalite-Trondhjemite Migmatite Belt (Mouri et al., 1999). The name Pirkanmaa Belt has also recently been recommended (Nironen et al., 2002) for an extensive lithological-geographical area, the limits of which have not been fully defined. The belt is here considered to be one part of widespread pre-1.91 Ga metamorphic complexes in the Svecofennian domain (Fig.1). We therefore revert to the geographically qualified name, Vammala Migmatite Belt (VMB), to distinguish the segment south of the TSB.

Geochemical studies (Lahtinen, 1996) show that the VMB has distinctive sediments with massive psammites, and some conglomerates, in the NE, and pelites and black schists in the SW. Other greywackes in the VMB differ from those in the TSB in having a greater mafic component. Volcanic rocks occur mainly in the southern part of the $\mathrm{VMB}$, and are mafic with both $\mathrm{N}-\mathrm{MORB}$ and E-MORB/WPB affinities, apparently formed in a rift or marginal basin environment (op. cit. p. 61). Some granitic and mafic intrusions also indicate a WPB component (op. cit. p. 91).

Kilpeläinen $(1998$, p. 7$)$ noted that in the first half of the last century the possibility of a "great discordance" between the TSB and VMB, as proposed by Sederholm, was widely discussed. But since the stratigraphic investigations of Simonen (1953), "it has been largely accepted that the areas are not exotic relative to each other in either age or palaeogeography". Kilpeläinen et al. (1994, p. 27) state, "It was eventually concluded that the migmatite area was merely a marine part of the Tampere island arc formation, in which the metamorphic grade increases gradually from the synclinally folded Tampere schist area to the anticlinally folded Vammala migmatite area (Simonen, 1980)." Lahtinen (1996), on the basis of lithology and geochemistry, suggests broad correlations between the sediments of much of the VMB and those of the TSB.

The evidence for the stratigraphic correlation between the VMB and TSB is not conclusive, however. Simonen (1953), in reviewing earlier views critical of Sederholm's hypothesis, did not deny the existence of a sub-Bothnian unconformity but suggested (op. cit., p. 12) that it is the result of local erosion during orogenic evolution. This does not negate the possibility that the metasediments of the VMB are older than any part of the TSB. Nironen (1989, p. 36) commented that Sederholm's (1897) conclusion had not been satisfactorily refuted, and noted that nothing was known about the age of the palaeosome in the migmatites. The possibility therefore remains that the VMB is stratigraphically older than the TSB. However, the basement-cover hypothesis also suggests that the earliest deformation and metamorphism in the VMB should pre-date the TSB.

Aeromagnetic evidence, which was not available to the early workers, provides support to the basement-cover hypothesis. The volcanic sequence in the main TSB syncline shows a simple linear pattern, consistent with the observed $\mathrm{TD}_{1}$ folding. The greywackes immediately to the south lack a significant signature but are known to share the same simple folding. The south-side-up shear zone, which separates the TSB from the VMB (Fig. 3), is essentially a $\mathrm{TD}_{1}$ 
structure (Nironen, 1989a, p. 31) and there is an abrupt change to a strikingly more complex aeromagnetic pattern in the VMB. This pattern has been shown by Kilpeläinen (1998) to reflect multiple folding. Upright folds of the earliest schistosity have variable trends as a result of refolding on axes approximately parallel to the main folds of the TSB (Fig. 5).

Kilpeläinen (1998) has provided a comprehensive discussion of the structures in various sub-areas of the VMB (see Fig. 5). He notes the difficulties in making regional correlations when the intensity of deformation episodes varies and when the relative and absolute ages of peak metamorphism also vary. However, he allocated all the structures to three generations distinguished on the basis of style and superposition (op. cit., pp. 74-81):

- $\mathrm{D}_{1}$, represented throughout by a penetrative layer-parallel biotite schistosity, inferred to have been near horizontal when formed.

- $\mathrm{D}_{2}$, represented by upright, near isoclinal, macroscopic folds, responsible for the present near vertical attitude of $S_{0} / S_{1} . S_{2}$ may occur as an axial plane schistosity or as a crenulation of $S_{1}$.

- $\mathrm{D}_{3}$, represented by open upright folds and shear zones. They fall into two, probably conjugate sets, trending ENE to NE, and WNW to NW (Fig. 5).

As noted above, we now prefix ' $V$ ' to these categories. The two $\mathrm{VD}_{3}$ shear directions correspond well in trend with the $\mathrm{TS}_{1}$ schistosity, axial plane to the main post-TSB folds, and our examination of critical field evidence below suggests that their correlation is generally valid. This is in accord with the interpretation of Koistinen et al. (1996, p. 49), although Kilpeläinen (1998, Fig. 49 , p. 75 , pp. $78-79)$ correlates $\mathrm{VD}_{2}$ with the main $\left(\mathrm{TD}_{1}\right)$ folding in the TSB, as shown in Fig. 5. We suggest that problems of correlation have arisen because the above scheme, while generally applicable, is somewhat oversimplified in that new planar schistosity may develop locally dur- ing $\mathrm{D}_{3}$ as well as $\mathrm{D}_{2}$, and structures categorised as $\mathrm{D}_{2}$ may belong to two generations.

$\mathrm{TS}_{1}$ is closely related to shear zones, and layering can be transposed parallel to $\mathrm{TS}_{1}$ (Nironen, 1989a, pp. 27-31). In the VMB, the corresponding deformation appears to be concentrated in broad major shear zones trending ENE in the area south of Tampere, WNW through the Koosanmaa sub-area, and NNW through the Vammala area (compare Figs. 3 \& 5 with Fig. 4). Within these zones, and especially in the ENE zone, the granitoid intrusions are elongated parallel to the zones and to the postTSB structures (e.g. in the Stormi sub-area of Fig. 5, detailed in Kilpeläinen, 1998, Fig. 16, and in the SE corner of the Pirkkala sub-area). Folds of $\mathrm{VF}_{2}$ style may also be near parallel to the zones, perhaps as a result of rotation. Moreover, transposition of layering parallel to $\mathrm{VS}_{2}$ or $\mathrm{VS}_{3}$ may have resulted locally in such schistosity being indistinguishable from $\mathrm{VS}_{1}$. Outside the major shear zones, the granitoid intrusions are of irregular form and their contacts transect the trends of folds of $\mathrm{VF}_{2}$ style. The post-TSB deformation is represented by a $\mathrm{VS}_{3}$ crenulation cleavage (e.g. in the Myllymaa, Ellivuori and Hämeenkyrö sub-areas of Fig. 5, detailed in Kilpeläinen, 1998, Figs. 8, $12 \& 31$ ).

Peak metamorphism was considered to have occurred during $\mathrm{VD}_{1}$ (op. cit., pp. 96-97), with sillimanite, garnet and cordierite growth in appropriate lithologies. However, crystallisation of garnet always preceded that of cordierite, and cordierite often clearly post-dates the $\mathrm{VD}_{1}$ deformation, probably reflecting decompression. Metamorphism and migmatisation in the VMB has recently been dated, using several isotopic methods, at $-1.88 \mathrm{Ga}$ (Mouri et al., 1999). It was inferred (op. cit.) that these migmatites were metamorphosed at peak conditions of $700-750^{\circ} \mathrm{C}$ and $4-5 \mathrm{kbar}$, and also record a retrogressive phase involving decompression and cooling to around $500-650^{\circ} \mathrm{C}$ and 3-4 kbar, in the andalusite stability field. We argue below (section 7.4) in the light of our data, that the metamorphism dated by Mouri et al. is 


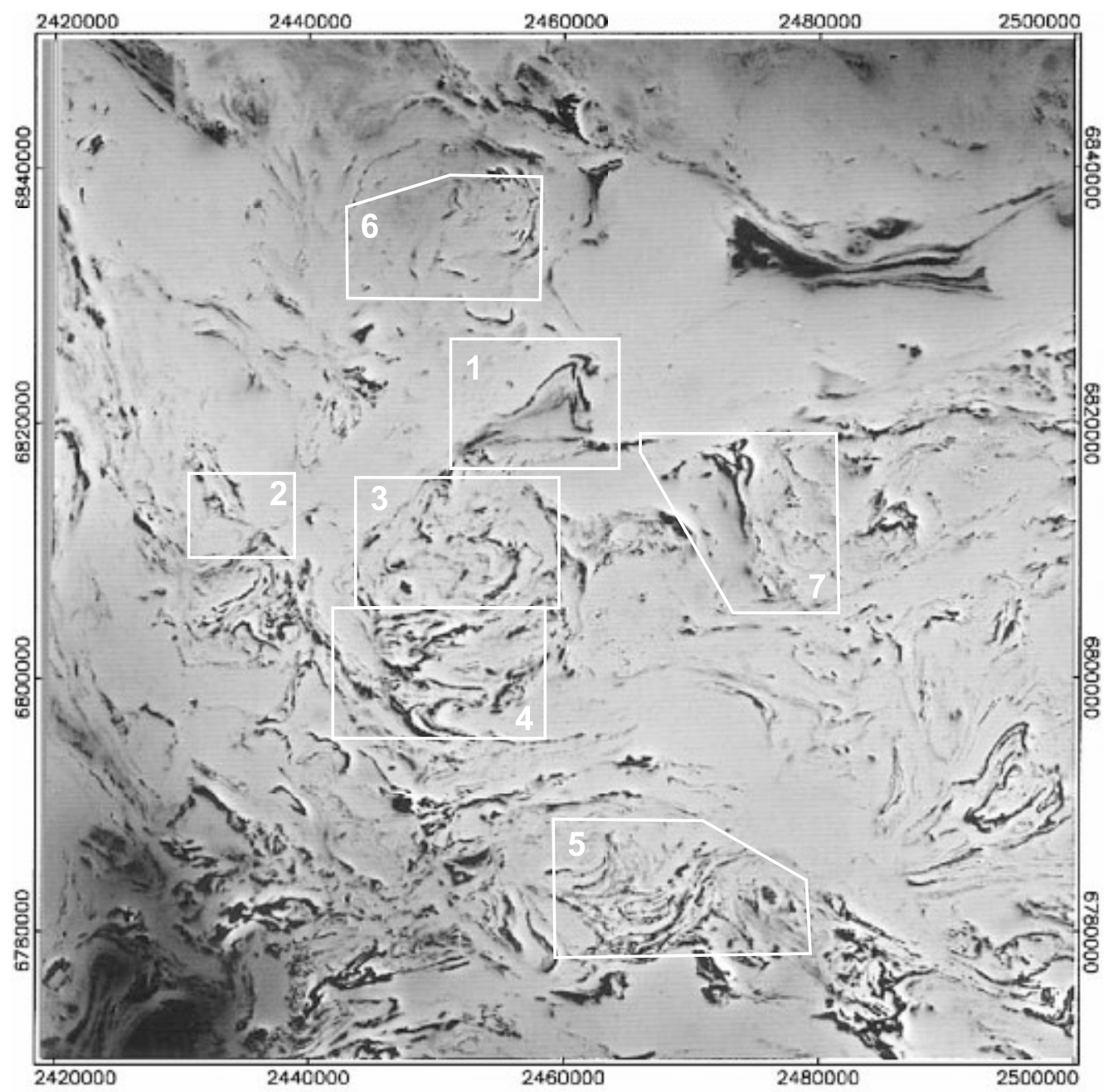

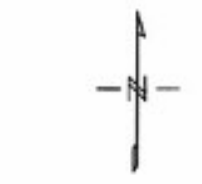

5000

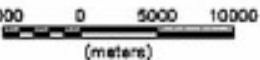

the post-TSB $\left(\mathrm{TD}_{1}\right)$ metamorphism and not the earlier $\mathrm{VD}_{1}$.

A date of $1881 \pm 4 \mathrm{Ma}$ for a quartz diorite in the central VMB has been interpreted as the age of magmatism synchronous with the local $\mathrm{VD}_{2}$ folding (Kilpeläinen, 1998, pp. 41-42; lo-
Fig. 4. Aeromagnetic low-altitude map of the Tampere Vammala area. Geological Survey of Finland, Espoo. Compiled by Maija Kurimo (after Kilpeläinen, 1998, Fig. 3, p. 17). Same area as Fig. 5.

calityV-4 in Fig. 3). Thus in both the TSB and VMB, episodes of deformation and metamorphism synchronous with granitoid intrusion at $\sim 1.88 \mathrm{Ga}$ have been identified. In the VMB there is an earlier episode, $\mathrm{VD}_{1}$, thought to coincide with peak metamorphism, but no such epi- 


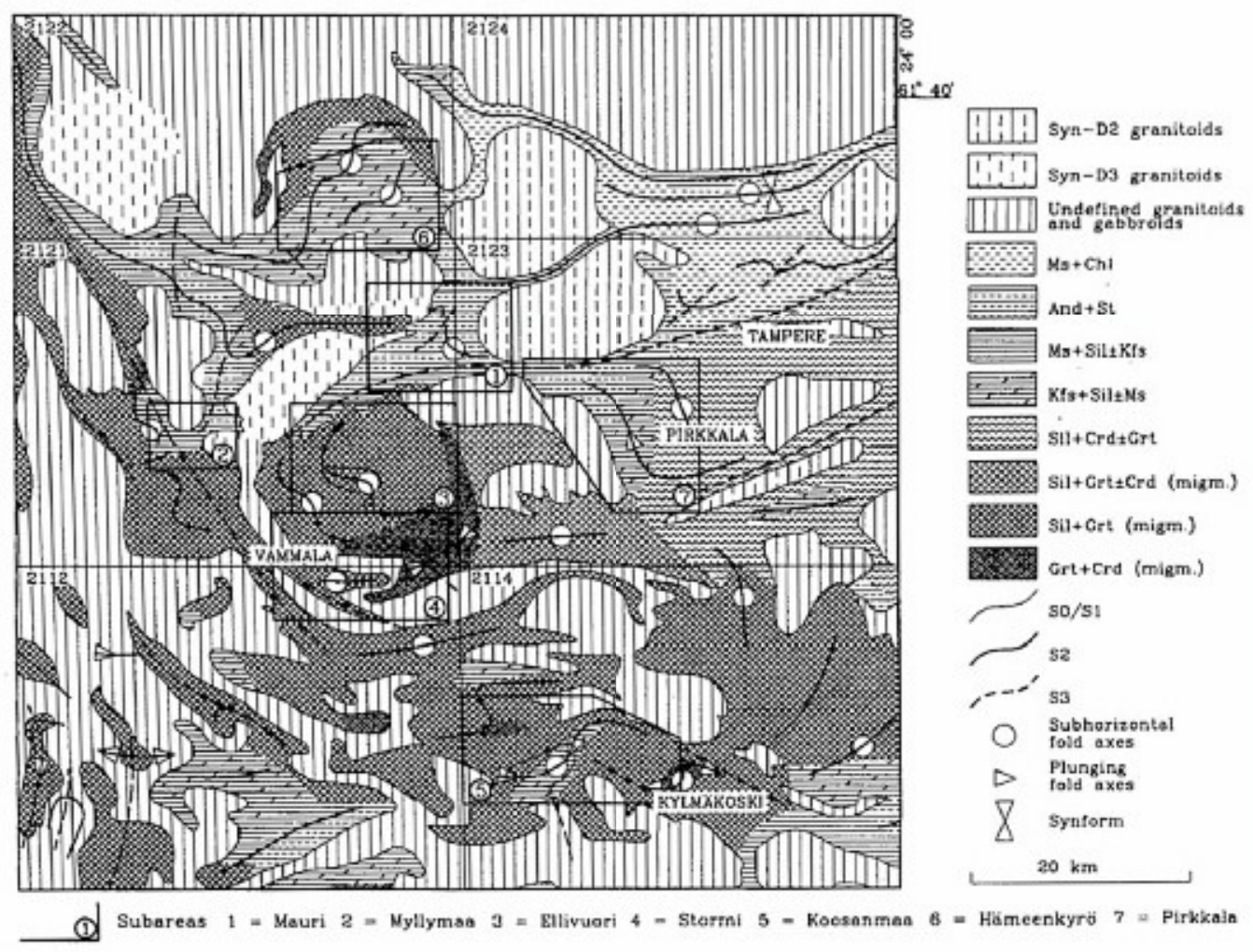

Fig. 5. Metamorphic map of the Tampere-Vammala area (from Kilpeläinen, 1998, Fig. 5I, p. 79). Map sheets: $2122=$ Ikaalinen, 2 I 24 = Viljakkala-Teisko, 2 I2I = Vammala, 2 II 2 = Huittinen, 2 II 4 = Toijala.

sode has been identified in the TSB. Kilpeläinen et al. (1994, p. 30) also recognised that the early, originally recumbent $\left(\mathrm{VD}_{1}\right)$ deformation and associated garnet-cordierite-sillimanite-biotite metamorphism are characteristic of the VMB, while the TSB was metamorphosed only during the later upright $\left(\mathrm{TD}_{1}\right)$ deformation and is characterised by andalusite, staurolite and garnet assemblages (Fig. 5). As a result, in the VMB, $\mathrm{VS}_{2}$ and $\mathrm{VS}_{3}$ are usually crenulation cleavages, superposed on $\mathrm{VS}_{1}$, while in the TSB, TS 1 forms a penetrative schistosity, with no evidence of an earlier schistosity.

There is no doubt from the field evidence that $\mathrm{VD}_{1}$ is earlier than the intrusive granitoids, but it has previously been considered to be close in age to the main TSB folding, and to post-date deposition of all or part of the TSB succession. Kil- peläinen et al. (1994, p. 30) explain this only by suggesting that "the temperature and age of metamorphism and the beginning of structural evolution" increase as a function of depth. This and other tectonic interpretations depend heavily on the assumption that the stratigraphic correlation between the turbidites of the TSB and the metasediments in the north of the VMB is valid (e.g. Kilpeläinen et al. 1994, pp. 30-32; Kilpeläinen, 1998, pp. 77, 99, 101 and 113). On this assumption, $\mathrm{VD}_{1}$ must be younger than at least part of the TSB and thereby was assumed to have a maximum age of $\sim 1.91 \mathrm{Ga}$, the age indicated by the youngest detrital zircon in the TSB turbidites, and a minimum age of $-1885 \mathrm{Ma}$, the age of intrusions associated with the main TSB folding.

An alternative reading of the evidence would argue that granitoid pebbles dated at $-1.89 \mathrm{Ga}$ 
were incorporated in the TSB succession before $1889 \pm 5$ Ma. Given the field evidence that VD pre-dates such granitoids, $\mathrm{VD}_{1}$ must have occurred before the deposition of the upper part of the TSB succession; and given the fact that the lower part of the TSB succession shows only the same post-TSB structures as the upper part, it is also plausible that $\mathrm{VD}_{1}$ pre-dates the whole of the TSB succession. If this is correct, the previously assumed stratigraphic correlation of the sedimentation in the VMB with that in the TSB is not possible and no longer places an older limit on $\mathrm{VD}_{1}$.

In general, early structures, which might correlate with $\mathrm{VD}_{1}$, are absent from the TSB, consistent with $\mathrm{VD}_{1}$ being older, and with the basement-cover hypothesis. However, some outcrops containing such structures have previously been allocated to the TSB (Koistinen et al., 1996; Kilpeläinen, 1998). We have therefore reexamined the critical field evidence, especially in key outcrops close to the boundary between the TSB and VMB. In no case does it appear that their allocation to the TSB is valid.

\subsection{Critical field evidence}

The main gneiss area in the SE of the Ikaalinen map sheet (Virransalo \& Vaarma, 1993; the Hämeenkyrö sub-area of Kilpeläinen, 1998; see Figs. $4 \& 5$ ) has sometimes been interpreted as part of the TSB, although its broad similarity to the Vammala migmatites has usually been recognised (for example, Kähkönen, 1999; Huhma et al., 1952). It appears to form a dome-like structure, with synclinal prolongations from the main TSB outcrop both to the NE and SE. The aeromagnetic pattern and the fold pattern show similar complexity to that of the main part of the VMB (Kilpeläinen, 1998, pp. 57-62, and Fig. 31 ), suggesting that this is a northerly extension of the VMB. One of our samples, Ikaalinen-1 (I1 in Fig. 3) was therefore taken from this gneiss area. $\mathrm{VF}_{2}$ folds in potassium feldspar-sillimanite gneisses have a sinuous, roughly NE, trend (Fig. 5) and refold an early layer parallel schistosi- ty that we attribute to $\mathrm{VD}_{1}$. In the north, $\mathrm{VF}_{3}$ crenulation cleavage and open folds trending WNW, are parallel to the trend of the syncline of TSB rocks to the northeast and the TSB syncline north of the Lavia Granite. This suggests a correlation between this cleavage and the principal folding $\left(\mathrm{TD}_{1}\right)$ in the overlying TSB.

In the extreme SE of the map sheet, this gneiss complex is juxtaposed with another syncline of TSB rocks, trending NE. These are muscovite chlorite grade metasediments (Fig. 5), which preserve sedimentary structures and younging directions (Ikaalinen map sheet, 1993 edition, locality I-2 in Fig. 3), in remarkable contrast to the nearby high-grade gneisses that are much coarser grained and show evidence of superposed deformations. Other gneisses in the vicinity have more variable $\mathrm{E}$ to $\mathrm{NE}$ trends and display a differentiation schistosity, and near isoclinal $\mathrm{VF}_{2}$ folds plunging steeply southwest. Open $\mathrm{VF}_{3}$ folds and crenulation of the early foliation and lineation have a NE to ENE trend and can be correlated with the trend of the adjacent TSB syncline. We interpret the abrupt change in structural and metamorphic character (compare Fig. 32b with Figs. 32c \& 32e of Kilpeläinen, 1998) as indicating a relatively undisturbed unconformable relationship.

A key area lies on the southern margin of the TSB, immediately south of the outcrop of the Mauri meta-arenite (Fig. 3). Kilpeläinen (1998, p. 99) states that $D_{1}$ structures are visible in the andalusite schists above the Mauri meta-arenite, which itself is high in the stratigraphic succession (section 2.1). These schists were inferred to overlie "the western contact of the north-south trending part of the meta-arkose". At locality V-1 (Fig. 3; GR 6819.80N, 2460.30E, Vammala 1:100 000 map sheet, Matisto, 1967), the schists show growth of andalusite after the principal fine-grained schistosity (op. cit. Fig. $7 \mathrm{~b})$, which can be correlated with TS . No earlier schistosity or fold structure has been identified in this vicinity, and there can be little doubt that at this locality the schists do stratigraphically overlie the Mauri meta-arenite. However, 
rocks several kilometres to the SSW that have also been allocated to the TSB show quite different structural relationships.

At locality V-2 (Fig. 3), refolding of an earlier (local $\mathrm{S}_{1}$ ) schistosity has been recognised (op. cit. Figs. 4, 5a and 5b; GR 6817.70N, 2453.65E). These rocks were included in the TSB on the assumption that they also stratigraphically overlie the Mauri meta-arenite. Our detailed re-examination shows, however, that this is highly unlikely and that this locality is separated from the metaarenite by an important shear zone.

The meta-arenite shows good primary layering, which is often planar. Locally, tight upright mesoscopic folds occur with a fine-grained axialplane schistosity that has constant orientation. As at locality $\mathrm{V}-1$, this single upright schistosity correlates with the main folding of the TSB (i.e. it is $\mathrm{TS}_{1}$ ). The well-preserved planar layering and the simple prograde metamorphism preclude the possibility that earlier structures were present, but obliterated by transposition.

The refold structures at locality V-2 contrast sharply with this simple structure in the adjacent Mauri meta-arenite. The rocks display relatively coarse $S_{1}$ and $S_{2}$ schistosities that were developed during high-grade metamorphism prior to refolding by $\mathrm{F}_{3}$ (Kilpeläinen, 1998, Figs. $5 \mathrm{a}$ and $5 \mathrm{~b}$ in strong contrast to Fig. $7 \mathrm{~b}$ above). Locally, these coarse-grained rocks contain sillimanite (op. cit. p. 20). Granitic veins cut the early schistosity but behaved as competent layers during the refolding. $\mathrm{F}_{3}$ is accompanied by an axial-plane crenulation cleavage that is parallel to the single prograde schistosity in the Mauri meta-arenite. This youngest cleavage is very strong close to the meta-arenite.

We therefore now correlate the single schistosity $\left(\mathrm{TS}_{1}\right)$ in the meta-arenite with the $\mathrm{F}_{3}$ crenulation cleavage in the V-2 outcrops and regard the latter as part of the Vammala migmatites. We now consider the $S_{1}$ and $S_{2}$ schistosities in the V-2 outcrops to be $\mathrm{VD}_{1}$ and $\mathrm{VD}_{2}$ structures that have been re-folded and retrograded, producing abundant muscovite, during the $\mathrm{VD}_{3}$ deformation that produced the $\mathrm{TF}_{1}$ fold- ing of the Mauri meta-arenite. The sharp contact with the meta-arenite is here interpreted as a $\mathrm{TS}_{1}$ shear parallel to the $\mathrm{TS}_{1}$ schistosity in the latter, and to the correlated $\mathrm{VS}_{3}$ crenulation cleavage in the Vammala migmatites. The aeromagnetic map (SW corner of sub-area 1, Fig. 4) defines the location of the W trending shear, which separates the contrasting aeromagnetic signatures of the Vammala migmates to the south and the Mauri meta-arenite to the north. The corresponding contrast between muscovite/ sillimanite/potassium feldspar and andalusite/ staurolite metamorphism is shown in Fig. 5 (after Kilpeläinen, 1998, Fig. 51).

The Mauri arenites are considered to be high in the stratigraphic succession. Their presence on the southern margin of the TSB, and in direct, albeit sheared, contact with the migmatites of the VMB, strongly suggests erosion and overstep of the lower succession as a result of the syn-depositional tectonic activity. Thus, prior to the folding and shearing of the TSB succession, it is likely that the Mauri arenites rested unconformably on the already deformed VMB.

There is another key area west of Pirkkala on the Tampere map sheet. West of locality Ta1 (Fig. 3), greywackes with good sedimentary structures and N-S strike exhibit a simple aeromagnetic signature showing distinct $\mathrm{N}$-trending bands (Fig. 4), in strong contrast to the Vammala migmatites to the east, which show refolding on a NW trend. Again the structural change is accompanied by an abrupt change in metamorphic assemblages from andalusite + staurolite to sillimanite + potassium feldspar + muscovite (sub-area 7 in Fig. 5). Locality Ta-1 (Fig. 36a of Kilpeläinen, 1998) is here interpreted as a shear zone between fine-grained TSB rocks to the west (op. cit. Fig. 36c) and coarse-grained retrograded VMB gneisses to the east (op. cit. Fig. 38).

These examples from critical localities consistently demonstrate the very abrupt change from coarse-grained gneisses, showing complex folding and an early $\mathrm{VD}_{1}$ metamorphism, to much finer grained schists showing only sim- 
ple post-TSB structures and a late lower grade metamorphism associated with the $\mathrm{TD}_{1}$ schistosity. The latter consistently correlates with a late fold and crenulation cleavage phase, $\mathrm{VD}_{3}$, associated with retrogression in the gneisses. Thus, the peak metamorphisms on either side of the boundaries at these localities are geologically of different age, as has long been recognised (Kilpeläinen et al., 1994, p. 30, see above). Only the layering in the TSB rocks is parallel to the boundaries. The boundaries are therefore discordant with respect to lithology, metamorphism, and structural style and history. The contacts must be abrupt and the relationships are quite characteristic of a basement-cover relationship in which the basement shows deformation and metamorphism not represented in the cover. The presence of the antiformal inlier of VMB in the SE Ikaalinen area, with synclinal prolongations of the TSB to north and south, (and reflected in the aeromagnetic contrast in Fig. 4) also strongly supports the basement-cover hypothesis. The post-TSB metamorphism has a maximum age of $1889 \pm 5 \mathrm{Ma}$, the age of the youngest dated volcanic member, and probably peaked at $\sim 1880 \mathrm{Ma}$. We have therefore tried to date the $\mathrm{VD}_{1}$ metamorphism directly, to provide a definitive test of the hypothesis.

\section{Sample selection}

Korsman and Korja (1994) remarked, "Unfortunately, we have very little information on the evolution of the orogeny in the time interval 1980-1885 Ma because the major thermal pulse at $1885 \mathrm{Ma}$ obliterated and melted the rocks recording the pre-collision orogenic stages." Therefore, for the present study an attempt was made to select samples containing $\mathrm{VS}_{1}$ where the visible effect of younger events was minimal, and where the $S_{2}$ component in the schistosity was likely to be minimised.

\section{I.The Toijala area}

Metasedimentary sample Toijala-1 (ANU ac- cession no. 99 0573; ) was taken from the interior of the migmatite belt, in the NE of the Toijala 1:100 000 geological map area (sheet 2114, Matisto, 1973). Horizons interpreted as black schists are prominent in the aeromagnetic image of the area and appear to delineate an early macroscopic fold structure (local $\mathrm{F}_{1}$ ), refolded (by the local $\mathrm{F}_{2}$ ) on a NE trend (Fig. 4). The geometry suggests an original NNW trend for $\mathrm{F}_{1}$. At the sample locality (Fig. 3; GR 6796.35N, 2492.65E; $7.3 \mathrm{~km}$ from Lempäälä towards Kärjenniemi on road 3041), in the NW limb of this major structure, the principal schistosity $\left(S_{1}\right)$ is sensibly parallel to primary lithological banding (Fig. 6a), and is allocated to $\mathrm{VD}_{1}$. The sample is a plagioclase-quartz-biotite gneiss dominated by fine-grained quartz and plagioclase $(\sim 0.1-0.2$ $\mathrm{mm})$, with biotite and minor garnet. There are also larger $(-1 \mathrm{~mm})$ plagioclase grains with numerous quartz inclusions, as well as large quartz grains and aggregates, and elongate biotite aggregates, both up to $2 \mathrm{~mm}$ long.

The metamorphism in this part of the VMB is characterised by sillimanite + garnet (Kilpeläinen et al., 1994). Porphyroblast-schistosity relations suggest that peak metamorphism occurred during $\mathrm{VD}_{1}$ (Kilpeläinen, 1998, Fig. 61), although metamorphic crystallisation and migmatisation continued in some areas throughout the structural evolution (e.g. Kilpeläinen, 1998, pp. 55-56). At the sample locality, thin bands of concordant leucosome are parallel to $S_{1}$ and probably formed during $\mathrm{VD}_{1}$. Younger leucosome occurs in crosscutting veins, which locally form a conjugate pair, suggesting that the younger generation was emplaced under more brittle conditions. Neither leucosome generation was visible in the collected sample.

Granitoid sample Toijala-2 (ANU accession no. 990575 ) was collected about $1.1 \mathrm{~km} \mathrm{NW}$ of Toijala-1, from a major road cut west of Mäyhäjärvi, about $6.1 \mathrm{~km}$ from Lempäälä towards Kärjenniemi (GR 6797.15N, 2491.80E). The rock is quartz-dioritic gneiss without microcline, but is cut by undeformed leucocratic microcline bearing veins. Large rafts of the coun- 

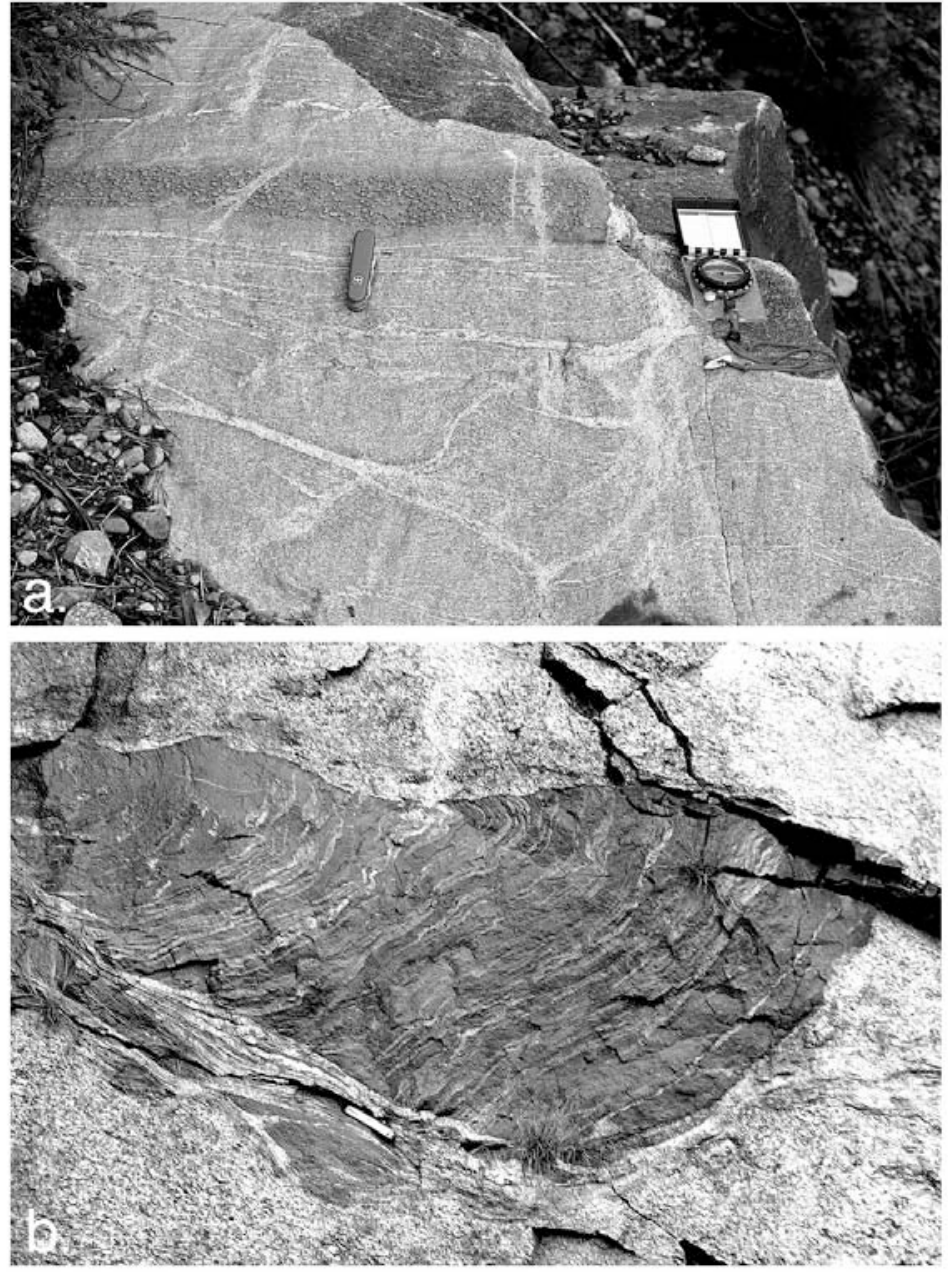

Fig. 6. Field photographs to illustrate structural relationships.

a. Greywacke at Toijala-I sample locality. Note that early leucosome and schistosity are parallel to primary garnetiferous layer (above penknife).

b. Enclave of metasediment in granitoid at Toijala-2 sample locality, showing that emplacement post-dated the early schistosity and leucosome. try rock occur in the granitoid and it is clear that the main schistosity and concordant leucosome in the rafts pre-date the emplacement of the granitoid (Fig. 6b). The macroscopic field relations also suggest that granitoid emplacement post-dated the macroscopic refolding (local $\mathrm{F}_{2}$ ) in the country rock, referred to above. Thus the age of granitoid emplacement provides a minimum age for $\mathrm{VF}_{1}$ and probably for the local $\mathrm{VF}_{2}$ also.

\subsection{The SE Ikaalinen area}

Metasedimentary sample Ikaalinen-1 (ANU accession no. 99 0574) comes from the Ikaalin- en 1:100 000 geological map area (sheet 2122, Virransalo \& Vaarma, 1993), about $8 \mathrm{~km} \mathrm{~W} \mathrm{of}$ Hämeenkyrö (Fig. 3). The locality was previously studied by Kilpeläinen (1998, pp. 58-59 and Fig.32a, GR 6837.00N, 2449.50E).

The general structure has been outlined in section 2.3 above. The area is characterised by the potassium feldspar + sillimanite \pm muscovite metamorphic assemblage (Fig. 5 after Kilpeläinen, 1998, Fig. 51). The sillimanite occurs as fibrolite aggregates, elongated in $S_{1}$, and commonly shows retrogression to muscovite (op. cit. p. 61). We infer that peak metamorphism occurred during $\mathrm{D}_{1}$ and that the retrogression probably occurred during the post- 
TSB events, when the rocks of this area were at no great depth below the overlying TSB. Ikaalinen- 1 is a coarse-grained arkosic metasediment, resembling a deformed granitoid. The larger grains are dominated by quartz, but plagioclase, microcline and fine-grained rock fragments rich in apatite also occur. A strong schistosity $\left(S_{1}\right)$ is approximately parallel to the primary layering, dipping gently SSW, and a linear structure trends NNW. $\mathrm{F}_{2}$ folding is not seen at this locality, but is prominent elsewhere (op. cit. pp. 58-59).

\section{Analytical techniques}

About $500 \mathrm{~g}$ of each rock sample were crushed to $<250 \mu \mathrm{m}$ and the high-density minerals $>20$ $\mu \mathrm{m}$ diameter extracted using density and magnetic separation procedures designed to prevent inter-sample cross contamination and sampling bias. Final purification was by hand picking. Zircon and monazite were mounted separately in epoxy resin with grains of reference material; zircon AS3 (radiogenic ${ }^{206} \mathrm{~Pb} / 238 \mathrm{U}=0.1859$ ) and SL13 (238 ppm U), and monazite Thompson Mine WB.T.329 (radiogenic ${ }^{206} \mathrm{~Pb} /{ }^{238} \mathrm{U}=$ 0.3152, $2100 \mathrm{ppm} \mathrm{U).} \mathrm{Mounts} \mathrm{were} \mathrm{polished}$ to expose the crystal interiors, photographed in transmitted and reflected light, then washed and Au coated before analysis. Prior to analysis, the zircons also were imaged by SEM cathodoluminescence (CL) to document their internal zoning. These images were obtained using an Hitachi S-2250N SEM fitted with an internal parabolic mirror to boost signal strength. Monazite growth structures were imaged by backscattered electron (BSE) after analysis, using a Cambridge Instruments Stereoscan 360 fitted with a 4-quadrant solid state BSE detector, and operated at $20 \mathrm{kV}$ with a $10 \mathrm{nA}$ probe current. Images from both SEMs were recorded digitally, and the brightness and contrast subsequently optimised off-line using Adobe Photoshop ${ }^{\mathrm{TM}}$.

$\mathrm{U}-\mathrm{Th}-\mathrm{Pb}$ was analysed on the RSES SHRIMP II ion microprobe using procedures similar to those described by Williams et al.
(1996). A primary ion beam of $-3 \mathrm{nA}, 10 \mathrm{kV}$ $\mathrm{O} 2^{-}$was focused to a probe $-20 \mu \mathrm{m}$ diameter and the sputtered secondary ions extracted at $10 \mathrm{kV}$, mass analysed at a resolution of -5000 , and the $\mathrm{Ce}, \mathrm{Zr}, \mathrm{Pb}, \mathrm{U}$ and $\mathrm{Th}$ species of interest measured on a single electron multiplier by cyclic stepping of the analyser magnet field. Weak energy filtering was used for the monazite analyses to reduce a molecular isobaric interference at mass 204. Isotopic compositions were measured directly, without correction for mass fractionation. Common $\mathrm{Pb}$ levels were comparable to those measured on $\mathrm{Pb}$-free targets, so were corrected, using ${ }^{204} \mathrm{~Pb}$, assuming laboratory contamination by $\mathrm{Pb}$ of Broken Hill galena composition. Corrections for $\mathrm{Pb}-\mathrm{U}$ fractionation utilised a power law (Claoué-Long et al., 1995). The correction factor for Th- $U$ fractionation in monazite $(0.863)$ was calculated directly from a ${ }^{208} \mathrm{~Pb} /{ }^{206} \mathrm{~Pb}-\mathrm{Th} / \mathrm{U}$ isochron as outlined by Williams et al. (1996). Analytical uncertainties listed in the tables and plotted in the figures are one standard error precision estimates based on the uncertainties in the time-interpolated count rates from which the ion ratios were calculated. Ages were calculated using the constants recommended by the IUGS Subcommission on Geochronology (Steiger \& Jäger, 1977). Uncertainties in the ages cited in the text are 95\% confidence limits, namely to, where $t$ is 'Student's t'.

\section{Zircon isotopic compositions}

\section{I. Quartz diorite Toijala-2}

The zircon from this gneissic granitoid consists of mostly euhedral, finely zoned prismatic grains 50 to $150 \mu \mathrm{m}$ diameter with aspect ratios of 2 : 1 to $5: 1$, features typical of zircon from a felsic plutonic rock. The CL of the zircon grains is very weak, but shows that, although most grains are euhedrally zoned throughout, some contain a structurally discordant core, and some have a thin, discordant, more luminescent rim.

Fourteen areas were analysed for U-Th- Pb, including two on cores and one on a CL-bright rim (Table 1). The zircon has a very wide range 


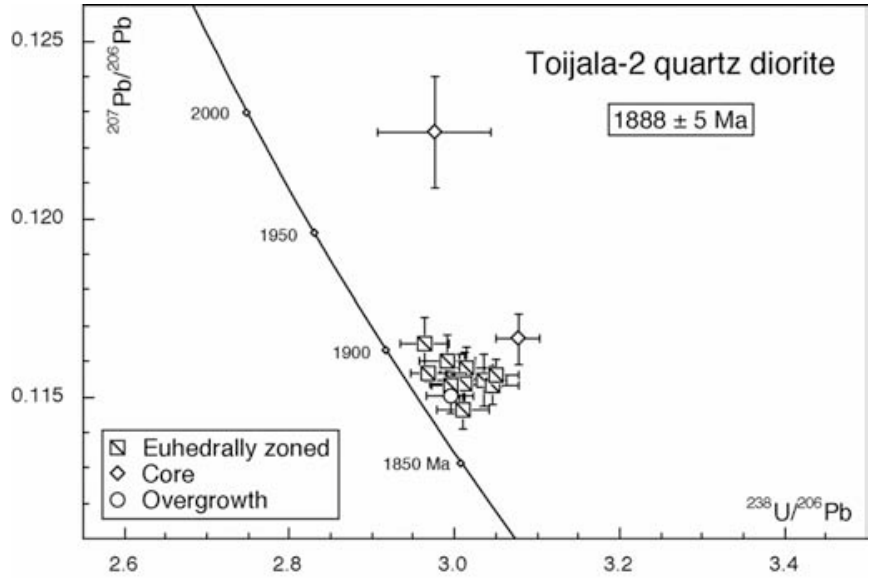

Fig. 7.Tera-Wasserburg concordia diagram for zircon from the Toijala-2 quartz-diorite. of $U$ contents (70-2070 ppm), the lowest value being from one very strongly luminescent core (12.1). With the exception of that core, $\mathrm{Th} / \mathrm{U}$ is very uniform (mostly $0.2-0.3$ ), consistent with all the grains sharing a common igneous origin. Again with the exception of that core, all the analyses plot in a uniformly discordant cluster at $\sim 1.9 \mathrm{Ga}$ (Fig. 7). The analyses of the rim and the other core plot within this group. There is a significant dispersion in radiogenic ${ }^{206} \mathrm{~Pb} /{ }^{238} \mathrm{U}$, so the weighted mean of the ${ }^{207} \mathrm{~Pb} /{ }^{206} \mathrm{~Pb}$ measurements, $0.11555 \pm 0.00014(\sigma)$, all of which are equal within analytical uncertainty, gives the best estimate of the zircon age, $1888 \pm 5$ (to) Ma. This is interpreted as the age of crystallisation of the quartz diorite magma. It is comparable to the age of granitoid clasts that appear in conglomerates below the upper part of the succession in the TSB, by which time such granitoids were exposed to erosion. The luminescent core is significantly older, $1992 \pm 23$ ( $\sigma$ ) Ma, and is interpreted as being inherited from the quartz diorite's source or host rock. Lahtinen (1996, pp. 92-93) notes only one $\mathrm{U}-\mathrm{Pb}$ zircon age from the VMB, a granodiorite from Valkeakoski giving $1896 \pm 16 \mathrm{Ma}$, indistinguishable from the age of Toijala-2.

\subsection{Paragneiss Toijala-I}

Zircon from Toijala-1 has a wide range of siz- es and morphologies. Most grains are stubby, subhedral prisms $70-100 \mu \mathrm{m}$ diameter, but some more equant grains reach $200 \mu \mathrm{m}$. Truly euhedral grains are rare. Some cores and euhedral growth zoning are visible in transmitted light, but most grains appear relatively structureless and inclusion-free. Microfracturing is common, however, many grains being cut by a maze of fine cracks. Such grains were not analysed. The CL of the zircon is stronger on average than that from the quartz diorite and varies more in strength both within and between grains (Fig. 8). About $60 \%$ of the grains have very weak CL. These consist predominantly of finely euhedrally-zoned zircon, sometimes with discordant cores and/or overgrowths. The remaining grains have much stronger $\mathrm{CL}$, and fall into two main groups, those with fine euhedral zoning, and those in which the zoning is broader and less regular. All these commonly have discordant cores and overgrowths. There are two types of overgrowths, CL bright and CL dark. Both occur as thin structureless layers seldom $>20 \mu \mathrm{m}$ thick, mostly on the CL bright grains and in about equal abundance. Where both occur on the same grain, the dark overgrowth is usually outermost.

Fifty-two U-Th- $\mathrm{Pb}$ analyses were made of 39 grains (Table 1). Most attention was focused on the overgrowths to try to date post-sedimentation metamorphism. Some host grains to the 


\section{Toijala-1}
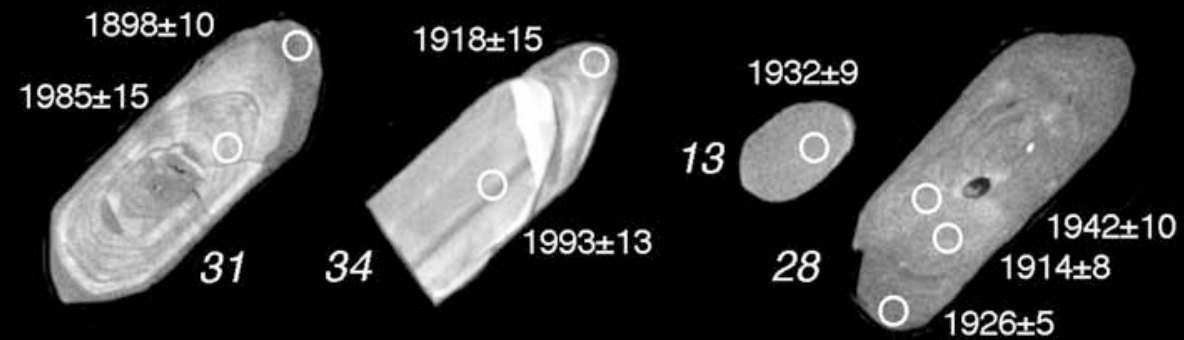

$1978 \pm 14$
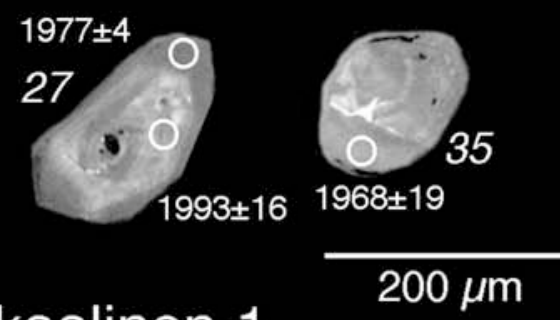

\section{Ikaalinen-1}

$2444 \pm 4$

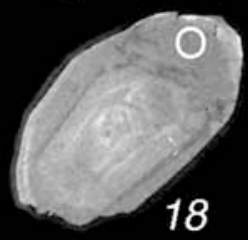

6

\section{$2698 \pm 27$}
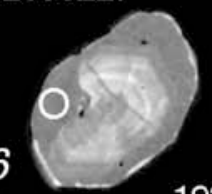

\section{$1935 \pm 23$}
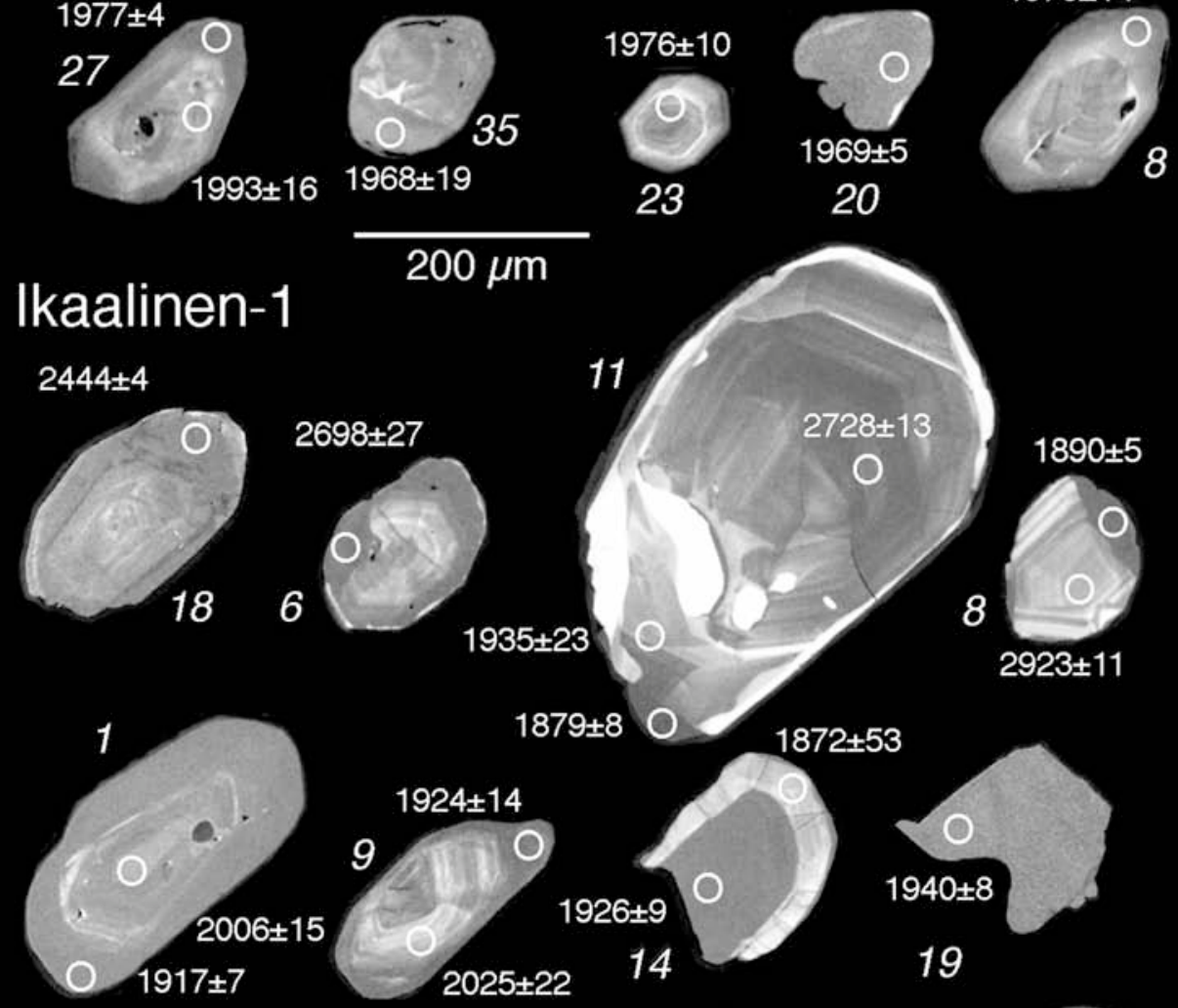

20

.
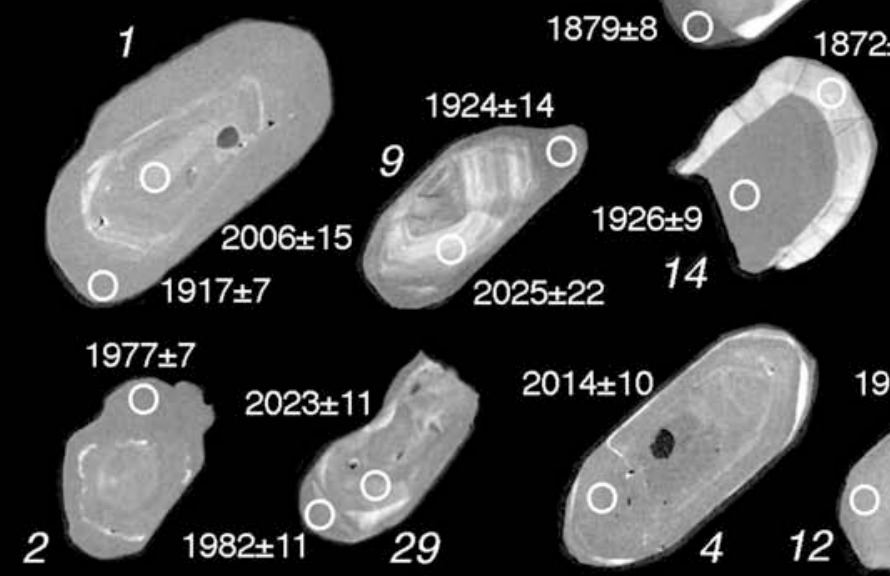

$872 \pm 53$
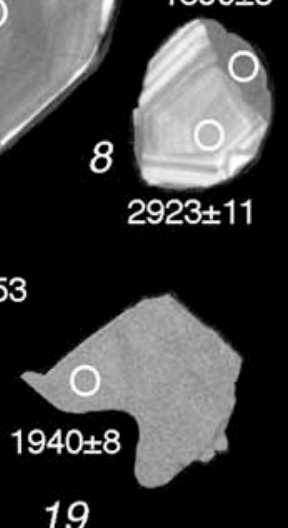

Fig. 8. Catholuminescence images of analysed zircon grains from the Vammala Metamorphic Belt.

- Rows I and 4: Low Th/U overgrowths formed during the $\sim 1.92 \mathrm{Ga}$ metamorphism from Toijala-I (grains 3I, 34, 28) and Ikaalinen-I (grains I, 9), and associated slightly older anomalous grains (grains T-I, I 3, 28 and I-I, I 4, I9; see text). Host grains (e.g. I-I, 3I, 34 and T-I, I, 9 provide examples of the main populations of zoned grains.

- Rows 2 and 5: overgrowths and associated grains representative of the $\sim 1.98 \mathrm{Ga}$ metamorphism from Toijala-I and Ikaalinen-I (grains T-I, 27, 35, 23, 20, 8 and I-I, 2, 29, 4, I2, I5; see text).

- Row 3: examples of Archaean grains with overgrowths from Ikaalinen-I. 

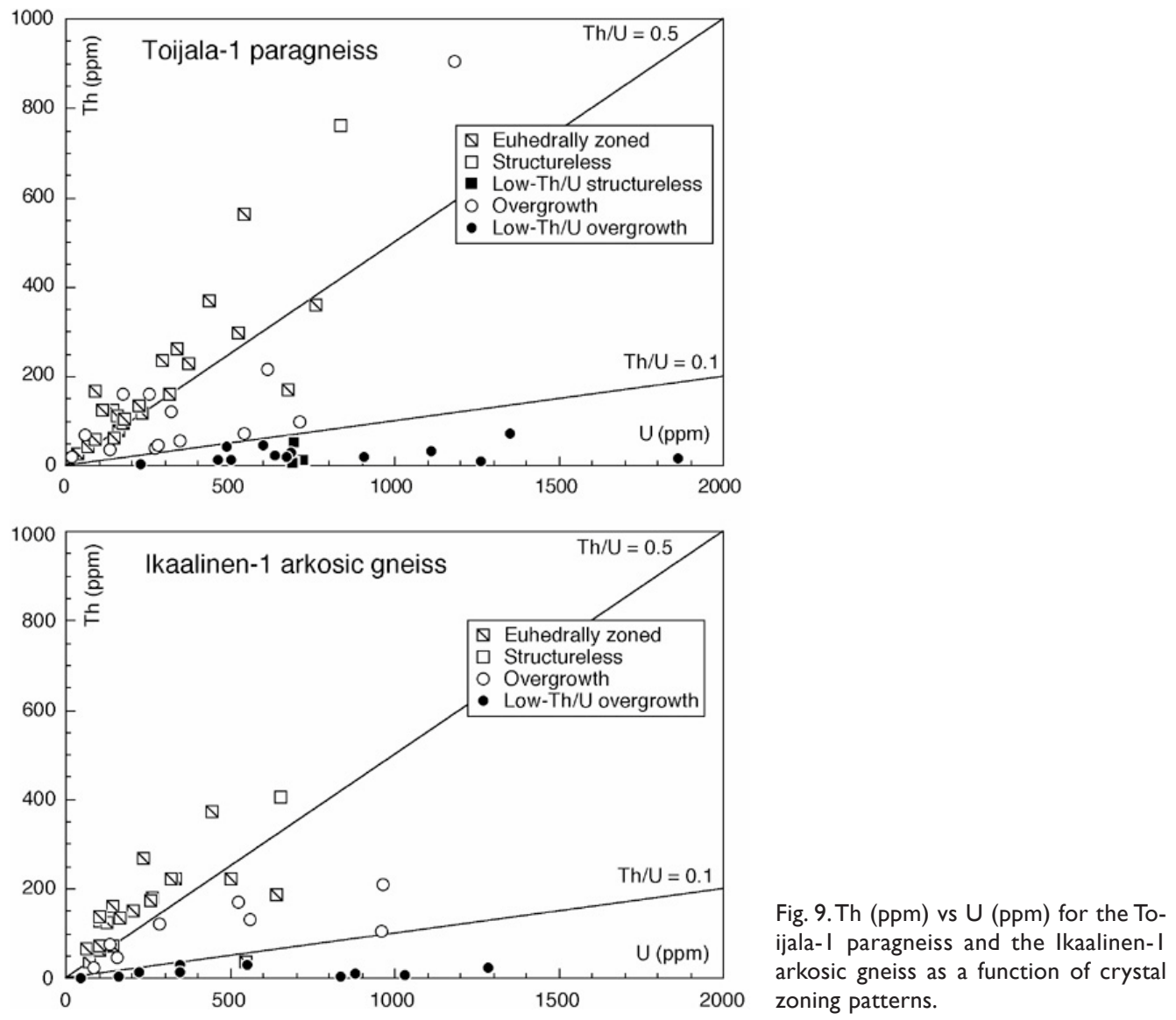

overgrowths were also analysed, as well as selected examples of the main grain types. The zircons have a very wide range of $U$ contents (17$1860 \mathrm{ppm})$ and $\mathrm{Th} / \mathrm{U}(0.007-1.8)$, consistent with zircon formed under a variety of geological conditions. The main population of euhedrally-zoned zircon (Fig. 9) has on average the lowest $\mathrm{U}(40-760 \mathrm{ppm})$ and highest $\mathrm{Th} / \mathrm{U}(>0.4)$. $\mathrm{U}$ tends to be higher ( $>200 \mathrm{ppm}$ ) in both the structureless zircon and overgrowths. A few of these grains have moderate $\mathrm{Th} / \mathrm{U}$ similar to the zoned grains, but in the majority, dominantly overgrowths, $\mathrm{Th} / \mathrm{U}$ is much lower. Many of these have $\mathrm{Th} / \mathrm{U}$ below 0.1 , a feature commonly found in zircon grown in metasediments under high-grade conditions (Williams \& Claesson, 1986; Heaman et al., 1990; Williams et al, 1996).
The isotopic compositions fall into three main groups, a small number of grains at -2.7 $\mathrm{Ga}$, and two major populations at -1.98 and 1.92 Ga (Fig. 10). Most analyses are near concordant, but in each population there is significant dispersion in $\mathrm{Pb} / \mathrm{U}$, with a limited range of radiogenic ${ }^{207} \mathrm{~Pb} / 206 \mathrm{~Pb}$.

The Archaean group is comprised of analyses of one zoned grain and three overgrowths. The latter were analysed in search of younger metamorphic overgrowths, from which they could not be distinguished by either appearance or CL response. Two are CL bright and one CL dark. None of the analysed areas is low Th/U. The four analyses also have the same radiogenic ${ }^{207} \mathrm{~Pb} /{ }^{206} \mathrm{~Pb}$ within analytical uncertainty, giving a weighted mean age of $2715 \pm 15$ (to) Ma. These grains indicate that Archaean rocks, some 


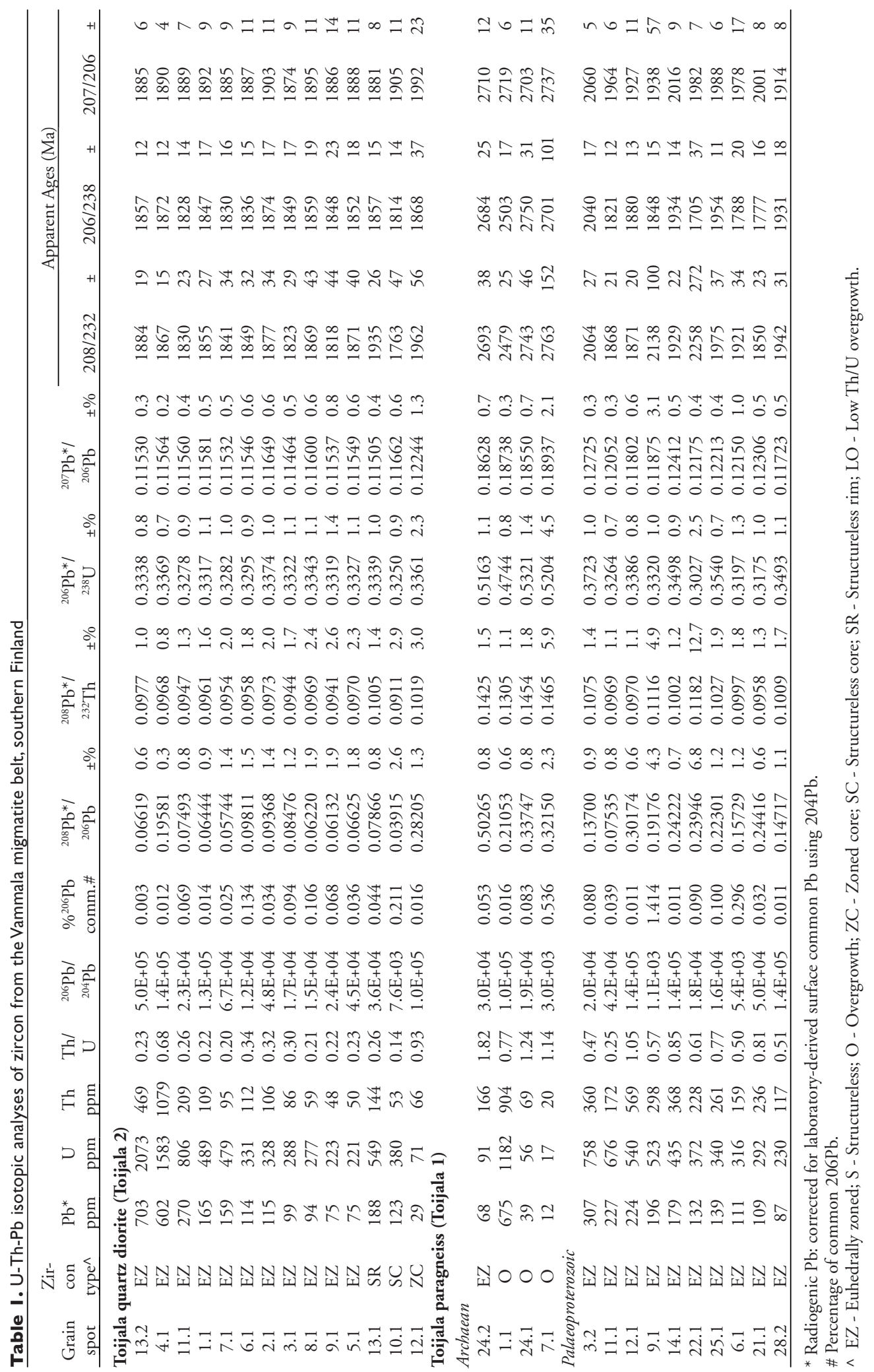




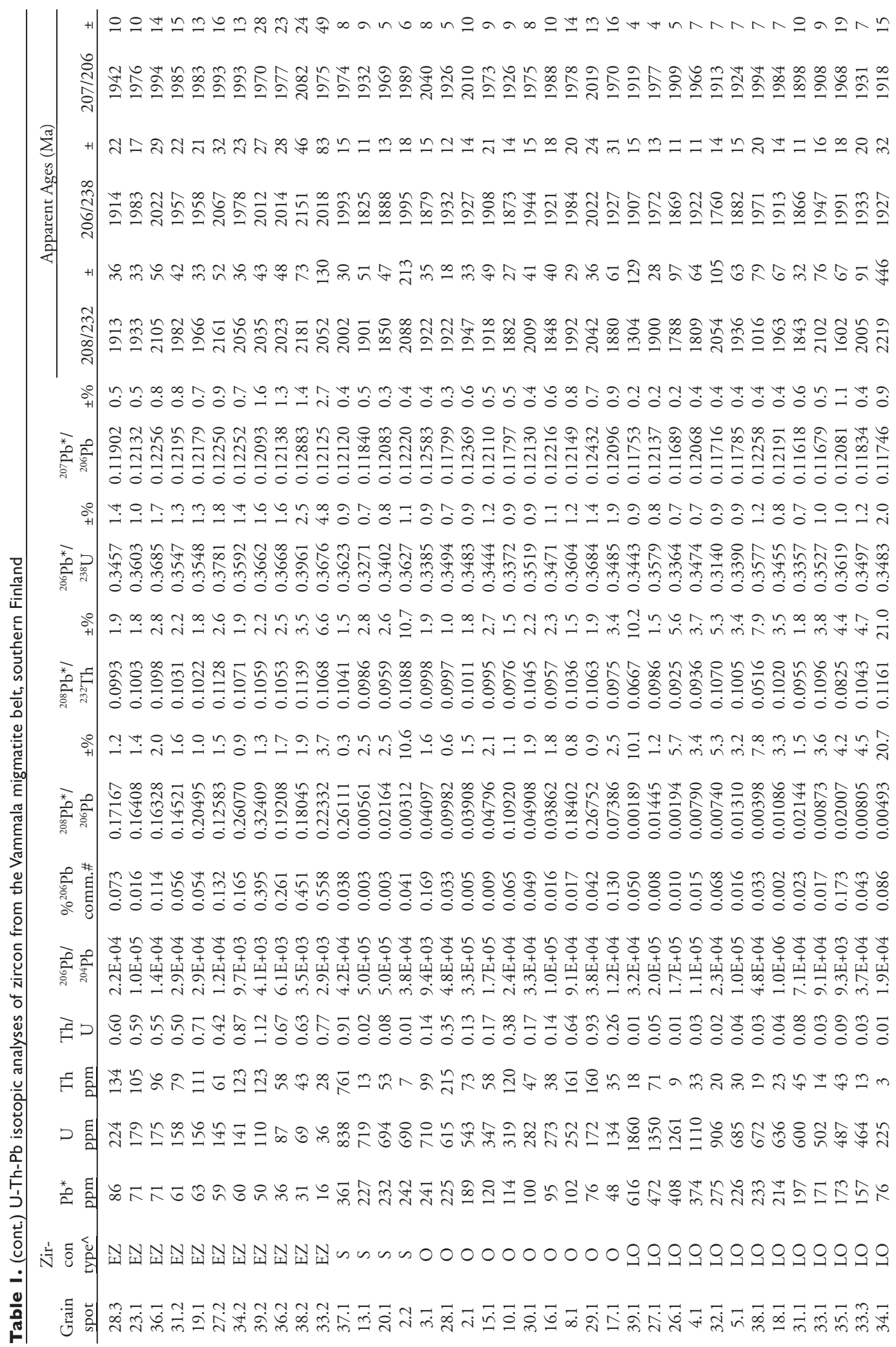


II4 Rutland, R.W.R., Williams, I. S. and Korsman, K.

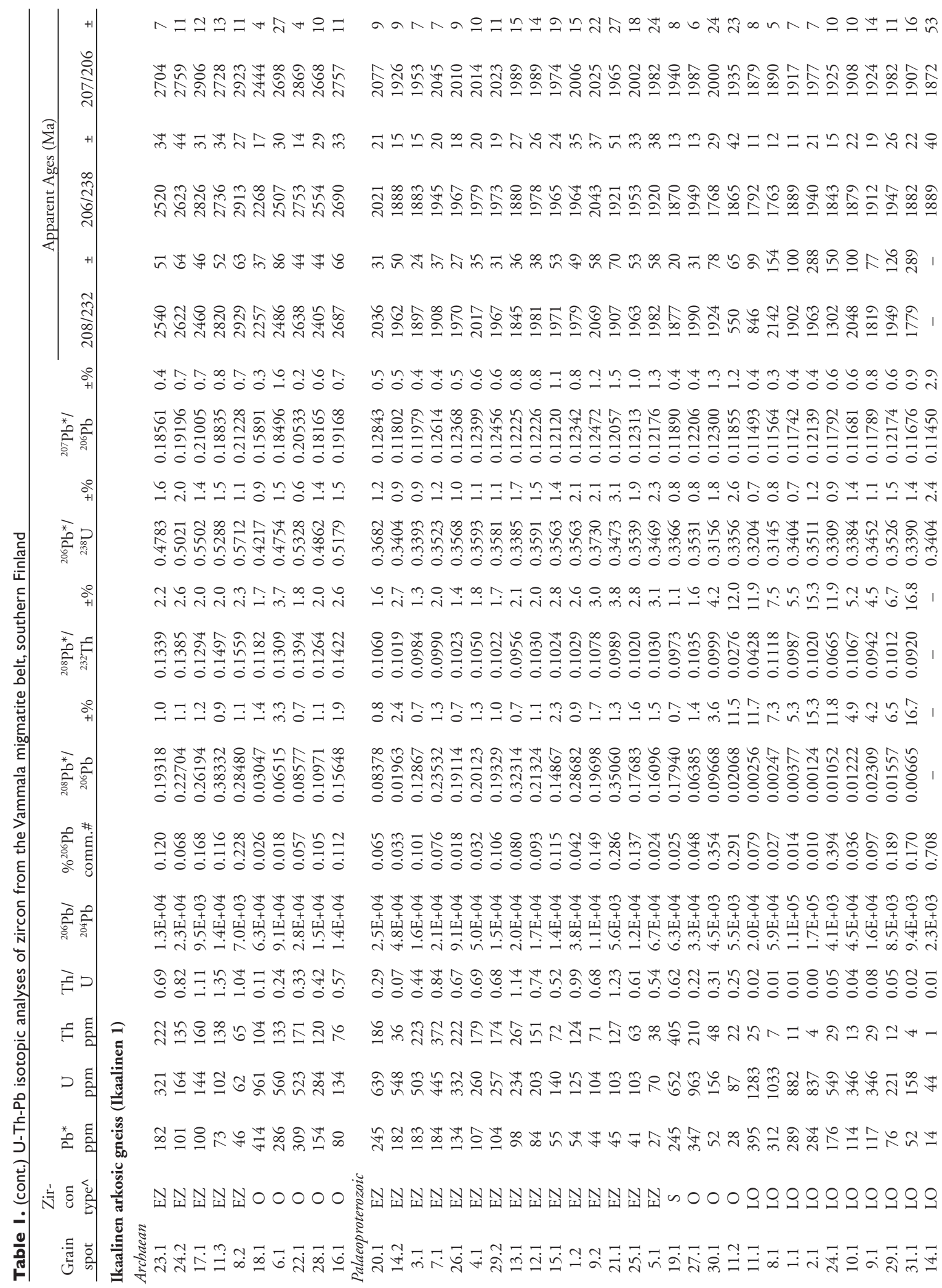




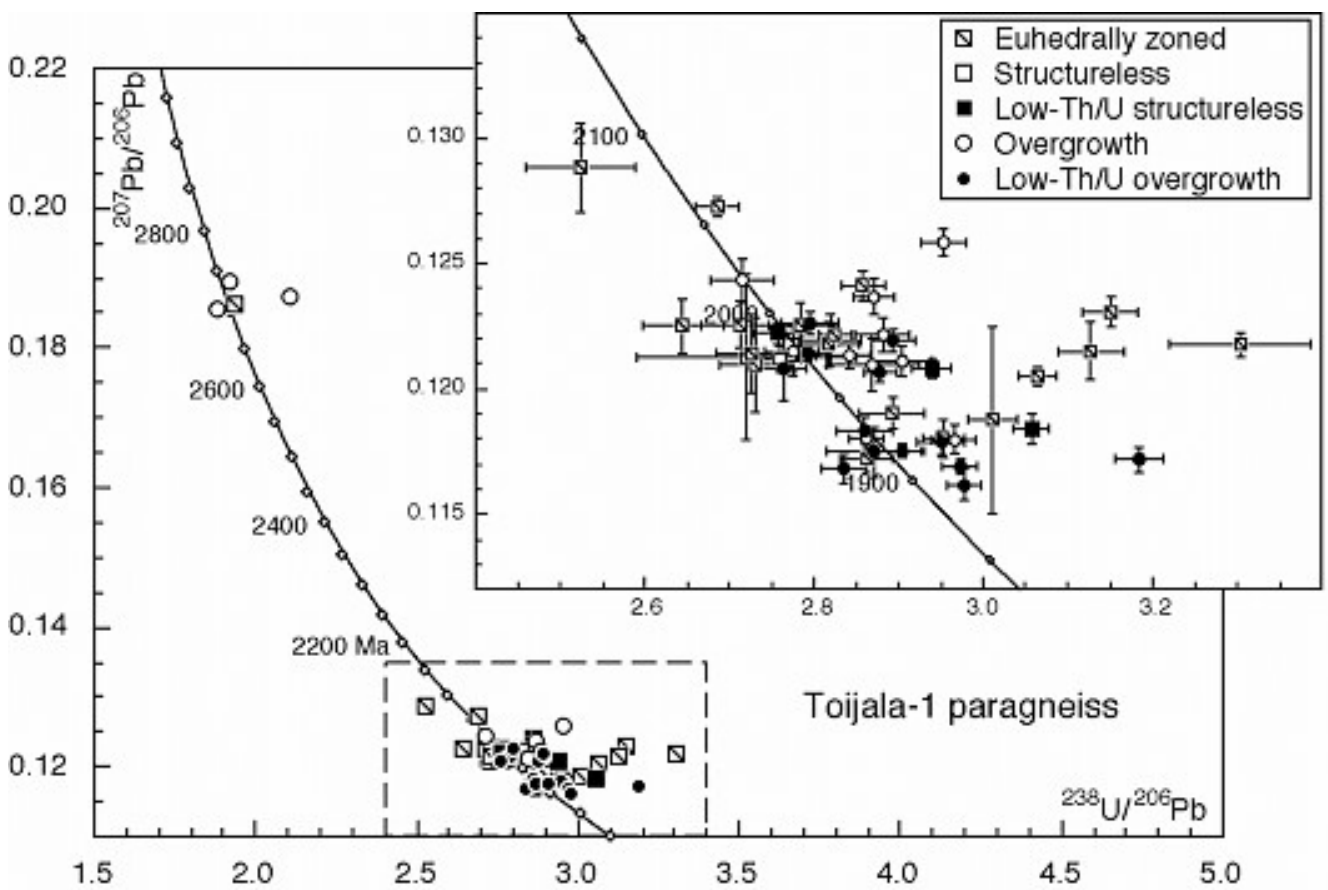

Fig. I0. Tera-Wasserburg concordia diagram for zircon from the Toijala-I paragneiss.

affected by Archaean metamorphism, were present in the sediment's source region.

The older Palaeoproterozoic group consists of most of the analyses of euhedrally zoned zircon, some of overgrowths and some of structureless zircon. The analyses are dispersed in both ${ }^{206} \mathrm{~Pb} /{ }^{238} \mathrm{U}$ and radiogenic ${ }^{207} \mathrm{~Pb} /{ }^{206} \mathrm{~Pb}$ (Fig. 10. Analyses of euhedrally zoned grains are the most dispersed, ranging in ${ }^{207} \mathrm{~Pb} /{ }^{206} \mathrm{~Pb}$ apparent age from $-2.08 \mathrm{Ga}$ to $-1.96 \mathrm{Ga}$, and from concordant to $-15 \%$ discordant. Most (14 of 17), however, have an apparent age of $-1.98 \mathrm{Ga}$. The radiogenic ${ }^{207} \mathrm{~Pb} /{ }^{206} \mathrm{~Pb}$ of all these 14 is equal analytical uncertainty, giving a weighted mean age of $1981 \pm 6$ (to) Ma. If the four most discordant analyses are omitted the age calculated does not change significant-

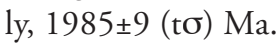

The analyses of overgrowths, one zoned grain and the structureless zircon are also dispersed in both $\mathrm{Pb} / \mathrm{U}$ and $\mathrm{Pb}$ isotopic composition. They fall into two sub-groups, three overgrowths and a zoned grain with ${ }^{207} \mathrm{~Pb} /{ }^{206} \mathrm{~Pb}$ ages of $-2.02 \mathrm{Ga}$ and the remainder at $\sim 1.98 \mathrm{Ga}$. Grains with low (metamorphic) $\mathrm{Th} / \mathrm{U}$ fall entirely within the younger sub-group (Figs. 10, 11). The ten analyses of overgrowths in the younger sub-group, including overgrowths with both low and moderate $\mathrm{Th} / \mathrm{U}$, give the same ${ }^{207} \mathrm{~Pb} /{ }^{206} \mathrm{~Pb}$ age within analytical uncertainty, $1978 \pm 5$ (to) Ma. The ages of the three structureless grains, two of which have low metamorphic $\mathrm{Th} / \mathrm{U}$, are indistinguishable from this.

When all 27 analyses in the -1.98 Ga group are combined, the radiogenic ${ }^{207} \mathrm{~Pb} /{ }^{206} \mathrm{~Pb}$ values are found to scatter very slightly more than expected from the analytical uncertainties. If the four most discordant analyses are again omitted, the scatter is eliminated, giving a weighted mean age of $1979 \pm 4(\mathrm{t \sigma}) \mathrm{Ma}$. This is the best estimate of the age of the thermal event that produced these various zircon types.

The younger Palaeoproterozoic group consists of analyses of ten overgrowths, one struc- 

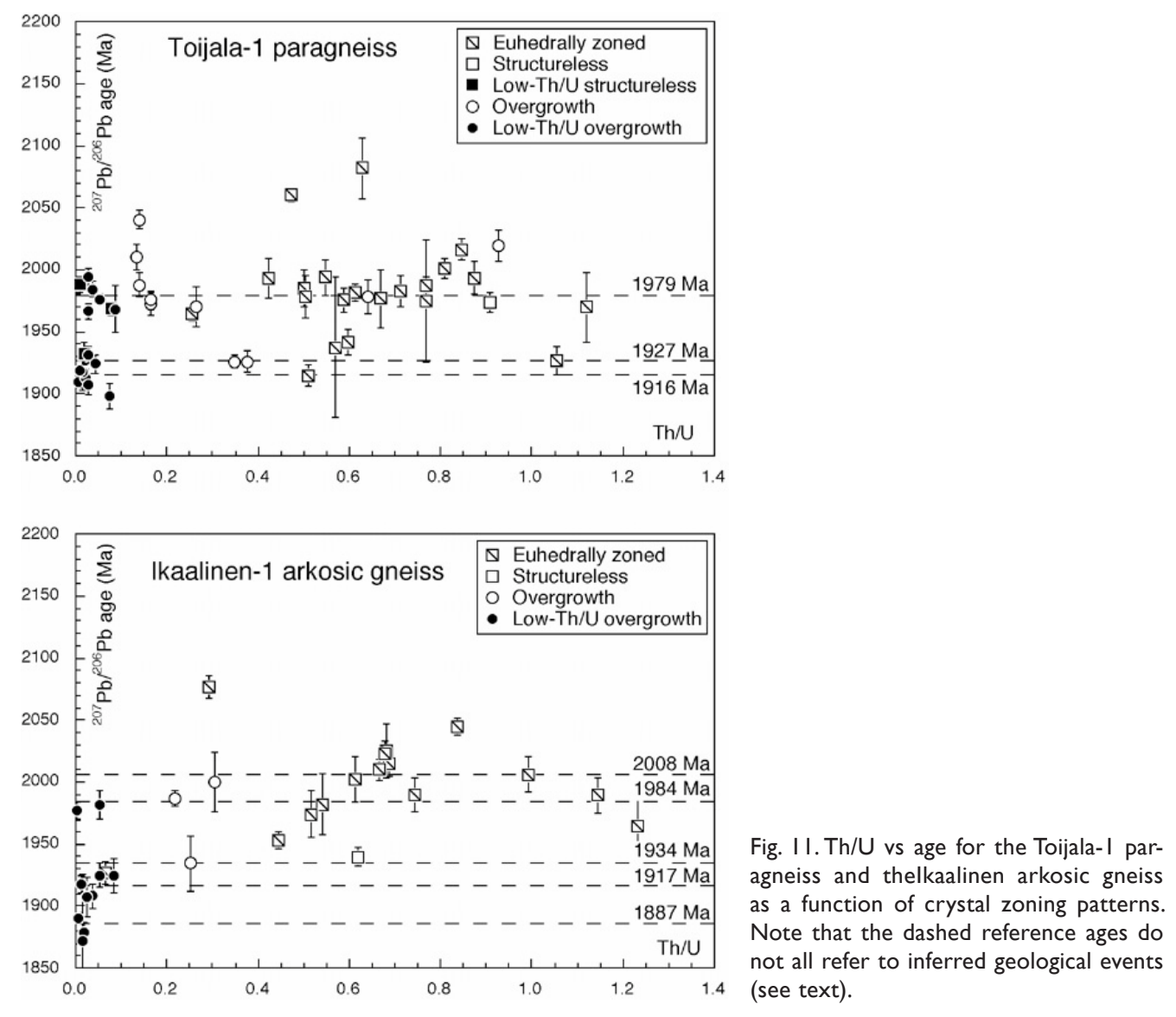

tureless and three zoned grains. The structureless grain and most of the overgrowths have low, metamorphic Th/U. Two overgrowths have intermediate $\mathrm{Th} / \mathrm{U}$ ratios, and the four analyses of three zoned grains have higher, igneous, values (Fig. 11). $\mathrm{Pb} / \mathrm{U}$ is dispersed, the analyses ranging from concordant to $10 \%$ discordant, and there is a slightly larger range in radiogenic ${ }^{207} \mathrm{~Pb} /{ }^{206} \mathrm{~Pb}$ than is expected from the analytical uncertainties. Some of the scatter is due to the radiogenic ${ }^{207} \mathrm{~Pb} /{ }^{206} \mathrm{~Pb}$ of one high $\mathrm{Th} / \mathrm{U}$ analysis being higher than the rest, but even the low Th/U analyses alone are dispersed more than expected. There is no obvious outlier, however. The two overgrowths with higher $\mathrm{Th} / \mathrm{U}$ also have high radiogenic ${ }^{207} \mathrm{~Pb} /{ }^{206} \mathrm{~Pb}$, similar to that of the structureless grain and the three zoned grains.
We have therefore separated the eight low $\mathrm{Th} / \mathrm{U}$ overgrowths (Fig. 11) from the other grain types. These overgrowths have equal ${ }^{207} \mathrm{~Pb} /$ ${ }^{206} \mathrm{~Pb}$ within error, yielding a weighted mean age of $1916 \pm 5$ (t $\sigma)$ Ma. This is considered the best estimate of the age of the youngest metamorphic zircon growth in this rock. The remaining group of six analyses of disparate grain types gives a weighted mean ${ }^{207} \mathrm{~Pb} /{ }^{206} \mathrm{~Pb}$ age of $1927 \pm 8$ (to) $\mathrm{Ma}$ (see discussion in section 7.2).

\subsection{Arkosic gneiss Ikaalinen-I}

The zircon from arkosic gneiss Ikaalinen-1 has broadly similar morphological and CL features to that from paragneiss Toijala-1, except that grains with relatively weak CL are more abun- 


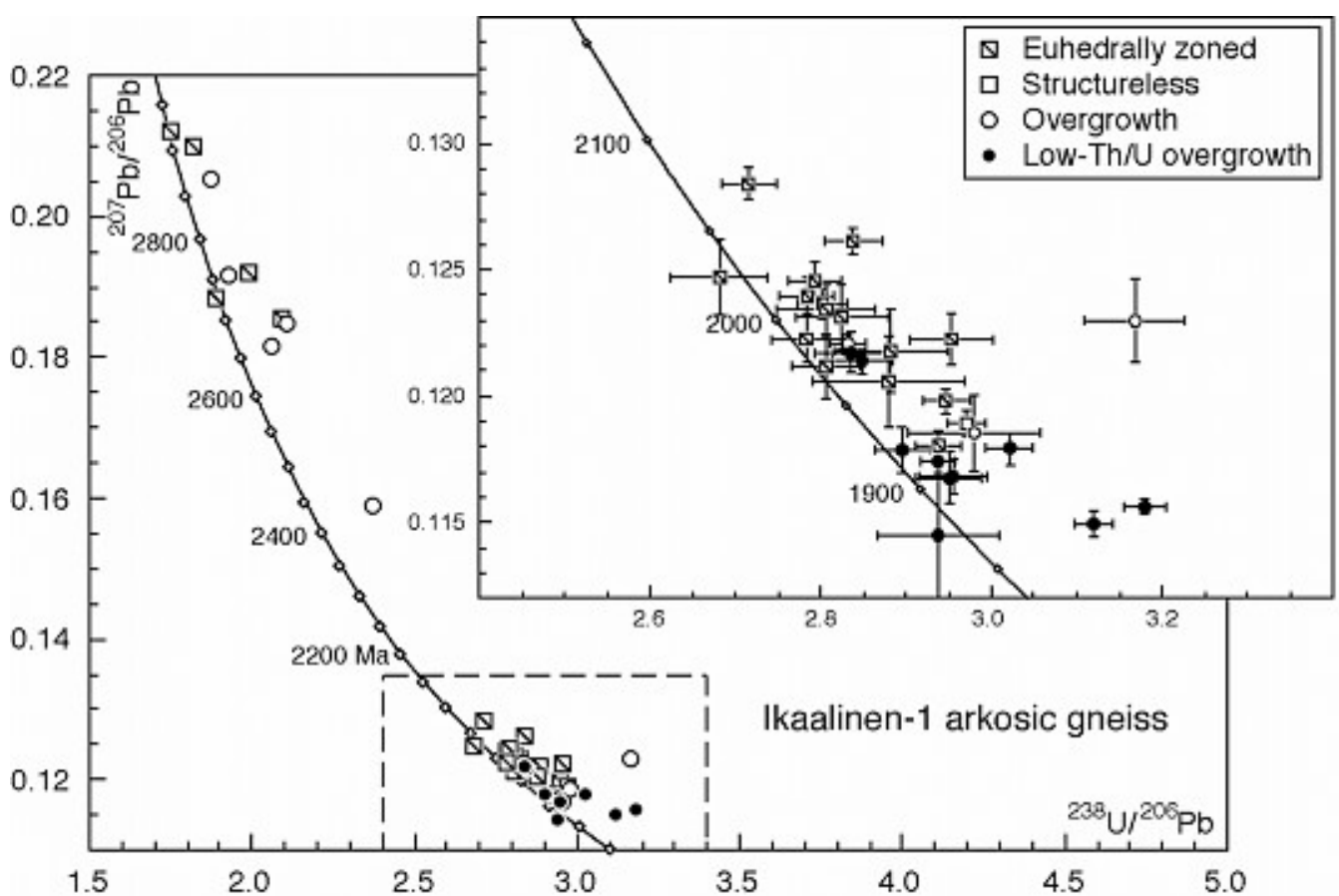

Fig. I2. Tera-Wasserburg concordia diagram for zircon from the Ikaalinen-I arkosic gneiss.

dant (Fig. 8). Analyses of 39 areas on 31 grains are listed in Table 1 and plotted in Fig. 12. As with the previous sample, structureless zircon and overgrowths, namely zircon morphologies that might record the late metamorphic history of the rock, were targeted preferentially.

The range of chemical compositions is very similar to that in the zircon from paragneiss Toijala-1; overgrowths and structureless grains have on average higher $U$ contents than the euhedrally zoned grains. The analyses yield a wide range of apparent ages, -2.92-1.87 Ga, with most clustering in the range -2.02-1.90 Ga. Most of the analyses are slightly discordant, particularly those of the older grains, which introduces added uncertainty in assessing the ages of zircon growth.

Analyses of the older grains yield ${ }^{207} \mathrm{~Pb} /{ }^{206} \mathrm{~Pb}$ apparent ages in the range -2.92-2.44 Ga. Some come from zoned zircon, but several, particularly those with lower ${ }^{207} \mathrm{~Pb} /{ }^{206} \mathrm{~Pb}$, are analyses of overgrowths (grains 18 and 6 in Fig. 8).
None of these overgrowths, however, has the very low $\mathrm{Th} / \mathrm{U}$ commonly produced by metamorphism (Fig. 9), nor is their $\mathrm{Th} / \mathrm{U}$ as high as that of the Archaean overgrowths from Toijala1. The older analyses tend to become more discordant with falling ${ }^{207} \mathrm{~Pb} /{ }^{206} \mathrm{~Pb}$, raising the possibility that all or most are defining a discordance line generated by the effects of an early $\mathrm{Pb}$-loss event on zircon of a single crystallisation age (Fig. 12). A line fitted to all analyses has an MSWD of 4. Without analysis 11.3 the MSWD falls to 2, indicating near co-linearity within analytical uncertainty. The concordia intersections, determined by a Monte Carlo line fit (Ludwig, 2001), are 2.98 $\pm 0.04 \mathrm{Ga}$ (the original zircon age) and $2.00 \pm 0.08 \mathrm{Ga}$ (the possible age of the Pb-loss event). An alternative interpretation is to consider each small cluster of ${ }^{207} \mathrm{~Pb} /{ }^{206} \mathrm{~Pb}$ ages as representing a separate zircon age, in which case the older zircons would have crystallisation ages of $-2.9,-2.75$ and $-2.69 \mathrm{Ga}$ respectively. 

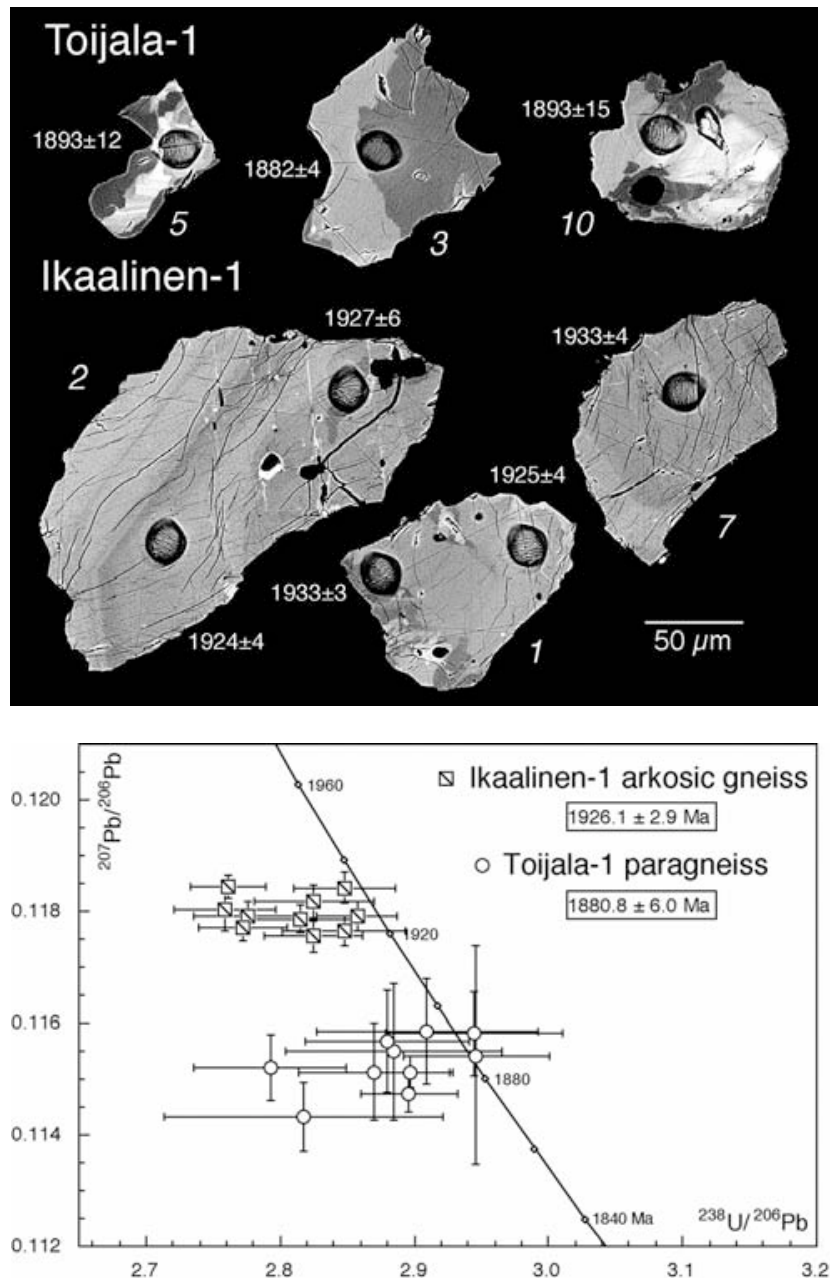

Fig. 13. Backscattered electron images showing different textures and ages of monazite from the Toijala-I paragneiss and the Ikaalinen-I arkosic gneiss (see text).

Fig. 14. Tera-Wasserburg concordia diagram for monazite from the ToijalaI paragneiss and the Ikaalinen-I arkosic gneiss.
As in Toijala-1, the Palaeoproterozoic zircon falls into two main age groups, one at $-1.98 \mathrm{Ga}$ and the other at $-1.91 \mathrm{Ga}$. Analyses of euhedrally-zoned zircon have the largest range in apparent age $(-2.08-1.93 \mathrm{Ga})$ and lie mostly in the older group (Fig. 12). The younger group is dominated by analyses of low-Th/ $\mathrm{U}$ overgrowths (Fig. 11). Analyses of structureless grains and higher-Th/U overgrowths are distributed between both. Because most analyses are discordant, radiogenic ${ }^{207} \mathrm{~Pb} /{ }^{206} \mathrm{~Pb}$ provides the best means of determining the ages.

The older Palaeoproterozoic group consists of 18 analyses, two of which have significantly higher radiogenic ${ }^{207} \mathrm{~Pb} /{ }^{206} \mathrm{~Pb}$ than the rest.
Omitting those, there is still excess scatter. Considering only the zoned grains, the data are still scattered, due to the analysis of one area with one of the highest $U$ contents of that zircon type. Omitting this analysis also, the scatter in the remaining eleven analyses is no longer significant, yielding a weighted mean ${ }^{207} \mathrm{~Pb} /{ }^{206} \mathrm{~Pb}$ age of $2005 \pm 9$ (to) Ma. The other four analyses in the group (all of overgrowths) give a mean ${ }^{207} \mathrm{~Pb} /{ }^{206} \mathrm{~Pb}$ age of $1983 \pm 14$ (to) Ma.

The younger Palaeoproterozoic group consists of 12 analyses, most of which are from overgrowths. The data are very scattered, but divide naturally into two age groups, the younger consisting of three analyses of low-Th/U over- 
growths (Fig. 8). The 9 analyses in the older sub-group, including a structureless grain, two euhedral grains, and overgrowths with both high and low $\mathrm{Th} / \mathrm{U}$, scatter more than expected from the analytical uncertainties. Dividing the sub-group in the same way as that from Toijala- 1 , the 5 oldest low-Th/U overgrowths yield a mean ${ }^{207} \mathrm{~Pb} /{ }^{206} \mathrm{~Pb}$ age of $1917 \pm 12(\mathrm{t} \sigma) \mathrm{Ma}$ and the three youngest an age of $1887 \pm 18$ (t $\sigma) \mathrm{Ma}$, the large uncertainty reflecting the small number of analyses pooled. The remaining zoned grains, structureless grain and high-Th/U overgrowth probably have different origins (see section7.2) but, if they are grouped, they have a mean ${ }^{207} \mathrm{~Pb} /$ ${ }^{206} \mathrm{~Pb}$ age of $1942 \pm 14$ (to) Ma.

\section{Monazite isotopic compositions}

Small amounts of monazite were recovered from the two metasedimentary gneisses Toijala- 1 and Ikaalinen-1. Ten grains were selected for analysis from the former and 7 from the latter, all high clarity and with minimal inclusions and microfractures.

The chosen grains from paragneiss Toijala1 were fine $(<80 \mu \mathrm{m}$ diameter $)$ approximately equant, somewhat rounded, anhedral and pale amber coloured. Their surfaces are relatively smooth, although with some embayments consistent with confined growth. Inclusions and microfractures are rare. No zoning is visible in transmitted light, but backscattered electron (BSE) images show each grain to consist of a patchwork of areas of different composition (Fig. 13). Two features suggest that monazite with relatively strong BSE has been replaced, in some cases almost totally, by monazite with weak BSE. Firstly, monazite with strong BSE commonly occurs towards the centres of the grains and in rare cases preserves weak growth zoning. Secondly, the boundary between the monazite with strong BSE, and structureless monazite with weak BSE is commonly convex towards the former.

The monazite grains from arkosic gneiss Ikaalinen- 1 were slightly coarser $(<100 \mu \mathrm{m} \mathrm{di-}$ ameter), but also approximately equant, anhedral and pale amber coloured. They differ from the Toijala-1 monazite grains in several ways, however. Firstly, the grain surfaces are more irregular, with sharp cuspate projections and multiple scalloped embayments. Secondly, although the grains show little fracturing in transmitted light, BSE imaging reveals some to be closely microfractured. Thirdly, BSE imaging shows very little patchy zoning. Instead most grains are either structureless or broadly growth zoned (Fig. 13), the truncation of the zones indicating that they are the remaining portions of much larger crystals. These features are consistent with the Ikaalinen-1 monazite grains being the remnants of partly dissolved coarser monazite that has been deformed but not recrystallised.

Ten U-Th- $\mathrm{Pb}$ analyses of monazite from each sample are listed in Table 2 . The monazite from Toijala-1 has a very wide range of $U$ content (190-4030 ppm) and Th/U (6.0-52.3). In contrast, the monazite from Ikaalinen-1 has a relatively uniform composition, U 4500-7300 $\mathrm{ppm}, \mathrm{Th} / \mathrm{U}$ 4.3-8.8, consistent with the relative uniformity of its BSE response. The isotopic analyses of both samples form tight clusters on a concordia diagram (Fig. 14), in both cases on average about $1.5 \%$ reverse discordant. The radiogenic ${ }^{207} \mathrm{~Pb} /{ }^{206} \mathrm{~Pb}$ in each sample is very constant, however, so the reverse discordance does not detract from the measurement of the ages. It could reflect late $\mathrm{U}$ loss from the monazite or be due to the presence of initial ${ }^{230} \mathrm{Th}$, but as the ${ }^{208} \mathrm{~Pb} /{ }^{232} \mathrm{Th}$ apparent ages are also higher than the ${ }^{207} \mathrm{~Pb} /{ }^{206} \mathrm{~Pb}$ ages, it is more likely a $\mathrm{Pb} / \mathrm{U}$ calibration error.

The ${ }^{207} \mathrm{~Pb} /{ }^{206} \mathrm{~Pb}$ measurements from the $\mathrm{To}$ ijala-1 monazite are the more dispersed because of the lower $\mathrm{Pb}$ contents and hence larger analytical uncertainties for that sample. All are equal within analytical uncertainty, however, yielding a weighted mean age of $1880.0 \pm 6.0$ (to) Ma. The monazite from Ikaalinen-1 is significantly older, with a weighted mean ${ }^{207} \mathrm{~Pb} /$ ${ }^{206} \mathrm{~Pb}$ age of $1926.1 \pm 2.9$ (to) Ma. 
Table 2. U-Th-Pb isotopic analyses of monazite from the Vammala migmatite belt, southern Finland

\begin{tabular}{|c|c|c|c|c|c|c|c|c|c|c|c|c|}
\hline $\begin{array}{c}\text { Grain } \\
\text { spot }\end{array}$ & $\begin{array}{l}\mathrm{Pb}^{*} \\
\mathrm{ppm}\end{array}$ & $\begin{array}{c}U \\
\mathrm{ppm}\end{array}$ & $\begin{array}{c}\text { Th } \\
\text { ppm }\end{array}$ & $\begin{array}{c}\mathrm{Th} / \\
\mathrm{U}\end{array}$ & $\begin{array}{l}{ }^{206} \mathrm{~Pb} / \\
{ }^{204} \mathrm{~Pb}\end{array}$ & $\begin{array}{l}\%{ }^{206} \mathrm{~Pb} \\
\text { comm.\# }\end{array}$ & $\begin{array}{c}{ }^{208} \mathrm{~Pb}^{*} / \\
{ }^{206} \mathrm{~Pb}\end{array}$ & $\pm \%$ & $\begin{array}{c}{ }^{208} \mathrm{~Pb}^{*} / \\
{ }^{232} \mathrm{Th}\end{array}$ & $\pm \%$ & $\begin{array}{c}{ }^{206} \mathrm{~Pb}^{*} / \\
{ }^{238} \mathrm{U}\end{array}$ & $\pm \%$ \\
\hline \multicolumn{13}{|c|}{ Toijala paragneiss (Toijala 1 ) } \\
\hline 3.1 & 4709 & 4033 & 38183 & 9.5 & $1.4 \mathrm{E}+05$ & 0.011 & 2.794 & 0.2 & 0.1019 & 3.0 & 0.3452 & 1.1 \\
\hline 7.1 & 3116 & 3445 & 22798 & 6.6 & $1.4 \mathrm{E}+05$ & 0.012 & 1.915 & 0.5 & 0.0999 & 3.5 & 0.3453 & 1.2 \\
\hline 4.1 & 2598 & 1091 & 25442 & 23.3 & $3.7 \mathrm{E}+04$ & 0.044 & 6.775 & 0.5 & 0.1012 & 3.6 & 0.3485 & 2.0 \\
\hline 1.1 & 731 & 831 & 4948 & 6.0 & $9.1 \mathrm{E}+04$ & 0.017 & 1.729 & 0.4 & 0.1039 & 3.9 & 0.3581 & 2.0 \\
\hline 6.1 & 1332 & 802 & 11901 & 14.8 & $1.0 \mathrm{E}+06$ & 0.001 & 4.289 & 1.6 & 0.1026 & 4.6 & 0.3550 & 3.7 \\
\hline 5.1 & 2496 & 526 & 27339 & 51.9 & $1.0 \mathrm{E}+06$ & 0.001 & 14.988 & 0.3 & 0.0980 & 3.5 & 0.3397 & 2.2 \\
\hline 10.1 & 2397 & 490 & 25665 & 52.3 & $1.4 \mathrm{E}+05$ & 0.012 & 15.286 & 0.6 & 0.1004 & 4.3 & 0.3437 & 2.8 \\
\hline 9.1 & 1736 & 452 & 18072 & 40.0 & $7.7 \mathrm{E}+04$ & 0.021 & 11.640 & 0.4 & 0.1012 & 3.4 & 0.3473 & 2.1 \\
\hline 8.1 & 1148 & 334 & 12050 & 36.1 & $1.0 \mathrm{E}+06$ & 0.002 & 10.321 & 0.9 & 0.0992 & 3.9 & 0.3466 & 2.8 \\
\hline 2.1 & 470 & 187 & 4814 & 25.8 & $1.4 \mathrm{E}+05$ & 0.011 & 7.442 & 0.6 & 0.0981 & 2.8 & 0.3395 & 1.9 \\
\hline \multicolumn{13}{|c|}{ Ikaalinen arkosic gneiss (Ikaalinen 1) } \\
\hline 1.1 & 5354 & 7308 & 31416 & 4.3 & $7.7 \mathrm{E}+04$ & 0.022 & 1.224 & 0.4 & 0.1031 & 2.8 & 0.3621 & 1.0 \\
\hline 5.2 & 5787 & 6595 & 40576 & 6.2 & $1.0 \mathrm{E}+05$ & 0.017 & 1.773 & 0.2 & 0.1012 & 3.1 & 0.3511 & 1.6 \\
\hline 6.1 & 5553 & 6012 & 40065 & 6.7 & $4.8 \mathrm{E}+04$ & 0.034 & 1.935 & 0.2 & 0.1016 & 2.4 & 0.3500 & 1.0 \\
\hline 7.1 & 6020 & 5987 & 45976 & 7.7 & $2.8 \mathrm{E}+04$ & 0.057 & 2.192 & 0.2 & 0.1003 & 2.8 & 0.3512 & 1.3 \\
\hline 2.1 & 5661 & 5907 & 40709 & 6.9 & $4.8 \mathrm{E}+04$ & 0.033 & 2.002 & 0.2 & 0.1032 & 3.0 & 0.3552 & 1.5 \\
\hline 2.2 & 5641 & 5751 & 40045 & 7.0 & $2.0 \mathrm{E}+05$ & 0.008 & 2.011 & 0.2 & 0.1047 & 3.0 & 0.3625 & 1.4 \\
\hline 5.1 & 4817 & 5240 & 32980 & 6.3 & $2.3 \mathrm{E}+04$ & 0.069 & 1.831 & 0.4 & 0.1049 & 3.0 & 0.3607 & 1.2 \\
\hline 1.2 & 5445 & 4990 & 40953 & 8.2 & $3.0 \mathrm{E}+04$ & 0.053 & 2.384 & 0.3 & 0.1047 & 3.0 & 0.3602 & 1.5 \\
\hline 4.1 & 5237 & 4878 & 40807 & 8.4 & $6.3 \mathrm{E}+04$ & 0.026 & 2.388 & 0.2 & 0.1011 & 2.8 & 0.3540 & 1.6 \\
\hline 3.1 & 4936 & 4539 & 39857 & 8.8 & $3.2 \mathrm{E}+04$ & 0.050 & 2.434 & 1.3 & 0.0981 & 3.3 & 0.3540 & 1.3 \\
\hline
\end{tabular}

\section{Interpretation of the isotopic data}

Being metasediments, both Toijala-1 and Ikaalinen-1 contain zircon of a wide range of types, compositions and ages. Most of this zircon is detrital, derived from a range of igneous, sedimentary and metamorphic protoliths. However, given that the peak metamorphic grade of the two metasediments is upper amphibolite to granulite facies, it is also to be expected that the samples will contain a small fraction of metamorphic zircon grown in situ after deposition. If the thesis is correct that the Vammala migmatite belt was metamorphosed to high grade before the widespread igneous activity and high-grade metamorphism that followed deposition of the overlying volcano-sedimentary TSB, then it is possible that some metamorphic zircon from that first post-depositional metamorphism might be preserved. Toijala-1 and Ikaalinen-1 were selected to be as free as possible from the effects of the post-TSB high-grade event, but nevertheless the challenge remains to distinguish pre- from post-
TSB metamorphic zircon, then to distinguish it in turn from detrital metamorphic zircon derived from the metasediment sources.

Monazite, on the other hand, is commonly chemically unstable under low to medium grade metamorphic conditions (e.g. Kingsbury et al., 1993; Williams, 2001), and detrital monazite, therefore, rarely survives to high grade, particularly in metapelite. Monazite present in such rocks at upper amphibolite facies and above is usually entirely metamorphic, retaining no isotopic record of its former detrital age.

Irrespective of their relation to the stratigraphic record, three metamorphic events are indicated by the present data, viz.

- $\quad 1.98 \mathrm{Ga}$, from low-Th/U overgrowths in both Toijala-1 and Ikaalinen-1.

- $\quad 1.92 \mathrm{Ga}$, from low-Th/U overgrowths in both Toijala-1 and Ikaalinen-1, and from monazite in Ikaalinen-1.

- $-1.88 \mathrm{Ga}$, from low-Th/U overgrowths in Ikaalinen-1, and from monazite in Toijala-1. 


\begin{tabular}{cccccccc}
\hline \multirow{2}{*}{${ }^{207} \mathrm{~Pb}^{*} /$} & \multicolumn{7}{c}{ Apparent Ages (Ma) } \\
\cline { 4 - 8 }${ }^{206 \mathrm{~Pb}}$ & $\pm \%$ & $208 / 232$ & \pm & $206 / 238$ & \pm & $207 / 206$ & \pm \\
\hline & & & & & & & \\
0.11513 & 0.2 & 1961 & 56 & 1911 & 18 & 1882 & 4 \\
0.11475 & 0.3 & 1925 & 65 & 1912 & 21 & 1876 & 5 \\
0.11513 & 0.7 & 1948 & 67 & 1927 & 33 & 1882 & 14 \\
0.11522 & 0.5 & 1999 & 75 & 1973 & 35 & 1883 & 9 \\
0.11433 & 0.5 & 1974 & 88 & 1958 & 63 & 1869 & 10 \\
0.11582 & 0.6 & 1890 & 63 & 1885 & 37 & 1893 & 12 \\
0.11586 & 0.8 & 1934 & 79 & 1905 & 47 & 1893 & 15 \\
0.11568 & 0.8 & 1948 & 63 & 1922 & 35 & 1891 & 14 \\
0.11550 & 1.1 & 1912 & 71 & 1918 & 47 & 1888 & 19 \\
0.11543 & 1.7 & 1891 & 52 & 1884 & 30 & 1887 & 31 \\
& & & & & & & \\
0.11845 & 0.2 & 1983 & 54 & 1992 & 17 & 1933 & 3 \\
0.11765 & 0.2 & 1948 & 58 & 1940 & 27 & 1921 & 4 \\
0.11792 & 0.2 & 1956 & 45 & 1934 & 18 & 1925 & 4 \\
0.11843 & 0.2 & 1931 & 52 & 1940 & 22 & 1933 & 4 \\
0.11787 & 0.2 & 1985 & 57 & 1960 & 25 & 1924 & 4 \\
0.11804 & 0.3 & 2013 & 57 & 1994 & 24 & 1927 & 6 \\
0.11772 & 0.2 & 2016 & 58 & 1985 & 20 & 1922 & 4 \\
0.11793 & 0.2 & 2012 & 57 & 1983 & 25 & 1925 & 4 \\
0.11818 & 0.2 & 1946 & 51 & 1954 & 27 & 1929 & 4 \\
0.11755 & 0.2 & 1892 & 60 & 1954 & 22 & 1919 & 4
\end{tabular}

The -1.88 Ga event reflects the major post-TSB thermal episode, which has been recognised in much of the Svecofennian province. The two older metamorphic events have not been recognised hitherto.

\section{I.The $~ 1.98 \mathrm{Ga}$ Event}

Zoned grains of igneous origin dominate the zircon populations in both metasedimentary samples, but distinct overgrowths are relatively common. The analyses of ten low-Th/U overgrowths in Toijala-1 identify a metamorphic event at $1978 \pm 5$ (tø) Ma. Two of three structureless grains also have low $\mathrm{Th} / \mathrm{U}$ ratios and can be attributed to the same metamorphic event.

The metamorphic age for Toijala-1 is not significantly different from the age of the main population of zoned grains at $1985 \pm 9$ (to) Ma. It is notable that a group of overgrowths has $\mathrm{Th} /$ $\mathrm{U}$ ratios intermediate between the zoned grains and the low-Th/U overgrowths. These over- growths are necessarily younger than their host grains, and must therefore be very close in age to the metamorphic overgrowths. The number of measurements is small, but it is noteworthy that none of the overgrowths, whether low or intermediate in $\mathrm{Th} / \mathrm{U}$, has an Archaean host. This may indicate that Archaean grains were not present at the site of metamorphism, but more measurements would be required to test this.

The overgrowths in Ilkaalinen-1 are similar to those in Toijala- 1 and four analyses (two with low and two with intermediate $\mathrm{Th} / \mathrm{U}$ ratios) give a mean ${ }^{207} \mathrm{~Pb} /{ }^{206} \mathrm{~Pb}$ age of $1983 \pm 14$ (to) $\mathrm{Ma}$. This indicates that the source areas of both samples were affected by the same early metamorphic event. However, while the main population of zoned grains for Tojala-1 yields an age of $1985 \pm 9$ (to) Ma, close to the age of metamorphism at $1978 \pm 5$ (t $\sigma) \mathrm{Ma}$, the main population of zoned grains in Ikaalinen-1 yields an age of $2005 \pm 9$ (to) Ma. This is suggestive of rather different source areas for the two samples, but perhaps from the same complex. Those source are- 
as were metamorphosed soon after the magmatism and prior to erosion and deposition of the present metasediment. We speculate, on the basis of the simple, coherent populations of zircons in the two samples, that the metamorphosed source complex for the VMB sediments was also relatively nearby the sites of deposition: more varied populations might be expected in far-travelled sediments. The possibility also arises that the -1.98 Ga metamorphic event was accompanied by tectonic activity that was responsible for uplift and erosion, which led to the deposition of the sedimentary protoliths of the samples soon after the metamorphic event ( $\mathrm{Ta}$ ble 3).

\subsection{The $\sim 1.92$ Ga Event}

\subsection{Correlation with VDI metamorphism}

A sub-set of eight low-Th/U overgrowths in the younger Palaeoproterozoic group from Toijala-1 gives a metamorphic age of $1916 \pm 5$ (to) Ma. The analogous sub-set of five low-Th/U overgrowths in Ikaalinen-1 gives a mean age of $1917 \pm 12$ (to) Ma. The well-dated host grains to the overgrowths are much older. Some are of similar age to the main population of zoned grains in the older Palaeoproterozoic groups and others are of Archaean age (Fig. 8). Thus this metamorphic event was superimposed on zircon from diverse, and significantly older sources. As discussed below, deposition of the metasediment protolith probably immediately postdated the -1.98 Ga metamorphism.

Both metasediment samples were selected from locations displaying only the $\mathrm{VD}_{1}$ schistosity, and the field evidence for Toijala- 1 shows that $\mathrm{VS}_{1}$ is older than the nearby granitoid, dated at $1888 \pm 5 \mathrm{Ma}$. Both areas were metamorphosed to high grade during $\mathrm{VD}_{1}$, which should have resulted in further zircon growth. The low$\mathrm{Th} / \mathrm{U}$ zircon overgrowth ages at $-1.92 \mathrm{Ga}$ are the only possibility for this $\mathrm{VD}_{1}$ metamorphic event. We therefore interpret the zircon metamorphic ages of $1916 \pm 5 \mathrm{Ma}$ and $1917 \pm 12 \mathrm{Ma}$ as recording the post-depositional $\mathrm{VD}_{1}$ metamorphism.

The evidence from the monazite in Ikaalinen-1 confirms this interpretation. All grains yield the same age, 1926.1 \pm 2.9 Ma. No older monazite is present, as would be expected if some detrital monazite were preserved. These rocks are known to have reached high grade (sillimanite-potassium feldspar, with fibrolite aggregates elongated parallel to $S_{0} / S_{1}$ planes [Kilpeläinen, 1998, p. 61]) during $\mathrm{VD}_{1}$. Monazite at such grades is usually entirely metamorphic and consequently this age can confidently be attributed to post-depositional metamorphism during $\mathrm{VD}_{1}$.

The age obtained shows that monazite recrystallisation could not take place at this locality after about $1.92 \mathrm{Ga}$ (as it did elsewhere in the VMB). This probably implies a change of conditions with uplift and erosion after $\mathrm{VD}_{1}$. As described in section 6 , the monazite appears to consist of remnants of partly dissolved coarser monazite that has been microfractured in a later event, but not recrystallised. We consider that this later event can probably be correlated with the retrogressive muscovite that occurs in this area and in other areas immediately adjacent to the TSB (Fig. 5). It can be attributed to retrograde metamorphism that may have occurred at any time after $\sim 1.92 \mathrm{Ga}$, but most probably during the subsequent metamorphism of the TSB. This interpretation is supported by previously unpublished evidence from a small gabbro body intruded into sillimanite gneiss about $7 \mathrm{~km}$ SSE of Ikaalinen-1 and about $2 \mathrm{~km} \mathrm{SW}$ of Herttuala, in the SE corner of the 1:100 000 Ikaalinen map area (Virransalo \& Vaarma, 1993; GR, 6831.55N, 2453.10E). The gabbro clearly post-dates the sillimanite metamorphism and the oldest $\mathrm{VD}_{1}$ schistosity. It is considered to represent a feeder channel of the Tampere volcanic rocks (P. Peltonen, pers. comm., 1992), and is itself deformed and metamorphosed, presumably during the post-TSB $\mathrm{TD}_{1}$ event. Thus the preservation of the $\mathrm{VD}_{1}$ monazite can be attributed 
to the locality being at a relatively high structural level during later deformation, and under retrograde conditions such that monazite again began to dissolve but was not recrystallised.

The monazite age is indistinguishable from the age of the low-Th/U zircon overgrowths in the same sample. We consider that it is undoubtedly post-depositional and that it confirms that the metamorphic age recorded in both zircon samples was also post-depositional and correlates with the observed $\mathrm{VD}_{1}$ metamorphism. It is of course possible that the metamorphic episode occupied a considerable time interval and that the zircon and monazite are recording slightly different times within that interval. However, we consider that the metamorphism is best characterised from the combined monazite and zircon data with an age of $\sim 1.92 \mathrm{Ga}$.

\subsubsection{Age of deposition of the VMB sediments}

Lahtinen et al. (2002, p. 100) have noted that evaluation of maximum deposition age should be based only on concordant analyses, preferably of several grains. This assumes that none of those grains is produced or affected by postdepositional metamorphism. Our analyses have been particularly directed at identifying postdepositional growth, so some types of zircon have been analysed that would normally have been avoided. The challenge is to distinguish concordant pre-depositional zircon from postdepositional growth and isotopic resetting (discordance).

The younger Palaeoproterozoic group in both samples is dominated by the low-Th/U overgrowths produced by post-depositional metamorphism. The groups also include a few atypical structureless or poorly zoned grains, and overgrowths with higher $\mathrm{Th} / \mathrm{U}$, but no unequivocally igneous grains. The disparate grains evidently have a range of origins, and as noted in section 5 above, they are on average slightly older (1927 $\pm 8 \mathrm{Ma}$ for Toijala- 1 , and $1942 \pm 14 \mathrm{Ma}$ for Ikaalinen-1) than the low- Th/U overgrowths $(1916 \pm 5 \mathrm{Ma}$ and $1917 \pm 12 \mathrm{Ma}$ respectively).
The structureless grain 13 in Toijala-1 (Fig. 8) has a low $\mathrm{Th} / \mathrm{U}$ ratio and gives an age of $1932 \pm 9 \mathrm{Ma}$. As with the structureless grains associated with the -1.98 Ga metamorphism, this grain can be attributed to growth during the same metamorphic event as produced the low$\mathrm{Th} / \mathrm{U}$ overgrowths. Similarly, the overgrowths 28.1 and 10.1 , with intermediate $\mathrm{Th} / \mathrm{U}$ ratios and ages of $1926 \pm 5 \mathrm{Ma}$ and $1926 \pm 9$ Ma respectively, can also be attributed to growth closely associated with the post-depositional metamorphism. Those zoned grains with similar apparent ages (e.g. 12.1 and 9.1) are U-rich and probably isotopically disturbed. Such disturbance is evident in the disparity between the ages measured on the core of grain 28 .

The ages measured on the analogous subgroup in Ikaalinen- 1 can be similarly explained. One structureless grain (19, Fig. 8) gives a similar discordant age within error $(1940 \pm 8 \mathrm{Ma})$ to grain 13 in Toijala-1, but has a high $\mathrm{Th} / \mathrm{U}$ ratio. The core of grain 14.2 (Fig. 8) is very weakly zoned, but has a very low $\mathrm{Th} / \mathrm{U}$ ratio and yields $1926 \pm 9$ Ma. Overgrowth analysis 11.2 with intermediate $\mathrm{Th} / \mathrm{U}$ is strongly discordant and gives an age of $1935 \pm 23 \mathrm{Ma}$.

We therefore interpret the analyses of overgrowths and structureless grains in both samples as representing post-depositional growth during the onset of the $\sim 1.92$ Ga metamorphism, analogous to the similar grains seen in association with the $-1.98 \mathrm{Ga}$ metamorphism. The few associated ages from zoned grains, mainly discordant and high $\mathrm{U}$, we interpret as affected by isotopic resetting. As they include no analyses of normal well-zoned concordant igneous grains, we consider that they do not bear on the maximum age of deposition. The sediment must have been deposited after $-1.98 \mathrm{Ga}$, the age of the youngest group of igneous detrital cores. It must have been deposited before the $-1.92 \mathrm{Ga}$ post-depositional metamorphism.

We have noted above that the more nearly concordant zoned grains in the older Proterozoic populations form groups older than the $-1.98 \mathrm{Ga}$ metamorphism. The lowest age 
in the total Toijala- 1 population is $1964 \pm 6$ from grain 11.1, but this analysis shows high $\mathrm{U}$, is strongly discordant and also has an unusually low $\mathrm{Th} / \mathrm{U}$ ratio. $\mathrm{Pb}$ loss is a real possibility. There are no concordant zoned igneous grains definitely younger than the $-1.98 \mathrm{Ga}$ metamorphism. Thus the VMB protoliths do not appear to have sampled any zircon-bearing source areas aged 1.97-1.93 Ga, and they were probably deposited soon after the $\sim 1.98$ Ga metamorphism. Significantly, deposition of the sediments after $\sim 1.97 \mathrm{Ga}$ would allow the associated mafic rocks in the south of the VMB to represent an extensional episode of similar age to the 1.95-1.96 Ga Outokumpu and Jormua ophiolites.

In summary therefore both samples indicate a maximum deposition age of $\sim 1.97 \mathrm{Ga}$, a minimum of $-1.93 \mathrm{Ga}$, and post-depositional metamorphism at $-1.92 \mathrm{Ga}$. Thus the protoliths of the VMB are markedly different from the older sediments of the Bothnian Basin, which have been inferred to have a maximum deposition age of $-1.91-1.92 \mathrm{Ga}$ and which commonly contain significant detrital populations (measured on near concordant igneous grains) younger than $-1.95 \mathrm{Ga}$ (Claesson et al., 1993, Lahtinen et al., 2002, both including discussion of sample A1, the location of which is shown on Fig. 3, and also sample A57 in the TSB).

\subsubsection{Relation of the $\sim 1.92 \mathrm{Ga}$ metamorphism to the TSB and Haveri sequences}

The $\mathrm{VD}_{1}$ metamorphic episode at $-1.92 \mathrm{Ga}$ is older than the whole of the TSB volcanic sequence, which has yielded a maximum age of $1904 \pm 4$ Ma near the base (Kähkönen et al., 1989). This in itself invalidates the earlier conclusion that the "migmatite area was merely a marine part of the Tampere island arc formation" (Kilpeläinen et al., 1994, p. 27).

The youngest detrital zircons (e.g. $1907 \pm 15$ Ma, Huhma et al., 199l) from the greywackes of the Myllyniemi formation underlying the volcanics have been considered to indicate max- imum deposition ages of "about 1.92-1.91 Ga"(Lahtinen et al., 1992, p. 100), and to imply that deposition "took place c. 1.9 Ga shortly before the felsic volcanism" (Huhma et al., 1991, p. 176; cf. Nironen, 2004; Kähkönen et al., 2004). While the uncertainties in the available data would allow an older maximum deposition age, we consider that the published interpretations are reasonable. They are supported by (1) the conformable and interfingering relationship between the greywackes and the dated volcanics (2) the presence in these rocks of only the same post-TSB deformation as in the overlying volcanic sequences and, conversely, (3) the absence of the complex folding and of the $\mathrm{VD}_{1}$ schistosity, which are present throughout the VMB. Most importantly, however, it can now be added that, in the SE Ikaalinen area from which sample Ikaalinen-1 was taken, the VMB actually underlies the TSB succession with discordant contacts (section 2.3 above). Thus, the date of $-1.92 \mathrm{Ga}$ obtained for the $\mathrm{VD}_{1}$ metamorphism there itself provides a maximum deposition age for the overlying TSB sediments. The previously inferred maximum deposition age for the Myllyniemi Formation is just what would be expected if the greywackes of that formation were the result of uplift and erosion following the crustal shortening associated with the $\mathrm{VD}_{1}$ event. The upward-fining trend in these sediments accords well with this interpretation.

The Myllyniemi formation has been correlated with the Osara formation, a smaller area of metaturbidites and migmatitic metaturbidites to the NW of the main synclinal depression (Fig. 3; Kähkönen, 1999, p. 17). The Osara formation appears to be underlain conformably by the basalts of the Haveri Formation, regarded as the oldest unit in the TSB (Kähkönen \& Nironen, 1994). The latter authors showed that these basalts have marginal basin affinities and suggested (op. cit., pp. 156-157) that they might represent an "ensialic, relatively small, extensional basin, floored by attenuated (Palaeoproterozoic) continental crust." They (op. cit., p. 158) did not favour a protracted evolution- 
ary history, and considered that "tholeiitic mafic volcanism in an extensional setting was followed, possibly continuously, by arc-type magmatism".

The ages of the Osara and Haveri formations are not well established, however. The contact with the overlying Harhala Formation is not exposed, but in accordance with their view that the Haveri and Osara formations are closely associated in time with the overlying arc volcanics, Kähkönen \& Nironen, (1994, p. 146) correlated the earliest schistosity in the Haveri district with $\mathrm{TS}_{1}$ in the central TSB. If this is correct, the Osara and Haveri formations may well be younger than $-1.91 \mathrm{Ga}$, but the structural pattern is relatively complex. The three deformation episodes identified (op. cit.) are comparable in style with the three episodes recognised in the VMB (Kilpeläinen, 1998). $S_{1}$ is layer parallel and apparently not related to upright folding. Migmatitic mica gneisses occur adjacent to the overlying Harhala formation of the TSB, and the metamorphism has affinities with that of the SW Ikaalinen area of the VMB (Fig. 5). The main folding is $\mathrm{F}_{2}$, while open $\mathrm{F}_{3}$ folds are sub-parallel to the contact with the Harhala formation. We suggest therefore that $\mathrm{F}_{3}$ correlates with $\mathrm{TS}_{1}$ in the TSB and that these rocks represent a relatively low-grade part of the VMB.

Vaasjoki \& Huhma (1999) observed that the least radiogenic leads at Haveri and in the $\mathrm{Ou}$ tokumpu ophiolite complex are similar "and the two occurrences can be coeval". Their lead isotope data yields "rather uncertain age estimates in the 1900-2000 Ma range", which are consistent with the possible correlation but which they observe cannot be treated as true ages. We have suggested above (section 7.2) that our sampled VMB sediments may have been deposited as early as $\sim 1.97 \mathrm{Ga}$ and that such a depositional age would allow the associated mafic rocks in the VMB proper to be of similar age to the 1.96-1.95 Ga Outokumpu and Jormua ophiolites. It is possible therefore that the Haveri basalts could also be of this age, consistent with the $\mathrm{Pb}$ isotope data. They would then also rep- resent an extensional episode in the evolution of the Svionian Basin and the correlation with the above ophiolites, canvassed by Vaasjoki \& Huhma (e.g. 1999, p. 151) becomes geologically plausible. Further work would be required to test this possibility, but we tentatively interpret the Haveri and Osara formations to be part of the pre-1.92 Ga VMB. If this is correct it reinforces the conclusion that the true TSB succession is younger than $-1.92 \mathrm{Ga}$.

It follows from this conclusion and the dating of $\mathrm{VD}_{1}$ that the widely accepted stratigraphic correlation between the turbidites of the TSB (the Myllyniemi formation) and the metasediments in the north of the VMB cannot be sustained. This correlation was largely based on lithological and geochemical similarities (Lahtinen, 1996), and it can be suggested instead that these similarities are a consequence of the derivation of the TSB turbidites from the erosion of the upper parts of the VMB complex.

\subsection{The $\sim 1.88 \mathrm{Ga}$ Event.}

The monazite from Toijala-1 records a thermal event at $1880.0 \pm 6.0 \mathrm{Ma}$. As described above, this monazite is chemically variable and texturally different from that in Ikaalinen-1, consistent with almost total replacement of an earlier monazite. It possibly replaced an older metamorphic monazite that was formed during the earlier $\sim 1.92 \mathrm{Ga} \mathrm{VD}_{1}$ metamorphism recorded in the zircon data, and in the Ikaalinen-1 monazite data. The possibly original monazite (e.g. 5.1, Fig. 8), however, appears to preserve no isotopic record of that event.

The $-1.88 \mathrm{Ga}$ event is not recorded in the zircon from Toijala- 1 . The sample was selected from a location where the early $\mathrm{VD}_{1}$ schistosity was dominant. Younger leucosome veins are present as a conjugate network crosscutting the schistosity, but were avoided in sampling. Perhaps the $-1.88 \mathrm{Ga}$ event did not produce new zircon growth because fluids, associated with the veins, were unable to penetrate the rather fine- 
grained schistosity, in the absence of coeval penetrative deformation.

A weak indication of the $-1.88 \mathrm{Ga}$ event is present in Ikaalinen-1 zircons. The three youngest $\mathrm{Th} / \mathrm{U}$ overgrowths form a separate group with a mean age of $1887 \pm 18 \mathrm{Ma}$, although two of the analyses are discordant and the other has a large analytical uncertainty. One of these overgrowths (11.1) is superimposed on an older overgrowth (11.2) of the -1.92 Ga metamorphic generation (Fig. 8), and therefore clearly records a younger event. If these overgrowths do represent the $-1.88 \mathrm{Ga}$ event, they can probably be attributed to fluid access to this coarsegrained metasediment at this time, associated with $\mathrm{TD}_{1}$ migmatisation around major intrusions to the west.

As outlined in section 2.1 , an age of $\sim 1.88 \mathrm{Ga}$ can be inferred for emplacement of plutons and the $\mathrm{TD}_{1}$ folding and metamorphism in the TSB (Nironen, 1989b). This age correlates closely with the thermal event age of $1880.0 \pm 6.0 \mathrm{Ma}$ obtained from the Toijala-1 monazite in the area of the VMB characterised by the garnet sillimanite association (Fig. 5). Monazites dated by Mouri et al. (1999) from mesosomes and leucosomes in VMB migmatites at Luopioinen, about $20 \mathrm{~km}$ ESE of Tampere, gave a similar mean age of $1878.5 \pm 1.5 \mathrm{Ma}$. These migmatites are characterised by the sillimanite + cordierite \pm garnet association, which is largely restricted to the Tampere map sheet (Fig. 5), and probably represents a higher structural level.

We infer that the close correspondence in monazite ages between the TSB and VMB events at different structural levels implies that uplift and cooling took place rather rapidly after the deformation of the TSB. As noted in section 2.1, the south-side-up shear zone, which separates the TSB from the VMB (Fig. 3), is essentially a $\mathrm{TD}_{1}$ structure (Nironen, 1989a, p. 31) and could account for rapid decompression and cooling as uplift and erosion of the VMB occurred. We therefore conclude that the monazite ages of $\sim 1.88 \mathrm{Ga}$ in the VMB correspond closely to the age of peak metamorphism in the TSB.

\subsection{Relationship of ages to evolution of meta- morphism and migmatisation}

In their study of migmatites in the VMB, Mouri et al. (1999) found agreement in age within sometimes large error margins between $\mathrm{U}-\mathrm{Pb}$ dating of monazite, limited SIMS dating of unzoned overgrowths on zircon, and Sm-Nd garnet-whole rock analyses. They suggested "that the migmatites were metamorphosed at ca. 1880 Ma during a single metamorphic event. Since there is no evidence of an earlier event in the study area, it is assumed that $1880 \mathrm{Ma}$ is the approximate age of the peak metamorphic event." However, only the monazite yielded a precise age, and there now is evidence of an earlier event: the various metamorphic assemblages in the region clearly span a 40 m.y. period between the metamorphism at $-1.92 \mathrm{Ga}$ in the VMB and the peak metamorphism and deformation in the TSB at $-1.88 \mathrm{Ga}$. A full re-evaluation of that metamorphic history is beyond the scope of this paper but some suggestions can be made to reconcile the new evidence with that of Mouri et al. (1999).

We have chosen VMB samples in which only the earliest schistosity $\left(\mathrm{VD}_{1}\right)$, parallel to lithological layering, is present, and where the influence of younger events is apparently minimal. This has allowed the identification of a post-depositional metamorphic event at $-1.92 \mathrm{Ga}$ and its correlation with the metamorphism accompanying $\mathrm{VD}_{1}$. Sillimanite and garnet both formed early (Kilpeläinen, 1998, pp. 96-97), and are considered to be coeval with $\mathrm{VD}_{1}$, as are the thin bands of concordant leucosome. The local field evidence shows that the $\mathrm{VD}_{1}$ metamorphism occurred before the emplacement of the Toijala2 granitoid at $1888 \pm 5 \mathrm{Ma}$; and both the geochronology and the broader structural evidence discussed above suggest that the earliest schistosity was formed before the TSB succession was deposited. The existence of an early (Svionian) metamorphism is therefore well established.

In contrast, Mouri et al. (1999) selected samples to study the migmatisation that is superimposed on the earliest schistosity and their data are dominated by the younger events. It is likely 
Table 3. Summary of isotopic results and interpretations

\begin{tabular}{|c|c|c|}
\hline Zircon & Toijala-1 & Ikaalinen-1 \\
\hline Pre-depositional Archaean & Fewer at $\mathbf{- 2 . 7 2} \mathbf{G a}$ & More at $-2.92-2.44 \mathrm{Ga}$. \\
\hline \multicolumn{3}{|c|}{ Absence of $2.4-2.1$ Ga detrital grains } \\
\hline $\begin{array}{l}\text { Pre-depositional older Palaeoproter- } \\
\text { ozoic }\end{array}$ & $\begin{array}{l}\text { Igneous complex } \\
\text { (Within or on margin of older-stage } \\
\text { Svionian basin?) at } \boldsymbol{- 1 . 9 9} \mathbf{~ G a} \\
\text { Metamorphism at } \sim \mathbf{1 . 9 8} \mathbf{~ G a}\end{array}$ & $\begin{array}{l}\text { Igneous complex } \\
\text { (Within or on margin of older-stage } \\
\text { Svionian basin?) at } \mathbf{- 2 . 0 1} \mathbf{~ G a} \\
\text { Metamorphism at } \mathbf{- 1 . 9 8} \mathbf{~ G a}\end{array}$ \\
\hline \multicolumn{3}{|c|}{ Absence of post-1.97 Ga detrital igneous grains } \\
\hline Post-depositional Palaeoproterozoic & $\begin{array}{l}\text { Early metamorphic? at } \sim \mathbf{1 . 9 3} \mathbf{~ G a} \\
\text { Metamorphism and } \mathrm{VD}_{\text {at }} \boldsymbol{- 1 . 9 2} \mathbf{~ G a}\end{array}$ & $\begin{array}{l}\text { Early metamorphic? at } \sim \mathbf{1 . 9 4} \mathbf{G a} \\
\text { Metamorphism and } \mathrm{VD}_{1} \text { at } \sim \mathbf{1 . 9 2} \mathrm{Ga}\end{array}$ \\
\hline Monazite & & Metamorphism and $\mathrm{VD}_{1}$ at $\sim 1.93 \mathrm{Ga}$ \\
\hline \multicolumn{3}{|c|}{$\begin{array}{l}\text { Unconformity above } V M B \\
\text { Deposition of } T S B \text { succession between } \mathrm{VD}_{1} \text { and } \mathrm{TD}_{1} \text {. } \\
\text { Intrusion of post- } \mathrm{VD}_{1} \text { Toijala-2 granitoid at } \mathbf{1 . 8 9} \mathbf{G a}\end{array}$} \\
\hline Monazite & Metamorphism and $\mathbf{T D}_{1}$ at $\sim \mathbf{1 . 8 8} \mathbf{~ G a}$ & \\
\hline
\end{tabular}

in the regional context that the earliest schistosity observed was initiated as $\mathrm{VD}_{1}$, but this is not certain, as the schistosity was not demonstrated to be parallel to lithological layering. Similarly, it is not certain that the earliest leucosome vein L1 studied by Mouri et al. was coeval with $\mathrm{VD}_{1}$. In any case, the mesosome assemblage was clearly modified by younger events (op. cit., p. 34), most notably the development of cordierite coronas around garnet. Cordierite does not occur in the earliest concordant leucosome, L1, nor in the discordant L2 leucosome, but it does occur in rare small L3 leucosome patches overprinting the main foliation.

Mouri et al. (op. cit., p. 38) consider that 'the textures observed in the mesosome and the formation of the different types of leucosomes can be explained by progressive partial melting reactions during increasing temperature and decompression.' They evidently assume that partial melting and the formation of the different leucosome generations occurred very shortly before the peak metamorphic event but the available evidence does not require this.

Mouri et al. (op. cit., pp. 39-40) consider that both the L1 and the L2 leucosome melts were produced along with garnet before the appearance of cordierite in the assemblages. However no zircons, among the limited number of SIMS measurements, were specifically identified as being associated with these magmat- ic events. Some weakly oscillatory-zoned rims were considered to be of magmatic origin and two of these in the L1 leucosome gave ages of $1904 \pm 17 \mathrm{Ma}$ and $1915 \pm 9 \mathrm{Ma}$. A further metamorphic overgrowth in the mesosome gave an age of $1907 \pm 8 \mathrm{Ma}$. These were discounted as possibly mixed ages by Mouri et al., but it now seems possible that they represent the early (Svionian) metamorphism and melt formation. It is also notable that IDTIMS zircon ages indicated for the L1 and L2 leucosomes were strikingly different at $1950 \mathrm{Ma}$ and $1892 \mathrm{Ma}$, and, if the ages reflect mixed age populations (cf. op. cit., p. 47), these were evidently very different. Since the peak metamorphic event affected both the leucosomes (op. cit., pp. 47 and 51), it apparently correlates with the L3 event or later. We therefore consider that the data presented by Mouri et al. (1999) allows an extended metamorphic history before their peak metamorphic event.

At deeper levels in the migmatites, recrystallisation of monazite occurred during the -1.88 Ga metamorphic episode to produce the monazite of Toijala- 1 and of the samples studied by Mouri et al. (op. cit.) at $\sim 1.88 \mathrm{Ga}$. We have inferred above that this age corresponds closely to the age of peak metamorphism (Bothnian) in the TSB, which accompanied the post-depositional folding. The age of $1888 \pm 5 \mathrm{Ma}$ obtained from the Toijala-2 quartz diorite is very similar to the monazite ages, and also to the age of vol- 
canics in the upper part of the TSB succession (1889 5 Ma, Kähkönen et al., 1989), and to the age of granitoid clasts in that succession (Nironen, 1989b). The geological evidence therefore shows that granitoid emplacement, uplift, erosion and conglomerate deposition, all took place during the later part of volcanic activity in the TSB at $-1.89 \mathrm{Ga}$. The granitoids in the VMB are closely associated with migmatisation in their contact zones and it therefore appears that the younger (Bothnian) metamorphic episode in the VMB began at least as early as $\sim 1.89$ Ga. It may have begun earlier at $-1.90 \mathrm{Ga}$, as indicated by the early felsic volcanism dated at $1904 \pm 4 \mathrm{Ma}$ in the overlying TSB. We therefore suggest that in the deeper levels of the VMB, renewed metamorphism and migmatisation probably occurred during an extended period between -1.90 and $1.88 \mathrm{Ma}$.

In this geological context, the discordant L2 leucosomes were probably generated in association with the major granitoid intrusions at -1.89 Ga. Formation of the concordant L1 leucosome may have occurred during the early stages of the renewed metamorphism, or it may have occurred during Svionian metamorphism as indicated by the limited SIMS data noted above. The latter would require an hiatus before the discordant L2 leucosomes were generated.

We suggest that the later, post- L2, stages of evolution involving cordierite growth after garnet, and the production of cordierite plus melt (Mouri et al., 1999, p. 39), were probably contingent on the decompression of the subjacent VMB implied by the uplift and erosion at $\sim 1.89$ Ga recorded in the TSB. This implies that the formation of the L1 and L2 leucosomes took place before this uplift. On the other hand, the monazite ages of $-1.88 \mathrm{Ga}$ in the VMB correspond closely to the age of peak metamorphism in the TSB, which followed the deposition of the whole TSB succession. We therefore suggest that, in order to give the ages obtained, equilibration of the Sm-Nd garnet-whole rock and U-Pb monazite systems studied by Mouri et al. must have occurred during these later stages of migm- atite evolution, when the temperature probably remained above $700^{\circ} \mathrm{C}$ (op. cit., p. 41).

Some granitoid emplacement accompanied the upright $\mathrm{TD}_{1}$ folding and peak metamorphism in the TSB (Nironen, 1989a). The youngest L-granite of Mouri et al. (op. cit., pp. 36 and 46) was probably intruded at this stage. The granite is sillimanite-bearing and it preserves the same monazite age as the geologically older samples. This confirms the correlation of the monazite ages with the post-TSB metamorphism.

The principal conclusions from Section 7 above are summarised in Table 3, which also incorporates some conclusions from the following discussion.

\section{Discussion: implications for Sve- cofennian tectonics}

The most important conclusions from our data and interpretations are:

1) The VMB has a pre-1.92 Ga history of sedimentary basin development probably extending back to $-1.97 \mathrm{Ga}$, which has not previously been recognised. The detrital zircon population provides evidence of a predepositional metamorphic episode at $\sim 1.98$ $\mathrm{Ga}$ and of $-2.1-1.98 \mathrm{Ga}$ source complexes.

2) A major episode of deformation and metamorphism occurred at -1.92 Ga before the deposition of the TSB succession.

3) The TSB succession was deposited on the VMB basement in the 40 m.y. interval between the tectonothermal episodes at -1.92 Ga and $\sim 1.88 \mathrm{Ga}$.

Each of these conclusions (see also Table 3) bears on the interpretation of the tectonic relationship of the VMB to adjacent tectonic domains, and also has wider implications for the evolution of the Svecofennian Province as a whole.

\section{I. Source of detrital zircons and two-stage ba- sin evolution}

Previous studies of detrital zircon in sediments 
of the Bothnian Basin (Huhma et al., 1991; Claesson et al., 1993; Welin et al., 1993) revealed that 2.1-1.9 Ga source areas were dominant, but the location of these was problematic (e.g. Kähkönen, 1999, p. 27). Possible source areas of this age are not known in the adjacent Karelian Province in Finland. The present study is the first test of the hypothesis (Rutland et al., 2001b, p. 256) that the postulated pre-1.9 Ga metamorphic complexes were the principal source, and does show that the VMB rocks contain appropriate zircon populations.

As suggested in section 7.1 the source complexes of the VMB sediments were probably not far distant from the sites of deposition. It is therefore possible that these source complexes were themselves located within the Svionian marginal basin. Possibly they were located in island arcs separating the basin into a complex of back-arc and intra arc basins. The recognition that the source complexes for the VMB sediments were metamorphosed at $-1.98 \mathrm{Ga}$ also suggests that there may have been simultaneous tectonic activity which might separate basin evolution into older and younger stages, and which might correspond to accretion of an older $(-2.1-1.98 \mathrm{Ga})$ stage. As suggested above (section 7.2), the associated mafic rocks in the younger stage basin $(-1.97-1.92 \mathrm{Ga})$, notably in the south of the VMB, and possibly at Haveri, could represent a renewed phase of extension that can be tentatively correlated with the Outokumpu and Jormua ophiolites. Thus the proposed two stages of evolution of the Svionian Basin appear to correspond broadly in age (but not in detrital zircon content) to the Lower and Upper Kalevian tectofacies on the Karelian craton margin (Kohonen, 1995, pp. 62-68), which are also separated in age by the ophiolites.

The presence of granitoids as old as $1.96 \mathrm{Ga}$, intruding older, previously deformed, sequences in some parts of the Svecofennian in Sweden (Wasström, 1993; 1996; Claesson \& Lundqvist, 1995) gives some direct support to the existence of the proposed older stage basin. Indeed, the early deformation of the Storuman sub-zone of Rutland et al. (2001b, Fig. 3 and p. 232) may reflect the $\sim 1.98 \mathrm{Ga}$ event, and the younger stage of Svionian Basin development may be absent in that area. An older stage basin also appears to be present in the basement of the East European Platform, $-500 \mathrm{~km}$ to the SSE of the Tampere district (Claesson et al., 2001), where rocks $2.10-1.95 \mathrm{Ga}$ old are known from drill hole samples. The concealed NE-trending $\mathrm{Ar}-$ chaean-Palaeoproterozoic boundary there (Fig. 1) appears to have quite different characteristics (e.g. Bogdanova et al., 1996; Claesson et al., 2001) from the NW trending boundary in Finland. It is marked by a wide $-2.0-2.1 \mathrm{Ga}$ volcano-plutonic belt (the Osnitsk-Mikashevichi Igneous Belt, OMB) and by -2.1 Ga granulite facies metamorphism in metasediments overlying the Archaean craton of Sarmatia to the SW.

The trends of the Palaeoproterozoic belts to the NW of Sarmatia are roughly parallel to the cratonic margin in the south, but bend northwestwards or even westwards approaching the Gulf of Finland (Fig. 1). This Palaeoproterozoic province is apparently dominated by metasediments that contain detritus significantly older than the orogenic deformation and metamorphism. The range of initial $\varepsilon_{\mathrm{Nd}}$ values is similar to that found in Svecofennian metasediments (Claesson et al., 2001, p. 14), and these sediments can reasonably be interpreted as marginal basin fill. In the context of a marginal basin interpretation, the $\mathrm{OMB}$ can then be compared with the Cenozoic Sikhote-Alin Belt on the margin of the Chinese craton, inboard of the Japan Sea marginal basin (e.g. Okamura et al., 1998), rather than with an Andean belt.

An older Palaeoproterozoic domain (the Vitebsk Granulite Domain) adjacent to the craton displays was metamorphosed to granulite facies at $-1.96 \mathrm{Ga}$, but is considered to have a crust formation age of $-2.0 \mathrm{Ga}$ (Claesson et al., 2001, p.15). It could therefore represent an early phase of marginal basin development that was accreted by $1.96 \mathrm{Ga}$, and correspond to our proposed older stage Svionian Basin. It is presumably rich in detritus from the $-2.1-2.0 \mathrm{Ga} \mathrm{OMB}$ 
volcano-plutonic belt. This basin may have been bounded to the west by the $-1.98 \mathrm{Ga}$ Okolovo volcanic belt (Fig. 1), which has yielded $\mathrm{U}-\mathrm{Pb}$ ages of $1982 \pm 26 \mathrm{Ma}$ and $1998 \pm 10 \mathrm{Ma}$ from juvenile metadacites (similar to the ages of the main detrital populations in our Toijala-1 and Ikaalinen-1 samples from the VMB). A metamorphic age of $-1.92 \mathrm{Ga}$ (op. cit., p. 10), like that of the VMB, has also been obtained from this volcanic belt.

Thus, the OMB and the pre-1.96 Ga domains adjacent to it seem to offer potential source areas for 2.10-1.98 Ga (and Archaean) zircons in sediments of the younger stage of Svionian Basin development, as exemplified by the VMB. However, the indications are that similar, but undated, rocks extend northwards to the Gulf of Finland (Fig. 1; Claesson et al., 2001, Fig. 1; Bogdanova et al., 1996, Fig. 7.2a). Kostinen et al. (1996, pp. 51-52) consider that the structures south of the Gulf appear to represent a continuation of Svecofennian structures from the southern Finland coastal area. They regard the land-Paldiski-Pskov shear zone, which forms the SW boundary of this pre-1.96 Ga domain (and the NE boundary of the younger Belarus-Baltic Granulite belt, BBG, Fig. 1) where it crosses the Gulf of Finland, as one of the most important internal boundaries within the Svecofennian Domain. The available geological evidence therefore suggests that a similar older Palaeoproterozoic domain may form the proposed early stage of Svionian Basin development in the Svecofennian province proper (e.g. beneath the LGSM and the CFGC, Fig. 15) and thus offer a more local source for the VMB detrital zircons.

\subsection{The Early Svecofennian deformation}

The most significant of our conclusions is that the metamorphic event in the VMB at -1.92 Ga post-dated deposition of the sedimentary protoliths of the VMB and correlates with the observed $\mathrm{VD}_{1}$ metamorphism (section 7.2). In the Skellefte district, $\mathrm{D}_{1}$ could be dated only approximately by the available evidence as old- er than $-1.90 \mathrm{Ga}$. We shall refer to this widespread deformation as Early Svecofennian $\left(D_{E}\right)$, acknowledging that it may be somewhat diachronous. Daly et al. (2001) show that the principal deformation and metamorphism associated with accretion in the Lapland-Kola Orogen also took place before $\sim 1.91 \mathrm{Ga}$. The age of -1.92 Ga now obtained for the Early Svecofennian $\left(D_{E}\right)$ deformation therefore reinforces the suggestion (Rutland et al., 2001, p. 256) that it could be related to the collision that produced the Lapland Granulite Belt to the north of the Karelian Province (Fig. 1).

The dating of $\mathrm{VD}_{1}$ also strongly supports the marginal basin accretion hypothesis for the $\mathrm{VMB}$, and rules out various earlier tectonic interpretations of the VMB based on the assumptions that the protolith sediments and the subsequent deformation and metamorphism were post-1.91 Ga. The sediments in the north of the VMB can no longer be interpreted as a fore arc (Lahtinen 1996, p. 43), or accretionary complex (Kähkönen, 1999, pp. 26-27) closely related in time to the TSB; and the main structures in the $\mathrm{VMB}$, including the suggested suture in the south of the VMB (e.g. Kähkönen et al., 1994, Fig. 1; Lahtinen, 1996, p. 95), can no longer be interpreted as due to accretion at $\sim 1.89 \mathrm{Ga}$.

The inference that $\mathrm{a}-1.89$ Ga suture might exist between the TSB and the Hämeenlinna-Somero Volcanic Belt (HSB, Hakkarainen, 1994) to the south (Fig. 15) was based on the assumed age of the $\mathrm{VMB}$, and on the presence of MORB-affinity volcanics and DM-affinity mafic plutonics near its sheared southern margin. We have now shown that the VMB is older than $-1.92 \mathrm{Ga}$ and that such mafic rocks may be as old as $1.97 \mathrm{Ga}$ (section 7.2.). If they are indicative of a suture rather than within-plate extension, subduction may have occurred during closure of the basin at $-1.92 \mathrm{Ga}$, but if so, it

Fig. 15. Geological map of southern Finland (simplified from Korsman et al., 1997) showing the principal volcanic sequences and other tectonic elements discussed in the text, and also showing the location of Fig. 3. 


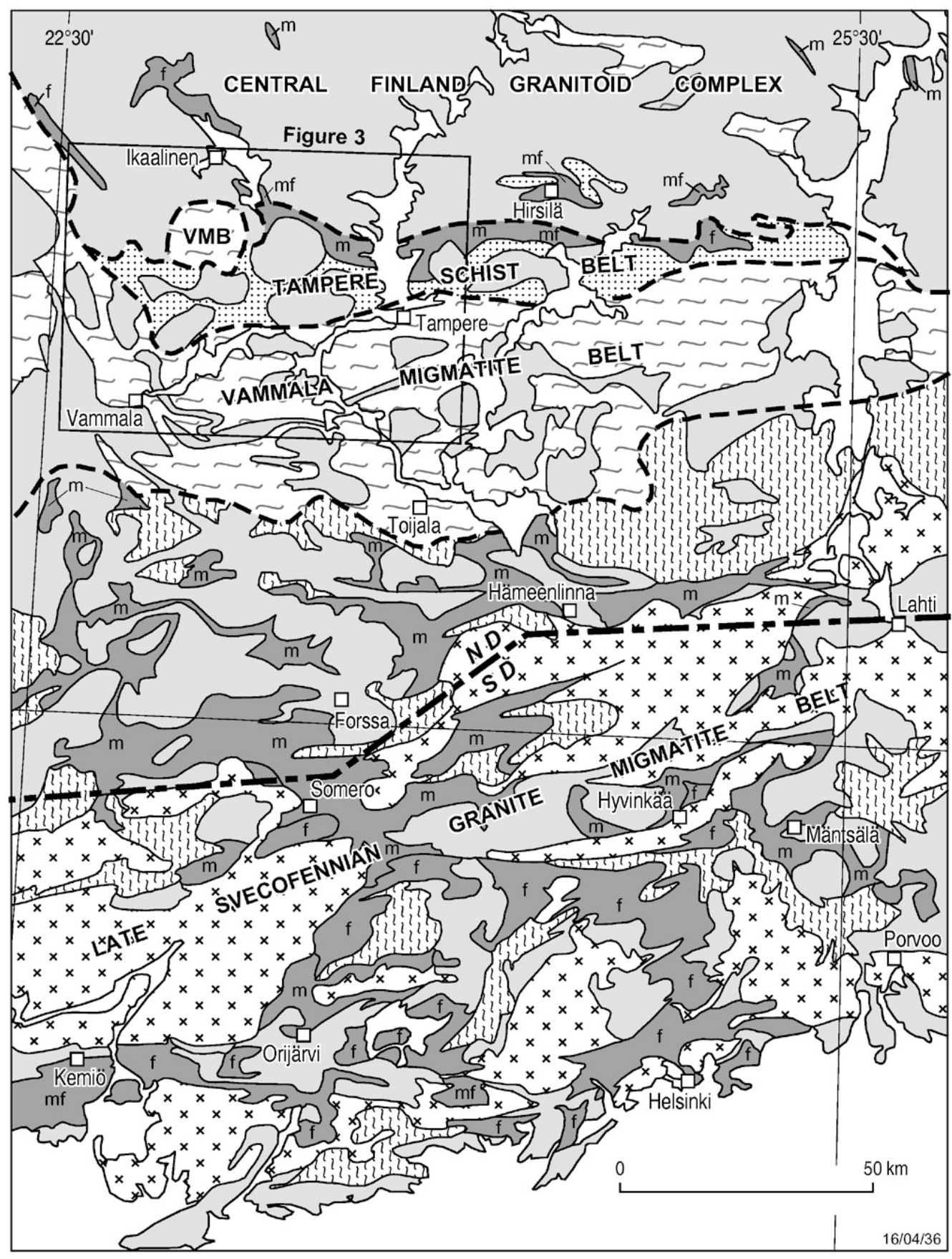

$\mathrm{m} / \mathrm{f}$ Volcanic complexes $m=$ mafic $f=$ felsic

li?

Undifferentiated older granitoids, $1.89-1.87 \mathrm{Ga}$

$\left[\begin{array}{l}x \\ \times \\ x\end{array}\right]$ Younger granites, $1.84-1.82 \mathrm{Ga}$
Greywackes,schists and conglomerates in TSB

Vammala Migmatite Belt

- Boundary between northern volcanic domain (ND) and southern volcanic domain (SD) 
occurred before the deposition of the overlying TSB and HSB. Thus, there now seems to be little justification for postulating subduction and an arc-accretionary episode at 1.89-1.88 Ga (e.g. Lahtinen, 1994, p. 109 \& Fig. 29), or later (Väisänen et al., 2002).

It is evident that the VMB is largely responsible for the crustal scale Southern Finland electrical conductive belt (e.g. Korja et al., 1993, Figs. $5 \& 8$ ). This and other such belts were previously interpreted as resulting from collisions post1.9 Ga. As in the Skellefte area (cf. Rutland et al. 2001a, pp. 233-234), these belts can now be related to the pre-1.90-1.92 Ga metamorphic complexes. The continuity of these belts provides good evidence of the continuity of the metamorphic complexes (Fig. 2), and therefore, for the concept of an extensive pre-1.92 Ga Svionian Basin. Nironen at al. (2002) do not show a boundary between their Pirkanmaa (including the VMB) and Pohjanmaa (WBB in Fig. 2) belts. Koistinen et al. (1996, p. 28 and Fig. 1) also suggest that extensions of their Tonalite Migmatite Zone (of which the VMB is a part) link eastwards to the Haukivesi-Savonlinna area and to the Sortavala region northwest of Lake Ladoga.

We therefore now infer that the main crustal thickening took place at -1.92 Ga during the closure of the younger stage Svionian Basin, rather than at $-1.89 \mathrm{Ga}$ as proposed in the arcaccretionary model. Subduction zones may have been involved in the accretion process and pre$1.91 \mathrm{Ga}$ sutures and/or major $\mathrm{D}_{\mathrm{E}}$ thrust structures may therefore be present. Rutland et al., (2001a) suggested that the earliest deformation phase $\left(D_{E 1}\right)$ could perhaps be directly responsible for the deep seismic reflectors, interpreted as a fossil subduction zone, in BABEL profiles 3 and 4 (BABEL Working Group, 1990; 1993). The NE dip of this zone is consistent with the direction of $\mathrm{D}_{\mathrm{E} 1}$ thrusting onto the adjacent Karelian craton. In the arc accretion models this earliest deformation has been attributed to accretion of the earliest arc complex through subduction either towards or away from the craton (e.g., Ekdahl, 1993; Lahtinen, 1994, Nironen, 1997). It could also be a consequence of closure of the Svionian marginal basin under the marginal basin accretion hypothesis, since this might also involve subduction at the inboard margin. Direct evidence for the orientation of the active margin presumed to be outboard of the marginal basin to the west, or for the orientation of subduction related to it, is tenuous. $\mathrm{D}_{\mathrm{E}}$ fold trends usually have a substantial meridional component but are rather variable and affected by later deformation.

A Phanerozoic analogue for the early evolution of the Svionian basin may be provided by the Japan Sea, which was formed rapidly between 23 and $15 \mathrm{Ma}$ (e.g. Okamura et al., 1998), is some $900 \mathrm{~km}$ wide, and is only partly floored by oceanic crust. The Lachlan belt in Australia is an analogue for the basin fill and for the subsequent tectonic evolution of the Svionian Ba$\sin$. Ordovician turbidites extend right across the Lachlan belt and, with the exception of the easternmost zone, represent the fill of a marginal basin or basins that were originally more than 1000 $\mathrm{km}$ wide (e.g. Fergusson, 2003).

The subsequent history of the Lachlan belt was different in different areas and there is evidence for diachronous deformation. However, the most significant deformation of the sequence (traditionally known as the Benambran Orogeny, cf. Gray et al., 1997; VandenBurg, 1999; Collins and Hobbs, 2001; Willman et al., 2002), which closed the marginal basin, took place in the late Ordovician to early Silurian. It is comparable to the $-1.92-1.90 \mathrm{Ga}\left(\mathrm{D}_{\mathrm{E}}\right)$ deformation and metamorphism that closed the Svionian Basin in the Svecofennian province. The style of the early deformation in the crust of the Lachlan belt, including major low angle thrusts, has recently been revealed in the NE of the belt by seismic reflection studies (Glen et al., 2002). But the nature of the basement and the specific role of subduction in producing the tectonic pattern have yet to be resolved (e.g. Gray et al., 2002; Cayley et al., 2002). This emphasises that much further work is required to establish the 
histories and mutual relations of the various proposed Svionian metamorphic complexes, before plausible models of pre-1.91 Ga Svecofennian evolution can be presented. A key related question is the extent to which the main plutonic domains adjacent to the metamorphic complexes contain evidence of a pre-1.91 Ga history.

\subsection{Evidence for pre-1.9I Ga structures in the CFGC and LSGM}

Various areas of veined gneisses, similar to those in the VMB, have been mapped near to the southern and eastern boundaries of the CFGC. In the SE corner of the CFGC, Nironen (1995) reports an age of $1906 \pm 10 \mathrm{Ma}$ for a medium grained tonalite, which he considers post-dates deformation and metamorphism in older tonalite/granodiorite and in paragneisses. This age is now considered to be false because the conventional data are heterogeneous, probably due to inherited zircon (H. Huhma, pers. comm., 2004). Nevertheless, the geological relationships indicate that the older deformation and metamorphism might be the same as in the $\mathrm{VMB}$ and further work is desirable.

The late Svecofennian granite-migmatite zone (LSGM) of Ehlers et al. (1993; see Fig. 15) is a zone of high-grade metamorphism, migmatites and S-type granites dated between 1.84 and $1.80 \mathrm{Ga}$. Older tectonic relationships are therefore difficult to decipher. High-grade gneisses in the Turku district (about $50 \mathrm{~km} \mathrm{NW}$ of Kemiö township (Fig. 15) are associated with a southwesterly extension of the Hämeenlinna-Somero volcanic belt (HSB). It has been assumed that all the sequence was involved in all the deformation history so that a date of $1888 \pm 11 \mathrm{Ma}$ (Vaasjoki, 1994) from the upper part of the HSB has been considered to provide not only a minimum age for the sequence (Väisänen and Hölttä, 1999, p. 182) but also a maximum age for the onset of deformation (op. cit., p. 205). However, the close similarity of the HSB evolution to that of the TSB (see section 8.4 below), suggests that the HSB was not involved in the early deformation history. The intrusion of the potassium-rich granites of the LSGM in the Turku district is attributed to the local $\mathrm{D}_{3}$. The earlier $\mathrm{D}_{1} / \mathrm{D}_{2}$ deformations (op. cit.) in the gneisses appear to have taken place under similar metamorphic conditions and to have similar relationships to the early granitoids (here -1.89-1.87 Ga), as have been described from the VMB. There is therefore a possibility that the earliest bedding parallel biotite + sillimanite foliation (mostly obliterated by younger events, op. cit., p. 183) is a pre-1.91 Ga structure like that in the VMB.

It has been noted that the volcanic belts of SW Finland show a general transition from bimodal sequences in Enklinge-Orijärvi, through calc-alkaline associations, to more alkaline volcanics in Tampere (Ehlers \& Lindroos, 1997). Broadly the thick basaltic and andesitic sequences accompanied by thick turbiditic sequences in the TSB and HSB form a northern domain. This domain contrasts with a $100 \mathrm{~km}$ wide southern domain (Fig. 15), where a thin succession contains pillow lavas with EMORB characteristics associated with shallow marine sediments including marbles and iron formations. Ehlers \& Lindroos (op. cit.) infer extension and rifting for this southern domain, and it presumably occurred in a previously more stable tectonic environment than that of the northern domain. The nature of the basement in which this rifting occurred has not been established.

The area of bimodal volcanics south and west of Hyvinkää (Fig. 15) has been called the Kemiö-Mäntsälä Belt (KMB, e.g. Kähkönen et al., 1994) and is generally regarded as an eastward continuation of the Bergslagen ore province in Sweden, so that the felsic volcanics would be younger than $\sim 1.9 \mathrm{Ga}$ (e.g. Lindroos \& Ehlers, 1994, Fig. 1; Lundström et al., 1998). This has been confirmed in the Orijarvi area, where IDTIMS U-Pb zircon analyses from the bottom and top of the felsic succession yielded ages of $1895.3 \pm 2.4 \mathrm{Ma}$ and $1878.2 \pm 3.4 \mathrm{Ma}$ respectively (Väisänen \& Mänttäri, 2002). However, only upright folds affect these rocks, and 
primary volcanic and sedimentary features are preserved (Colley \& Vestra, 1987, p. 96). Thus the felsic sequence is similar in age and structural style to the TSB, and it seems possible that, as in the Tampere district, earlier deformation took place in underlying rock groups before the felsic volcanics were erupted. The observation that polymict breccias contain blocks of gneiss, regarded by Colley and Vestra (op. cit. p. 97) as possible Archaean basement, but which might also be pre-1.91 Ga or pre-1.98 Ga Palaeoproterozoic gneisses, offers an avenue for future research.

Furthermore, the stratigraphy of the KMB is controversial, and it has been suggested that the thin marbles with associated iron formations and cherts, referred to above, may form a marker horizon, separating two distinct rock groups (Lindroos, 1990, reported by Kähkonen et al., 1994). Thus the mafic rocks indicative of rifting (Ehlers et al., 1986) in the Nagu-Korpo area, about $40 \mathrm{~km}$ WNW of Kemiö township, (Fig. 15), may be significantly older than the dated felsic volcanics. They resemble recent withinplate lavas (cf. Haveri) and are closely associated with the Turku gneisses discussed above. Their possible correlation with the mafic volcanism in the VMB needs to be explored.

We surmise therefore, on the basis of these indications of pre-1.91 Ga structures and rock units, that the younger stage Svionian Basin may well have extended through the areas of the CFGC and LSGM. We have also suggested above (section 8.1) that both areas may be underlain by the older stage Svionian basin accreted before $-1.96 \mathrm{Ga}$. The accretion of the older and younger stage Svionian basins therefore provides a possible explanation for the older crust postulated on geochemical grounds in both of these domains (e.g. Lahtinen \& Huhma, 1997; Rämö et al., 2001). The contrast, noted above, between the northern and southern domains during the post-accretionary volcanism, also suggests that the VMB differs in crustal character from the LSGM and the CFGC. We therefore further speculate that rifting at $-1.95-1.96$ Ga may have split the older stage Svionian complex so that the younger Svionian Basin beneath the VMB may have been floored by new oceanic crust, or by older crust of much reduced thickness. This might help explain the absence of younger granites in the VMB, while they are prominent in the older crustal areas to north and south.

\subsection{The post- I.9I Ga volcanic sequences}

The volcanic sequence of the TSB indicates an extensional period between the early deformation of the $\mathrm{VMB}\left(\mathrm{VD}_{1}\right)$ and the later deformation of the TSB $\left(\mathrm{TD}_{1}\right)$ and this is well bracketed between $\sim 1.92 \mathrm{Ga}$ and $\sim 1.88 \mathrm{Ga}$ (cf. Rutland et al., 2001a, b) for the Skellefte district (SD) in Sweden. There is therefore a $40 \mathrm{~m}$.y. period, during which the TSB sequence was deposited, before the $-1.88 \mathrm{Ga}$ folding and metamorphism. There is no evidence of local subduction during this period, although subduction presumably continued beneath an active margin outboard of the closed Svionian marginal basin.

The analogous Late Silurian and Early Devonian history in the Lachlan belt in Australia is one of crustal extension producing shelves, troughs and inferred half grabens in the underlying deformed Ordovician complex (e.g. Glen et al., 2002; Willman et al., 2002) well inboard of the contemporaneous active margin. This extensional episode of about 50 m.y. corresponds to the main period of granitoid emplacement and volcanism in the belt (see e.g. Zen, 1995; Collins, 1998; Chappell et al., 2000). Thus, it occupied a similar time span to the $-1.92-1.88$ Ga extensional period of granitoid emplacement and volcanism in the TSB.

The TSB and other volcanic sequences therefore need to be re-evaluated as the preserved remnants of a widespread episode of extensional volcanism, which followed the accretion of the Svionian marginal basin. The close similarities in age and in qualitative evolution between the Skellefte (SD), Tampere (TSB) and Hämeenlinna-Somero (HSB) volcanic belts 
(Fig. 15) appear to favour the post-accretionary interpretation. In all three areas the lower parts of the sequences are characterized by felsic volcanics closely associated with greywackes and pelites and are followed by tectonic activity leading to the deposition of conglomerates containing clasts derived from the underlying sequence or from granitoids of similar age. The lower felsic volcanics in the TSB, with published ages of $1904 \pm 4 \mathrm{Ma}, 1898 \pm 4 \mathrm{Ma}$ and $1892 \pm 3$ Ma (Kähkönen et al., 1989; 2004) appear to be slightly older than the published ages of $1888.8 \pm 4.2 \mathrm{Ma}$ and $1882 \pm 8 \mathrm{Ma}$ in the SD (Billström and Weihed, 1996). In the Skellefte district, the change in depositional character has been attributed to uplift in response to relaxation of crustal extension and the emplacement of large intrusions to shallow crustal levels (Allen et al., 1996) and it is likely that this explanation has more general application.

In all three areas this tectonic activity is also followed by more mafic upper volcanic sequences, probably reflecting renewed extension. In the TSB these mafic rocks are limited to small areas in the axial depressions of the main synclinal hinge zone, and one date of $1889 \pm 5 \mathrm{Ma}$ has been obtained (Kähkönen et al., 1989). In the HSB a meta-andesite has been dated at $1888 \pm 11 \mathrm{Ma}$ (Vaasjoki, 1994). In the SD significantly younger dates of $1878 \pm 2 \mathrm{Ma}, 1876 \pm 3$ $\mathrm{Ma}$ and $1874.9 \pm 3.7 \mathrm{Ma}$ have been obtained (Skiöld et al., 1993). The available evidence indicates that the folding in the SD $(-1.86 \mathrm{Ga}$, Rutland et al., 2001b) was also somewhat later than in the TSB (1.88 Ga, Nironen, 1989b). The age of the folding is not established in the HSB but it is notable that the granitoids dated in the western areas of the HSB at $-1.87 \mathrm{Ga}$ are about 10 Ma younger than related granitoids in the CFGC and TSB (Väisänen et al., 2002).

Major upright synclines with E-W trend characterise all three areas, and the volcanic sequences were probably originally much more extensive. In the SD the younger mafic sequences are extensive to the north of the main synclinal structure, in the Vargfors and Arvidsjaur groups, where the presence of a basement domain preserving N-S trends is indicated (e.g. Rutland et al., 2001b). South-side up shears separate the SD from the pre-1.9 Ga migmatites of the Robertsfors Group to the south and a similar shear separates the TSB from the VMB. Immediately north of the TSB, the E-W deformation also affects the adjacent CFGC, where volcanics and sediments, presumably correlative with the TSB, are also preserved in the Hirsilä Belt (Fig. 15). Further north, similar volcanics again appear in the Haukkamaa area (Tiainen and Kähkönen, 1994), but NW trends dominate in remnant supracrustal belts and in the early granitoids in the intervening area, and may again be indicative of a less deformed basement domain. One of several $-\mathrm{W}$-trending belts of gabbroic intrusions locally marks the southern boundary of this domain (see Kuru 1:100 000 map sheet 2213, Matisto, 1960), suggesting a relationship to extensional structures initiated during the deposition of the TSB.

The VMB can be regarded as a major $\mathrm{TD}_{1}$ anticlinorium separating the synclinal structures containing the similar stratigraphic sequences of the TSB to the north and the HSB to the south (Fig. 15). In both cases, the main occurrence of turbiditic sediments associated with the volcanic sequences occurs adjacent to the VMB. In the HSB, Hakkarainen (1994) considered that the extensive Häme Group was erupted from an EW fissure system. Thus, it seems likely that in the TSB and HSB, as in the SD (Rutland et al., 2001a, p. 230), the post-TSB fold structures are paralleling earlier W-trending extensional or transtensional rift structures in the pre-1.91 Ga basement.

The necessary re-appraisal of the petrology and geochemistry of the volcanic sequences is beyond the scope of this paper, but the prolonged pre-1.9 Ga crustal history now proposed and the crustal thickening prior to the volcanism appear to fit well with the evolved character of the volcanics and the evidence of a pre-1.9 Ga component in both the volcanic and plutonic 1.90-1.87 Ga suites outlined in section 1 above. 
Characteristics transitional towards within-plate basalts are also sometimes present (Kähkönen, 1987, 1994; Viluksela, 1994). Possibly, arc characteristics could have been inherited from slabs subducted during the $-1.92 \mathrm{Ga}$ closure of the Svionian Basin. Certainly, the facies variation within the belts has no necessary relation to the W-trending extensional or fold structures, or to previously postulated subduction zones. For example, a N-trending zonation has been reported in the volcanic province north of the Skellefte district (Perdahl \& Fritsch, 1993) and also from the Bergslagen district (Lagerblad, 1988). We also note that some examples of calc-alkaline magmatism elsewhere are not as closely related to subduction zones in time or space as is often assumed (e.g. Chappell et al., 2000; Collins, 2002; Bryan et al., 2003).

\subsection{Concluding Comment}

The results discussed here, in conjunction with earlier work in the Skellefte region, show that the hypothesis of rapid arc-accretion post-1.9 Ga for the greater part of the Svecofennian Province can no longer be sustained. The available evidence indicates a long earlier history with two main episodes of accretion between periods of basin formation at $-2.1-1.98 \mathrm{Ga}$ (older Svionian), -1.97-1.92 Ga (younger Svionian) and -1.91-1.86 Ga (Bothnian). We suggest that the alternative hypothesis of marginal basin accretion discussed above provides a more satisfatory explanation of the main features of the Svecofennian orogenic province. The occurrence of older migmatite complexes beneath the volcanic belts is explained in terms of the younger stage Svionian marginal Basin ( $1.97-1.92$ $\mathrm{Ga}$ ), closed during the the major $-1.92 \mathrm{Ga}$ tectono-thermal event, which was responsible for the main episode of crustal thickening, probably involving pre- $1.91 \mathrm{Ga}$ subduction zones. The pattern of this Early Svecofennian orogenic phase remains to be explored, and exotic microcontinents may have been accreted at that time. However, the older crustal areas of the CFGC and LSGM might also be explained as thicker areas of the accreted older $(-2.1-1.98 \mathrm{Ga})$ stage of Svionian Basin evolution. The younger greywackes in the post- 1.91 Ga Bothnian Basin are largely the consequence of erosion of the pre$1.92 \mathrm{Ga}$ complexes.

The wide regional distribution of 1.90-1.87 Ga plutonic and volcanic rocks (extending into the Archaean basement of the Karelian Province), the exclusively HT/LP metamorphism and the extensive migmatisation all indicate a very high heat input over a wide area between 1.90 and $1.87 \mathrm{Ga}$, which is plausibly explained by the -40 m.y. extensional episode following the main episode of crustal thickening. The unusually thick and high-velocity lower crust in some areas (Korja et al., 1993), and notably beneath the CFGC, may also be largely the consequence of underplating during this extensional episode (cf. Etheridge et al., 1987; Rutland et al., 2001b). However, both the Svionian and younger extensional events may also have contributed to the underplating (e.g. at $\sim 1.8 \mathrm{Ga}$, Peltonen \& Mänttäri, 2001).

The Palaeoproterozoic north Australian orogenic province and the Palaeozoic Lachlan belt in eastern Australia are also characterised by thick high-velocity lower crust and by HT/LP metamorphism and abundant granitoids (e.g. Rutland, 1982, 1997). The strong similarities in tectonic evolution between the Svecofennian Province and the Lachlan belt suggest that they developed in similar tectonic settings.

\section{Acknowledgments}

We thank Hannu Huhma and Mikko Nironen for constructive reviews that resulted in major improvements in the manuscript. Williams and Rutland would like to acknowledge their debt to numerous Finnish geologists, and especially to co-author Korsman, who have helped them develop some, albeit imperfect, understanding of Finnish Precambrian geology, both in the field and through the exceptionally comprehensive body of literature that is available. Particular thanks are due to Timo Kilpeläinen whose work provided the essential basis for this study and who has assisted throughout; and to, Carl Ehlers, Gabor Gaál, Asko Kontinen, Tapio Koistinen, Jukka Kousa, Raimo 
Lahtinen and Mikko Nironen. We thank Shane Paxton and John Mya for their careful preparation of the zircon and monazite separates; Dr Sally Stowe, Dr Roger Heady, and the staff of the ANU Electron Microscopy Unit for assistance with SEM cathodoluminescence and backscattered electron imaging; and Brad Ferguson, Maija Kurimo, Angie Jaensch and Joe Mifsud for assistance with the figures. The work began as a contribution to the work of the Australian Geodynamics Cooperative Research Centre, whose support is also gratefully acknowledged.

\section{Editorial handling: Petri Peltonen}

\section{References}

Andersen, T. \& Sundvoll, B., 1995. Neodymium isotope systematics of the mantle beneath the Baltic shield: Evidence for depleted mantle since the Archaean. Lithos 35, 235-243.

BABEL Working Group, 1990. Evidence for Early Proterozoic plate tectonics from seismic reflection profiles in the Baltic shield. Nature 348, 34-38.

BABEL Working Group, 1993. Integrated seismic studies of the Baltic Shield using data in the Gulf of Bothnia region. Geophysical Journal International 112, 305-324.

Billström K. \& Weihed, P., 1996. Age and provenance of host rocks and ores in the Palaeoproterozoic Skellefte District, northern Sweden. Economic Geology 91, 1054-1072.

Bogdanova, S. \& Eurobridge colleagues, 1996. Eurobridge: Palaeoproterozoic accretion of Sarmatia and Fennoscandia. In: Gee, D.G. \& Zeyen, H.J. (eds.) Europrobe, 1996 - Lithosphere Dynamics: Origin and Evolution of Continents, Published by the Europrobe Secretariate, Uppsala University, p.81-86.

Bridgwater, D., Scott, J.D., Balagansky, V.V., Timmermann, M.J., Marker, M., Bushmin, S.A., Alexeyev, N.L. \& Daly, J.S., 2001. Age and provenance of early Precambrian metasedimentary rocks in the LaplandKola Belt, Russia: evidence from $\mathrm{Pb}$ and $\mathrm{Nd}$ isotopic data. Terra Nova 13, 32-37.

Bryan, S.E., Holcombe, R.J. \& Fielding, C.R., 2003. Reply to discussion. Yarrol terrane of the northern New England Fold Belt: forearc or backarc? Australian Journal of Earth Sciences 50, 271-293.

Chappell, B.W., White, A.J.R., Williams, I.S., Wyborn, D. \& Wyborn, L.A.I., 2000. Lachlan Fold Belt granites revisited: high- and low-temperature granites and their implications. Australian Journal of Earth Sciences 47, 123-138.

Claesson, S., Huhma, H., Kinny, P.D. \& Williams, I. S., 1993. Svecofennian detrital zircon ages - implications for the Precambrian evolution of the Baltic Shield. Precambrian Research 64, 109-130.

Claesson, S. \& Lundqvist, T., 1995. Origins and ages of Proterozoic granitoids in the Bothnian Basin, central Sweden: isotopic and geochemical constraints. Lithos 36, 115-140.

Claesson, S., Bogdanova, S.V., Bibikova, E.V. \& Gorbatschev, R., 2001. Isotopic evidence for Palaeoproterozoic accretion in the basement of the East European Craton. Tectonophysics 339, 1-18.
Claoué-Long, J. C., Compston, W., Roberts, J. \& Fanning, C. M., 1995. Two Carboniferous ages: A comparison of SHRIMP zircon dating with conventional zircon ages and ${ }^{40} \mathrm{Ar} /{ }^{39} \mathrm{Ar}$ analysis. In: Berggren W.A., Kent D.V., Aubrey M-P. \& Hardenbol J. (eds.) Geochronology, Time Scales and Global Stratigraphic Correlation, SEPM (Society for Sedimentary Geology) Special Publication 4, 3-21.

Collins, W. J., 1998. Evaluation of petrogenetic models for Lachlan Fold Belt granitoids: implications for crustal architecture and tectonic models. Australian Journal of Earth Sciences 45, 483-500.

Collins, W. J., 2002. Hot orogens, tectonic switching, and creation of continental crust. Geology 30, 535-538.

Collins, W. J. \& Hobbs, B. E., 2001. What caused the Early Silurian change from mafic to silicic (S-type) magmatism in the eastern Lachlan Fold Belt? Australian Journal of Earth Sciences 48, 25-41.

Daly, J.S., Balagansky, V.V., Timmermann, M.J., Whitehouse, M.J., de Jong, K., Guise, P., Bogdanova, S., Gorbatschev, R. \& Bridgwater, D., 2001. Ion microprobe $\mathrm{U}-\mathrm{Pb}$ zircon geochronology and isotopic evidence for a trans-crustal suture in the Lapland-Kola Orogen, northern Fennoscandian Shield. Precambrian Research 105, 289-314.

Ehlers, C., Lindroos, A. \& Jaanus-Järkkalä, M., 1986. Stratigraphy and geochemistry in the Proterozoic mafic volcanic rocks of the Nagu-Korpo area, SW Finland. Precambrian Research 32, 297-315.

Ehlers, C., Lindroos, A. \& Selonen, O., 1993. The late Svecofennian granite-migmatite zone of southern Finland - a belt of transpressive deformation and granite emplacement. Precambrian Research 64, 295-309.

Ehlers, C. \& Lindroos, A., 1997. Stratigraphy and structural evolution of the early Proterozoic Svecofennian rocks of south Finland. In: Palaeoproterozoic Tectonics and Metallogenesis: Comparative analysis of parts of the Australian and Fennoscandian Shields. Australian Geological Survey Organisation Record 1997/44, 43-45.

Ekdahl, E., 1993. Early Proterozoic Karelian and Svecofennian Formations and the evolution of the Raahe-Ladoga ore zone, based on the Pielavesi Area, central Finland. Geological Survey of Finland, Bulletin $373,137 \mathrm{p}$.

Fergusson, C.L., 2003. Ordovician-Silurian accretion tectonics of the Lachlan Fold Belt, southeastern Australia. Australian Journal of Earth Sciences 50, 475-490.

Gaál, G. \& Gorbatschev, R., 1987. An outline of the Precambrian evolution of the Baltic Shield. Precambrian Research 35, 15-52.

Glen, R.A., Korsch, R.J., Direen, N.G., Jones, L.E.A., Johnstone, D.W., Lawrie, K.C., Finlayson, D.M. \& Shaw, R.D., 2002. Crustal structure of the Ordovician Macquarie Arc, Eastern Lachlan Orogen, based on seismic reflection profiling. Australian Journal of Earth Sciences 49, 323-348.

Gorbatschev, R. \& Bogdanova, S., 1993. Frontiers in the Baltic Shield. Precambrian Research 64, 3-22.

Götze, H. J. \& Pavlenkova, N. (eds.) Plate Tectonic Signatures in the Continental Lithosphere. Tectonophysics 219, 129-152.

Gray, D.R., Foster, D.A. \& Bucher, M.,1997. Recognition and definition of orogenic events in the Lachlan Fold Belt. Australian Journal of Earth Sciences 44, 489-501. 
Gray, D.R., Foster, D.A. \& Bierlein, F.P., 2002. Geodynamics and metallogeny of the Lachlan Orogen. Australian Journal of Earth Sciences 49, 1041-1056.

Hakkarainen, G. 1994. Geology and geochemistry of the Hämeenlinna-Somero volcanic belt, southwestern Finland; a Paleoproterozoic island arc. In: Nironen M. \& Kähkönen, Y. (eds.) Geochemistry of Proterozoic supracrustal rocks in Finland. Geological Survey of Finland, Special Paper 19, 85-100.

Heaman, L. M., Bowins, R. \& Crocket, J., 1990. The chemical composition of igneous zircon suites: implications for geochemical tracer studies. Geochimica et Cosmochimica Acta 54, 1597-1607.

Hietanen, A., 1975. Generation of potassium-poor magmas in the northern Sierra Nevada and the Svecofennian of Finland. U.S. Geological Survey, Journal of Research 3, 611-645.

Huhma, A., Salli, I. \& Matisto, A., 1952. Ikaalinen. Geological map of Finland 1:100 000, pre-Quaternary rocks, sheet 2122, Geological Survey of Finland.

Huhma, H., 1986. Sm-Nd, U-Pb and $\mathrm{Pb}-\mathrm{Pb}$ isotopic evidence for the origin of the Early Proterozoic Svecokarelian crust in Finland. Geological Survey of Finland, Bulletin 337, 52 p.

Huhma, H., Claesson, S., Kinny, P.D. \& Williams, I.S., 1991. The growth of Early Proterozoic crust: new evidence from Svecofennian detrital zircons. Terra Nova $3,175-178$.

Kähkönen, Y., 1987. Geochemistry and tectonomagmatic affinities of of the metavolcanic rocks of the early Proterozoic Tampere Schist Belt, southern Finland. Precambrian Research 35, 295-311.

Kähkönen, Y., 1994. Shoshonitic and High-K metavolcanic rocks in the southern parts of the Paleoproterozoic Tampere Schist Belt, southern Finland: Evidence for an evolved arc-type setting. In: Nironen M. \& Kähkönen, Y. (eds.) Geochemistry of Proterozoic supracrustal rocks in Finland. Geological Survey of Finland, Special Paper 19, 101-115.

Kähkönen, Y., 1996. Stratigraphy and evolution of the Palaeoproterozoic supracrustal rocks in the Tampere area, southern Finland: a preliminary review. In: Ekdahl, E. and Autio, S. (eds.) Global Geoscience Transect/SVEKA - Proceedings of the Kuopio Seminar, Finland, 25.-26.11.1993. Geological Survey of Finland, Report of Investigation 136, 9-12.

Kähkönen, Y., 1999. Stratigraphy of the central parts of the Palaeoproterozoic Tampere Schist Belt, southern Finland: review and revision. Bulletin of the Geological Society of Finland 71, 13-29.

Kähkönen, Y., Huhma, H. \& Aro, K., 1989. U-Pb zircon ages and Rb-Sr whole-rock isotope studies of early Proterozoic volcanic and plutonic rocks near Tampere, southern Finland. Precambrian Research 45, 27-43.

Kähkönen, Y. \& Huhma H., 1993. An Archaean cobble in a Svecofennian conglomerate near Tampere, southern Finland. In: Autio, S. (ed.) Current Research 1991-1992. Geological Survey of Finland, Special Paper 18, 31-36.

Kähkönen, Y. \& Leveinen, J., 1994. Geochemistry of metasedimentary rocks of the Paleoproterozoic Tampere Schist Belt, southern Finland. In: Nironen M. and Kähkönen, Y. (eds.) Geochemistry of Proterozoic supracrustal rocks in Finland. Geological Survey of Finland, Special Paper 19, 117-136.
Kähkönen, Y., Lahtinen, R. \& Nironen, M., 1994. Palaeoproterozoic supracrustal belts in southwestern Finland. Geological Survey of Finland, Guide 37, 43-47.

Kähkönen, Y. \& Nironen, M., 1994. Supracrustal Rocks around the Paleoproterozoic Haveri Au-Cu Deposit, southern Finland; Evolution from a spreading centre to a volcanic arc environment. In: Nironen $M$. and Kähkönen, Y. (eds.) Geochemistry of Proterozoic supracrustal rocks in Finland. Geological Survey of Finland, Special Paper 19, 141-159.

Kähkönen, Y., Huhma, H. \& Mänttäri, I., 2004. TIMS and SIMS U-Pb zircon ages on metavolcanic rocks from central parts of the Paleoproterozoic Tampere belt, Finland. GFF 26, p. 25.

Kilpeläinen, T., 1998. Evolution and 3D modelling of structural and metamorphic patterns of the Palaeoproterozoic crust in the Tampere-Vammala area, southern Finland. Geological Survey of Finland, Bulletin 397, $124 \mathrm{p}$.

Kilpeläinen, T., Korikovsky, S., Korsman, K. \& Nironen, M., 1994. Tectono-metamorphic evolution in the Tampere-Vammala area. In: Pajunen, M. (ed.) High temperature-low pressure metamorphism and deep crustal structures. Geological Survey of Finland, Guide 37, 27-34.

Kingsbury, J.A., Miller, C.F., Wooden, J.L. \& Harrison, T.M., 1993. Monazite paragenesis and U-Pb systematics in rocks of the eastern Mojave Desert, California U.S.A.: implications for thermochronometry. Chemical Geology 110, 147-167.

Kohonen, J., 1995. From continental rifting to collisional crustal shortening - Paleoproterozoic Kaleva metasediments of the Höytiäinen area in North Karelia, Finland. Geological Survey of Finland, Bulletin $380,79 \mathrm{p}$

Koistinen, T., Klein, B., Koppelmaa, H., Korsman, K. Lahtinen, R., Nironen, M., Puura, V., Saltykova, T., Tikhomirov, S. \& Yanovskiy, A., 1996. Paleoproterozoic Svecofennnian orogenic belt. In: Koistinen, T. (ed.) Explanation to the map of Precambrian basement of the Gulf of Finland and surrounding area 1: 1 million. Geological Survey of Finland, Special Paper 21, 21-57.

Korja, A., Korja, T., Luosto, U. \& Heikkinen P., 1993. Seismic and geoelectric evidence for collisional and extensional events in the Fennoscandian Shield -implications for Precambrian crustal evolution. In: Green, K. G., Kröner, A., Götze, H. J., and Pavlenkova, N. (eds.) Plate Tectonic Signatures in the Continental Lithosphere. Tectonophysics 219, 129-152.

Korsman, K., Niemelä, R. \& Wasenius, P., 1988. Multistage evolution of the Proterozoic crust in the Savo schist belt, eastern Finland. Geological Survey of Finland, Bulletin 343, 89-96.

Korsman, K. \& Korja, T., 1994. Preface. In: Pajunen, M. (ed.) High temperature-low pressure metamorphism and deep crustal structures. Geological Survey of Finland, Guide 37, 5-6.

Korsman, K., Korja, T., Pajunen, M., Virransalo, P. \& GGT/SVEKA Working Group, 1999. The GGT/ SVEKA Transect: Structure and evolution of the continental crust of the Palaeoproterozoic Svecofennian Orogen in Finland. International Geology Review 41, 287-333. 
Korsman, K., Koistinen, T., Kohonen, J., Wennerström, M., Ekdahl, E., Honkamo, M., Idman, H. \& Pekkela, Y. (eds.) 1997. Bedrock map of Finland, 1:1 000 000. Geological Survey of Finland.

Lagerblad, B., 1988. Evolution and tectonic history of the Bergslagen volcano-plutonic Complex, Central Sweden. Geologie en Mijnbouw 67, 165-176.

Lahtinen, R., 1994. Crustal evolution of the Svecofennian and Karelian domains during 2.1-1.79 Ga, with special emphasis on the geochemistry and origin of 1.93 $1.91 \mathrm{Ga}$ gneissic tonalites and associated supracrustal rocks in the Rautalampi area, central Finland. Geological Survey of Finland, Bulletin 378, 128 p.

Lahtinen, R., 1996. Geochemistry of Palaeoproterozoic supracrustal and plutonic rocks in the TampereHämeenlinna area, southern Finland. Geological Survey of Finland, Bulletin 389, 113 p.

Lahtinen, R. \& Huhma, H., 1997. Isotopic and geochemical constraints on the evolution of the 1.93-1.97 Ga Svecofennian crust and mantle in Finland. Precambrian Research 82, 13-34.

Lahtinen, R., Huhma, H. \& Kousa, J., 2002. Contrasting source components of the Palaeoproterozoic Svecofennian metasediments: Detrital zircon U-Pb, Sm$\mathrm{Nd}$ and geochemical data. Precambrian Research 116, 81-109.

Lindroos, A. \& Ehlers, C., 1994. Emplacement, deformation and geochemistry of bimodal volcanics in Vestlax, SW Finland. In: Nironen M. and Kähkönen, Y. (eds.) Geochemistry of Proterozoic supracrustal rocks in Finland. Geological Survey of Finland, Special Paper 19, 173-184.

Lindroos, A., Romer, R.L., Ehlers, C. \& Alviola, R., 1996. Late-orogenic Svecofennian deformation in SW Finland constrained by pegmatite emplacement ages. Terra Nova 8, 567-574.

Ludvig, K. R., 2001. User's manual for Isoplot/Ex, rev. 2.49, A geochronological toolkit for Microsoft Excel. Berkeley Geochronology Center Special Publication 1a, Berkeley CA, 59 p.

Lundqvist, T., Vaasjoki, M. \& Persson, P-O., 1998. U-Pb ages of plutonic and volcanic rocks in the Svecofennian Bothnian Basin, central Sweden, and their implications for the Palaeoproterozoic evolution of the Basin. Geologiska Föreningens i Stockholm Förhandlingar 120, 357-363.

Lundström, I., Allen, R., Persson, P-O. \& Ripa, M., 1998. Stratigraphies and depositional ages of Svecofennian, Palaeoproterozoic rocks in E. Svealand and Bergslagen, south central Sweden. Geologiska Föreningens i Stockholm Förhandlingar 120, 315-320.

Matisto, A., 1960. Kuru. Geological map of Finland 1: 100 000, pre-Quaternary rocks, sheet 2213, Geological Survey of Finland.

Matisto, A., 1967. Vammala. Geological map of Finland 1:100 000, pre-Quaternary rocks, sheet 2121 , Geological Survey of Finland.

Matisto, A., 1973. Toijala. Geological map of Finland 1: 100 000, pre-Quaternary rocks, sheet 2114, Geological Survey of Finland.

Mouri, H., Korsman, K. \& Huhma, H., 1999. Tectono-metamorphic evolution and timing of the melting processes in the Svecofennian tonalite-trondhjemite migmatite Belt: an example from Luopioinen, Tampere area, southern Finland. Bulletin of the Geological Society of Finland 71, 31-56.
Nironen, M., 1989a. The Tampere Schist Belt: Structural style within an Early Proterozoic volcanic arc system in southwestern Finland. Precambrian Research 4, 23-40.

Nironen, M., 1989b. Emplacement and structural setting of granitoids in the Early Proterozoic Tampere and Savo schist belts, Finland - implications for contrasting crustal evolution. Geological Survey of Finland, Bulletin 346, 83 p.

Nironen, M., 1995. Block boundary at the southeastern margin of the Palaeoproterozoic Central Finland Granitoid Complex. Geological Survey of Finland, Bulletin 382, 91-115.

Nironen, M., 1997. The Svecofennian Orogen: a tectonic model. Precambrian Research 86, 21-44.

Nironen M. \& Kähkönen, Y. (eds.), 1994. Geochemistry of Proterozoic Supracrustal Rocks in Finland. Geological Survey of Finland, Special Paper 19, 184 p.

Nironen, M., Elliott, B. A. \& Rämö, O. T., 2000. 1.88$1.87 \mathrm{Ga}$ post-kinematic intrusions of the Central Finland Granitoid Complex: a shift from C-type to Atype magmatism during lithospheric convergence. Lithos 53, 37-58.

Nironen, M., Lahtinen, R. \& Koistinen, T, 2002. Subdivision of Finnish bedrock - an attempt to harmonise terminology. Geologi 54, 11-14.

Okamura, S., Arculus, R. J., Martynov, Y. A., Kagami, H., Yoshida, T. \& Kawano, Y., 1998. Multiple magma sources involved in marginal-sea formation: $\mathrm{Pb}$, $\mathrm{Sr}$, and $\mathrm{Nd}$ isotopic evidence from the Japan Sea region. Geology 26, 619-622.

Park, A. F., 1985. Accretion tectonism in the Proterozoic Svecokarelides of the Baltic Shield. Geology 13, 725-729.

Patchett, P. J. \& Arndt, N. T., 1986. Nd Isotopes and Tectonics of 1.9 - 1.7 Ga Crustal Genesis. Earth and Planetary Science Letters 78, 329-338.

Peltonen, P. \& Mänttäri, I., 2001. An ion microprobe U$\mathrm{Th}-\mathrm{Pb}$ study of zircon xenocrysts from the Lahtojoki kimberlite pipe, eastern Finland. Bulletin of the Geological Society of Finland 73, 47-58.

Perdahl, J-A. \& Frietsch, R., 1993. Petrochemical and petrological characteristics of 1.9 Ga old volcanics in northern Sweden. Precambrian Research 64, 239-252.

Puura, V. \& Huhma, H., 1993. Palaeoproterozoic age of the East Baltic granulitic crust. Precambrian Research 64, 289-294.

Rämö, O.T., Vaasjoki, M., Mänttäri, I., Elliott, B. A. \& Nironen, M., 2001. Petrogenesis of the post-kinematic magmatism of the Central Finland Granitoid Complex I; Radiogenic isotope constraints and implications for crustal evolution. Journal of Petrology 42, 1971-1993.

Rutland, R.W.R., 1982. On the growth and evolution of continental crust: a comparative tectonic approach. W.B. Clarke Memorial Lecture, Royal Society of New South Wales, 115, 33-60.

Rutland, R.W.R., 1997. Palaeoproterozoic of northern Australia and Fennoscandia: an introduction. In: Palaeoproterozoic Tectonics and Metallogenesis: Comparative analysis of parts of the Australian and Fennoscandian Shields. Australian Geological Survey Organisation Record, 1997/44, 1-5.

Rutland, R.W.R., Kero, L., Nilsson, G. \& Stølen, L.K, 2001a. Nature of a major tectonic discontinuity in the Svecofennian province of northern Sweden. Precambrian Research 112, 211-237. 
Rutland, R.W.R., Skiöld, T. \& Page, R.W., 2001b. Age of deformation episodes in the Palaeoproterozoic domain of northern Sweden, and evidence of a pre-1.9 Ga crustal layer. Precambrian Research 112, 239-259.

Sederholm, J.J., 1897. Über eine archäische Sedimentformation im Südwestlichen Finnland und ihre Bedeutung für die Erklärung der Entstehungsweise des Grundgebirges. Bulletin de la Commission géologique de Finlande 6, $254 \mathrm{p}$.

Sederholm, J.J., 1931. On the Sub-Bothnian unconformity and on Archaean rocks formed by secular weathering. Bulletin de la Commission géologique de Finlande $95,81 \mathrm{p}$.

Simonen, A., 1953. Stratigraphy and sedimentation of the Svecofennidic, early Archaean supracrustal rocks in southwestern Finland. Bulletin de la Commission géologique de Finlande, 160, 64 p.

Simonen, A., 1980. The Precambrian of Finland. Geological Survey of Finland, Bulletin 304, 58 p.

Skiöld, T.B., Öhlander, B., Markkula, H., Widenfalk, L. \& Claesson, L-Å., 1993. Chronology of Proterozoic orogenic processes at the Archaean continental margin in northern Sweden. Precambrian Research 64, 225-238.

Steiger, R.H. \& Jäger, E., 1977. Subcommission on geochronology: convention on the use of decay constants in geo- and cosmochronology. Earth and Planetary Science Letters 36, 359-362.

Tiainen, M. \& Kähkönen, Y., 1994. Geochemistry of the Palaeoproterozoic andesitic to rhyolitic arc-type metavolcanic rocks of Haukkamaa, Kuru, central Finland. In: Nironen M. \& Kähkönen, Y. (eds.) Geochemistry of Proterozoic supracrustal rocks in Finland. Geological Survey of Finland, Special Paper 19, 29-45.

Vaasjoki, M., 1994. Valijärven hapan vulkaniitti: minimi Hämeen liuskejakson iäksi. Summary: Radiometric age of a meta-andesite at Valijärvi, Häme schist zone, southern Finland. Geologi 46, 91-92.

Vaasjoki, M. \& Huhma, H., 1999. Lead and neodymium isotopic results from metabasalts of the Haveri Formation, southern Finland: evidence for Palaeoproterozoic enriched mantle. Bulletin of the Geological Society of Finland 71, 145-153.

Väisänen, M. \& Hölttä, P., 1999. Structural and metamorphic evolution of the Turku migmatite complex, southwestern Finland. Bulletin of the Geological Society of Finland 71, 177-218.

Väisänen, M., Mänttäri, I., Kriegsman, L. M. \& Hölttä, P., 2000. Tectonic setting of post-collisional magmatism in the Palaeoproterozoic Svecofennian Orogen, SW Finland. Lithos 54, 63-81.

Väisänen, M. \& Mänttäri, I., 2002. 1.90-1.88 Ga arc and back-arc basin in the Orijärvi area SW Finland. Bulletin of the Geological Society of Finland 74, 185-214.

Väisänen, M., Mänttäri, I. \& Hölttä, P., 2002. Svecofennian magmatic and metamorphic evolution in southwestern Finland as revealed by U-Pb zircon SIMS geochronology. Precambrian Research 116, 111-127.
Valbracht, P.J., Oen, I.S. \& Beunk, F.F., 1994. Sm-Nd isotope systematics of 1.9-1.8 Ga granites from western Bergslagen, Sweden: inferences on a 2.1-2.0 Ga crustal precursor. Chemical Geology 112, 21-37.

VandenBurg, A. H. M., 1999. Timing of orogenic events in the Lachlan Orgen. Australian Journal of Earth Sciences 46, 691-701.

Viluksela, A., 1994. Geochemistry of calc-alkaline metavolcanic rocks in the Parikkala-Punkaharju area southeastern Finland. In: Nironen M. \& Kähkönen, Y. (eds.) Geochemistry of Proterozoic supracrustal rocks in Finland. Geological Survey of Finland, Special Paper 19, 61-69.

Virransalo, P. \& Vaarma, M., 1993. Ikaalinen. Geological map of Finland 1:100 000, pre-Quaternary rocks, sheet 2114, Geological Survey of Finland.

Wasström, A., 1993. The Knaften granitoids of Vasterbotten County, northern Sweden. In: Lundqvist, T. (ed.) Radiometric dating results. Geological Survey of Sweden, series C,. 823, 60-64.

Wasström, A., 1996. U-Pb zircon dating of a quartz-feldspar porphyritic dyke in the Knaften area, Västerbotten County, northern Sweden. In: Lundqvist, T. (ed.) Radiometric dating results 2. Geological Survey of Sweden, series C, 828, 34-40.

Welin, E., Christansson, K. \& Kähr, A-M., 1993. Isotopic investigations of metasedimentary and igneous rocks in the Palaeoproterozoic Bothnian Basin, central Sweden. Geologiska Föreningens i Stockholm Förhandlingar 115, 285-296.

Williams, I. S., 2001. Response of detrital zircon and monazite, and their $\mathrm{U}-\mathrm{Pb}$ isotopic systems, to regional metamorphism and host-rock partial melting, Cooma Complex, southeastern Australia. Australian Journal of Earth Sciences 48, 557-580.

Williams, I. S. \& Claesson, S., 1987. Isotopic evidence for the provenance and Caledonian metamorphism of high-grade paragneisses from the Seve Nappes, Scandinavian Caledonides. Ion microprobe zircon U-Th$\mathrm{Pb}$. Contributions to Mineralogy and Petrology 97, 205-217.

Williams, I. S., Buick, I. S. \& Cartwright, I., 1996. An extended episode of early Mesoproterozoic metamorphic fluid flow in the Reynolds Range, central Australia. Journal of Metamorphic Geology 14, 29-47.

Willman, C. E., VandenBurg, A. H. M. \& Morand, V. J., 2002. Evolution of the southeastern Lachlan Fold Belt in Victoria. Australian Journal of Earth Sciences 49, 271-289.

Zen, E-an, 1995. Crustal magma generation and LP/HT regional metamorphism in an extensional environment; possible application to the Lachlan Belt, Australia. American Journal of Science 295, 851-874. 